UNIVERSIDADE DE BRASÍLIA - UNB

INSTITUTO DE GEOCIÊNCIAS - IG

Programa de Pós-Graduação em Geologia

\title{
CARACTERIZAÇÃO MINERALÓGICA, GEOQUÍMICA E POTENCIAL ECONÔMICO DE OCORRÊNCIAS DE TERRAS RARAS DO MACIÇO GRANÍTICO SERRA DO MENDES, GOIÁS.
}

DISSERTAÇÃO DE MESTRADO № 390

Angélica María Zapata Montoya

Brasília - DF, 10 de março de 2017 
UNIVERSIDADE DE BRASÍLIA - UNB

INSTITUTO DE GEOCIÊNCIAS - IG

Programa de Pós-Graduação em Geologia

\section{CARACTERIZAÇÃO MINERALÓGICA, GEOQUÍMICA E POTENCIAL ECONÔMICO DE OCORRÊNCIAS DE TERRAS RARAS DO MACIÇO GRANÍTICO SERRA DO MENDES, GOIÁS.}

Angélica María Zapata Montoya

Área de Concentração: Prospecção e Geologia Econômica

Orientador:

Prof. Dr. Nilson Francisquini Botelho

Banca examinadora:

Prof. Dr. Vitor Paulo Pereira (UFRGS)

Prof. Dr. Valmir da Silva Souza (UnB)

Brasília - DF, 10 de março de 2017 


\section{AGRADECIMENTOS}

Primeiramente gostaria de agradecer a Deus e a toda minha família na Colômbia, especialmente a minha mãe Clara Luz e meu esposo Rafael.

Agradeço ao meu orientador Nilson Francisquini Botelho pela oportunidade oferecida e por sua paciência, dedicação e apoio ao longo de todo o projeto.

A todos meus amigos do Instituto de Geociências, especialmente ao Eduardo, Pedro, Alanna e Carol por me brindar com sua amizade e apoio nestes 2 anos. Ao Felipe Velásquez e Carlos Moreno, amigos de vida e companheiros incansáveis de luta.

Á CAPES, Coordenação de Aperfeiçoamento de Pessoal de Nível Superior, por todo o suporte financeiro prestado aos meus estudos e meu projeto.

Agradeço infinitamente a todo o pessoal dos laboratórios do Instituto de Geociências da Universidade de Brasília pelo apoio prestado durante este processo

Eternamente agradecida ao povo Brasileiro por me acolher tão bem em seu lindo país. 


\section{SUMÁRIO}

RESUMO

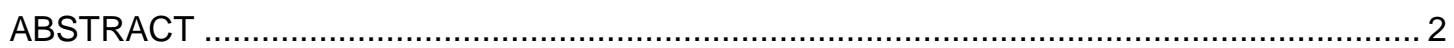

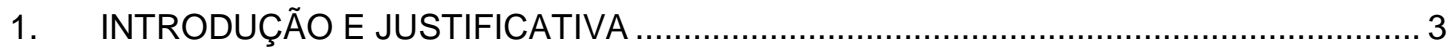

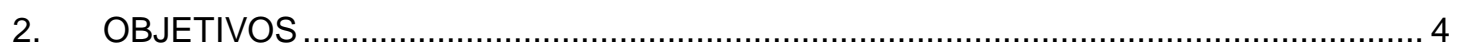

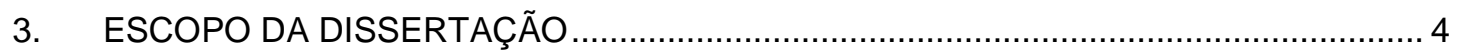

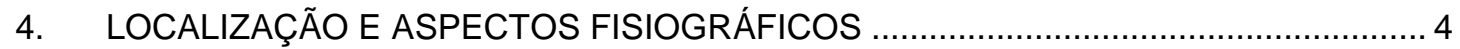

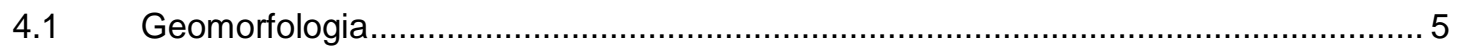

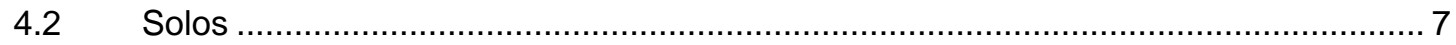

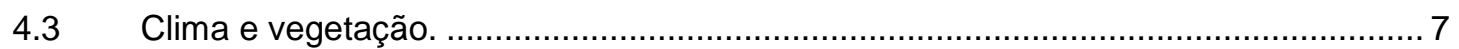

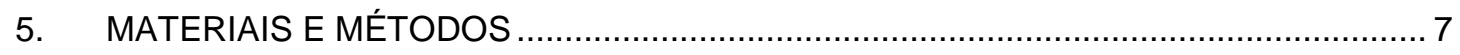

6. CONTEXTO GEOLÓGICO DA ÁREA DE PESQUISA................................................ 9

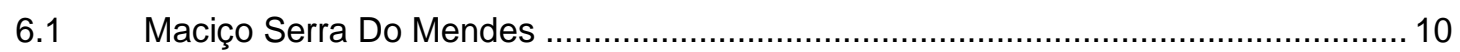

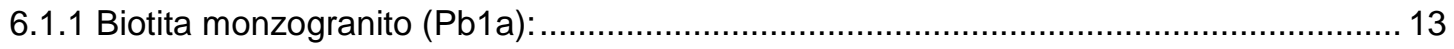

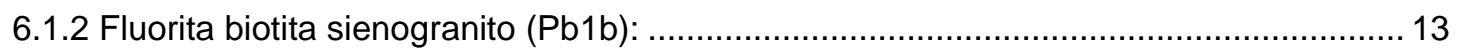

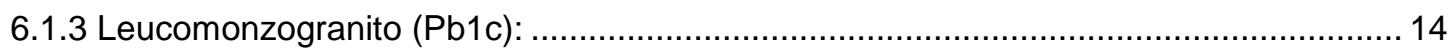

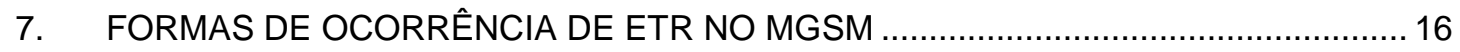

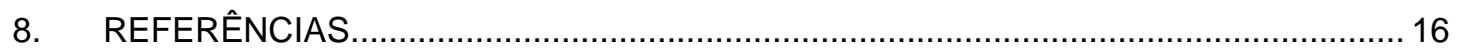

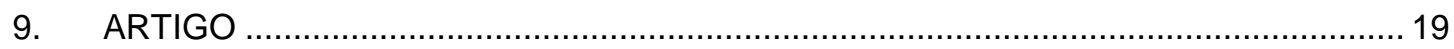

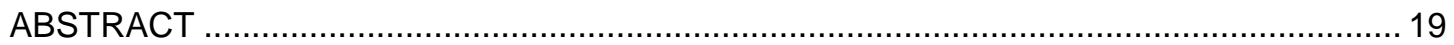

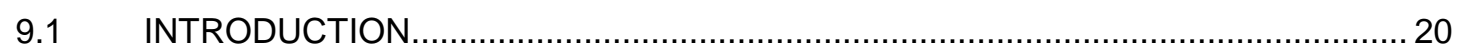

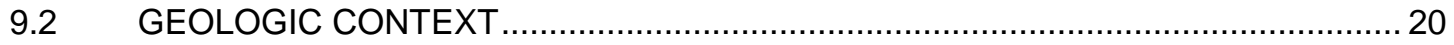

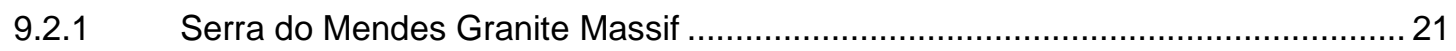

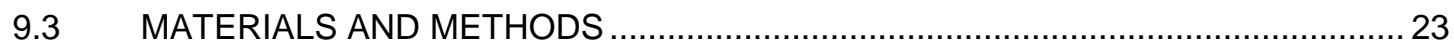

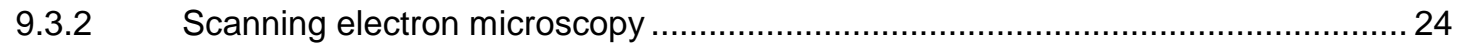

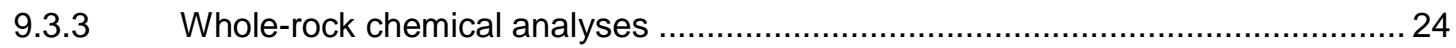

9.4 RESULTS

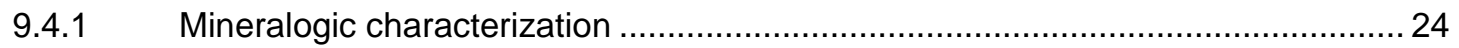

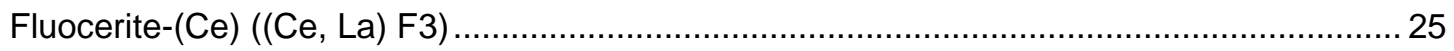

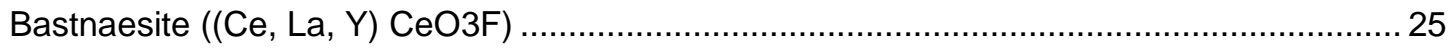




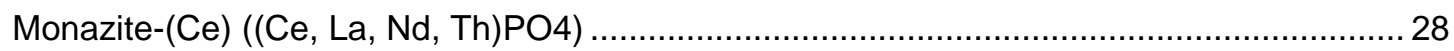

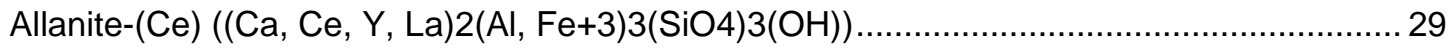

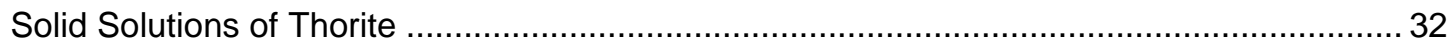

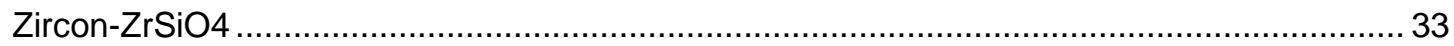

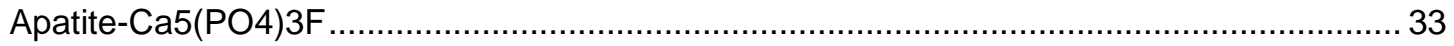

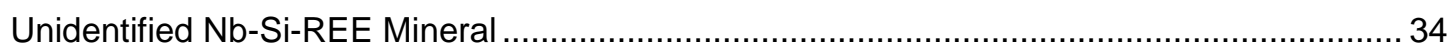

9.4.2 Geochemistry of REE in granites, saprolites and alluvial sediments ...................... 34

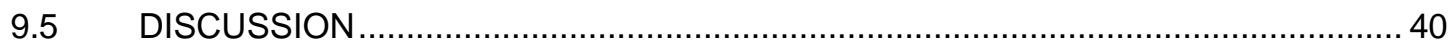

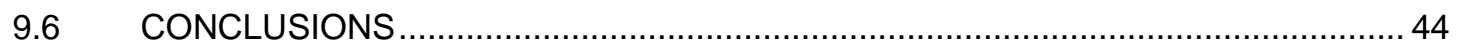

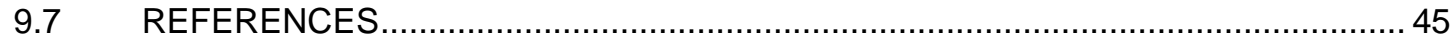

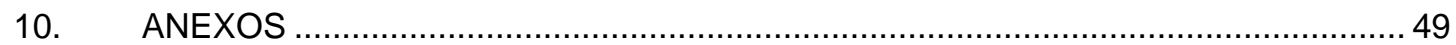

10.1 QUÍMICA MINERAL PARA FLUOCERITAS ..................................................... 49

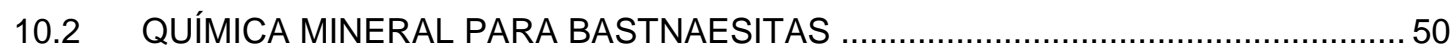

10.3 QUÍMICA MINERAL PARA OXIFLUORETOS DE ETR ….................................. 51

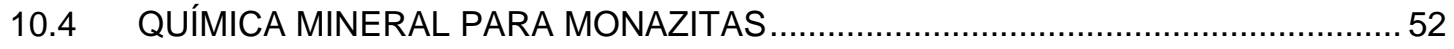

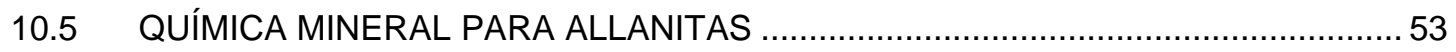

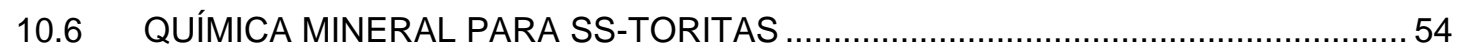

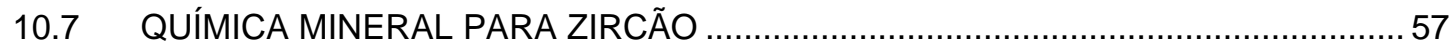

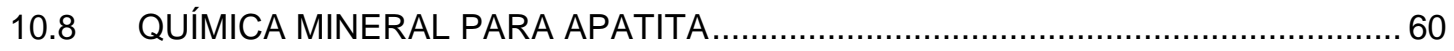

10.9 QUÍMICA MINERAL PARA MINERAL NÃO IDENTIFICADO …................................61

\section{LISTA DE FIGURAS}

Figura 1. Localização da área estudada e principais acessos.

Figura 2. Mapa geomorfológico da área estudada. Fonte: Sistema Estadual de Estatística e Informações Geográficas do Estado de Goiás-Superintendência de Geologia e Mineração.

Figura 3. Mapa com os principais maciços graníticos com potencial para ETR na PEG, com localização do Maciço Serra do Mendes (Botelho, 2013).

Figura 4. Mapa geológico do Maciço Serra do Mendes e adjacências. Adaptado de Miranda \& Ribas (2006) e Castanheira \& Andrade (2006). .12 
Figura 5. Fotomicrografias do biotita monzogranito. $a(P / /)$ e $b(P X)$ : amostra $A Z M E-8 B$ com textura granofírica preservada. $c(P / /)$ e $d(P X)$ : amostra AZME-01 com marcada foliação, onde se observa, quartzo e microclínio deformados.(Qz: quartzo; Fsp: microclínio; Bt: biotita) .13

Figura 6. Fotomicrografias do fluorita biotita sienogranito (amostra TF171B), $a(P / /)$ e $b(P X)$ : textura e associação mineral típicas da rocha; $c(P / /)$ e $d(P X)$ : Textura granofírica preservada. (Qz: quartzo; Fsp: microclínio; Ab; albita; Fl: fluorita) .14

Figura 7. Características representativas do leucomonzogranito (fácies PB1c) no MGSM. $a(P / /)$ e $b(P X)$ : Amostra ME-10A com mineralogia típica. $c(P / /)$ e $d(P X)$ : Muscovita com orientação incipiente na amostra AZME-04D 15

Figura 8. Gráfico de Streckeisen (1974) para classificação modal de rochas plutônicas, com amostras das diferentes fácies graníticas do MGSM.

Figure 9. a) Schematic geological map of the northern part of the Goiás Tin Province, with the main granitic massifs with potential for REE and location of the SMGM (modified from Botelho and Moura (1998); b) local geological map and sampling locations in the SMGM (adapted from Alvarenga et al. 2007); c) schematic section A-A '. .22

Figure 10. Optical and backscattered electron images (BSE) of REE bearing minerals from the SMGM. a) and b): fluocerite (Flc) associated with fluorite ( $F)$ and zircon ( $\mathrm{Zrn}$ ) in the leucomonzogranite (sample AZME-4B); c) and d) Bastnaesites associated with allanite (Aln), muscovite (Musc) and ilmenite (IIm) in the leucomonzogranite (sample ME10A); e) and f) oxyfluorides (REE-Oxf) associted with altered zircon in the leucomonzogranite. Light areas: Ce-rich; dark areas: La-rich (sample 05-I-164); g) and h): Monazite grains (Mnz) in the biotite granite; i): BSE image of a monazite grain with reaction rim of $\mathrm{Fe}$-oxide (Ox-Fe); j), k) and I): allanite associated with epidote (ep) and ilmenite (ilm). .27

Figure 11. Optical and backscattered electron images (BSE) of REE bearing minerals in the SMGM, a), b) and c): thorite - zircon- xenotime association in the biotite granite (sample AZME-7D) and in the leucomonzogranite; d), e), f) REE-bearing zircon associted with thorite (Th), bastnaesite (bast) and fluorite (FI) in the leucomonzogranite (samples AZME $4 \mathrm{~A}$ and $\mathrm{ME}-8 \mathrm{C}$ ); $\mathrm{g}$ ) zircon of the biotite granite (sample AZME-12B); h) and i) apatite grain in the biotite granite with Fe-oxide inclusions (white dots in h)); j), k) and I) Unidentified $\mathrm{Nb}$ Si-Y- REE mineral in association with titanite (Ttn) agglomerates. .28

Figure 12. a) to h): Mineral chemistry plots and respective chondrite normalized REE patterns with normalization values from Sun \& McDonough (1989) for REE-bearing minerals in the SMGM; i) Diagram of Linthout, (2007) showing the compositional variation of the SMGM monazites in the system 2REEPO4 - CaTh(PO4)2 - 2ThSiO4. 30

Figure 13. Mineral chemistry plots and respective chondrite normalized REE patterns with normalization values from Sun \& McDonough (1989) for REE-bearing minerals in the SMGM. a) to c): allanite; d) to f): thorite (Th) - xenotime (REE + Y) - zircon (Zr) solid solutions;g) to i): zircon;i) j) REE patterns for the PB1c zircons. 
Figure 14. Mineral chemistry plots and respective chondrite normalized REE patterns with normalization values from Sun \& McDonough (1989) for REE-bearing minerals in the SMGM. a) and b): apatite; c) to e): unidentified Nb-Si-Y-REE rich mineral. .32

Figure 15. a) to $c)$ Diagrams of $\mathrm{REE}+\mathrm{Y}$ contents, $\mathrm{Zr}$ contents, and $\mathrm{LaN} / \mathrm{YbN}$ ratios vs. $\mathrm{SiO} 2$ contents showing an increasing in the REE, mainly in the HREE, contents with the increasing in SiO2); d) to f) chondrite-normalized REE patterns of the granites, saprolites and alluvial sediments; normalization values from Sun \&McDonough (1989); g) REE patterns of the leucomonzogranite and associated saprolite normalized to the less evolved biotite granite (sample AZME07D), highlighting the enrichment in the HREE by a factor up to 5 .39

Figure 16. Map of geochemical anomalies for REE $+Y(p p m)$ in the SMGM. .40

\section{LISTA DE TABELAS}

Table 1. Relative amounts of REE minerals in the SMGM granites and in the alluvial sediments (- no observed, +low ++ medium, +++ high, SS: solid solution) and the respective REE contents (wt. \%) obtained by EPMA.

Table 2. Whole-rock compositions for granites, saprolites and alluvial sediments from the SMGM 


\section{RESUMO}

O Maciço Granítico Serra do Mendes (MGSM) está localizado na Província Estanífera de Goiás (PEG), que é caracterizada por corpos de granito de tipo A com conteúdos de estanho e elementos das terras raras associados. O maciço da Serra do Mendes é o maior corpo granítico da subprovincia do Paranã e possui 3 fácies principais pertencentes à Suíte Granítica Pedra Branca. Esta suíte tem idades de 1.77 a $1.74 \mathrm{Ga}$, com uma tendência subalcalina para alcalina e altas concentrações de Zr, Y e ETR.

Amostras de rocha fresca, saprolito e sedimentos de drenagem foram coletadas das fácies graníticas mais abundantes, PB1a e PB1c, com o objetivo de caracterizar os minerais portadores de ETR e suas concentrações. As técnicas analíticas incluíram petrografia, microscopia eletrônica de varredura, análise de química mineral por microssonda eletrônica (EPMA) e geoquímica de rocha total.

A fácies mais evoluída, PB1c, contém as concentrações mais elevadas de minerais portadores de ETR, sendo os mais notáveis fluocerita-Ce, oxifluoretos de ETR, bastnaesita, monazita, allanita, soluções sólidas de torita-zircão e torita-xenotima, além de apatita.

De acordo com a litogeoquímica, a fácies mais abundante, PB1a, contém concentrações de ETR de 363.8 a 985.9 ppm, e seu saprolito contém concentrações de 60 a 1283.9 ppm, com razões $L_{\mathrm{N}} / \mathrm{Yb}_{\mathrm{N}}$ entre 4 e 17,7. A facies PB1c contém ETR em concentrações entre 460.9 e 958.6 ppm, e seus saprolitos contêm concentrações de ETR de 495.7 e 902.1 ppm. As razões $\mathrm{LaN}_{\mathrm{N}}$ / $\mathrm{Yb}$ nas rochas e saprolitos estão entre 2 e 12.3. Ao lado dos minerais de terras raras, merece destaque a ocorrência de zircão e torita com até $20 \%$ de $\mathrm{ETR}_{2} \mathrm{O}_{3}+\mathrm{Y}_{2} \mathrm{O}_{3}$.

As concentrações de ETR, juntamente com fatores como o clima e morfologia da área de estudo, tornam o Maciço Granítico da Serra do Mendes um alvo interessante para prospecção e exploração de ETR.

PALAVRAS ChAVE: Minerais portadores de ETR, Maciço Granítico Serra do Mendes, intemperização 


\section{ABSTRACT}

The Serra do Mendes granite massif (SMGM) is located in the Goiás tin province (GTP), which is characterized by A-type granite bodies that bear tin and associated rare earth elements (REEs). The Serra do Mendes massif is the largest granitic body in the Paranã subprovince and has 3 main facies belonging to the Pedra Branca Granite Suite. This suite has ages of 1.77 to $1.74 \mathrm{Ga}$, a subalkaline to alkaline tendency and high concentrations of $\mathrm{Zr}$, $\mathrm{Y}$ and REEs.

Samples of fresh rock, saprolite and alluvial sediments were collected from the most abundant facies, PB1a and PB1c, with the objective of characterizing the REE-bearing minerals and their concentrations. The analytical techniques included petrography, scanning electron microscopy, mineral chemistry analysis with an electron probe micro-analyzer (EPMA) and total rock geochemistry.

The most evolved facies, PB1c, contains the highest concentrations of REE-bearing minerals, the most noteworthy of which are fluocerite-Ce, REE oxyfluorides, bastnaesite, monazite, allanite, solid solutions of thorite, zircon, fluorite and apatite.

REE contents in the most abundant facies, PB1a, range from 363.8 to $985.9 \mathrm{ppm}$, and its saprolite contains concentrations of 60 and 1283.9 ppm with $\mathrm{LaN} / \mathrm{YbN}$ ratios between 4 and 17.7. Facies PB1c contains REEs at concentrations between 460.9 and 958.6 ppm, and its saprolites contain concentrations of REEs of 495.7 and $902.1 \mathrm{ppm}$. The LaN/YbN ratios in the rocks and are between 2 and 12.3. Along with the REE minerals, it is noteworthy the occurrence of zircon and thorite with up to $20 \% \mathrm{REE}_{2} \mathrm{O}_{3}+\mathrm{Y}_{2} \mathrm{O}_{3}$.

These values together with factors such as the climate and morphology of the study area make the Serra do Mendes granite massif an interesting objective for prospecting and exploration for REEs.

KEY WORDS: REE bearing minerals, Serra do Mendes Granite Massif, weathering 


\section{INTRODUÇÃO E JUSTIFICATIVA}

A procura por jazidas de elementos terras raras (ETR) tem se tornado cada vez maior nos últimos anos, em razão da sua utilização na indústria de alta tecnologia e do monopólio da China na produção destes elementos (97\% de toda a produção mundial). Em 2010, o governo chinês anunciou que, em poucos anos, toda sua produção de terras raras seria destinada para seu mercado interno. Estes metais são utilizados em células fotovoltáicas, carros híbridos, turbinas eólicas, imãs de alto rendimento, supercondutores, luminóforos, catalisadores, entre outros.

Os fatores mencionados acima enquadram os ETR no grupo dos "Minerais Estratégicos", definição utilizada para um mineral escasso, além de essencial e/ou crítico para um país. De acordo com o Plano Nacional de Mineração 2030, existem três situações que permitem a caracterização de um bem mineral como estratégico:

- Elementos e minerais de que o país depende e que importa em grande escala, tais como o potássio, nitrogênio, fósforo e o carvão metalúrgico, essenciais para setores vitais da nossa economia.

- Minerais portadores de ETR, lítio, tântalo, entre outros, cuja demanda é crescente e que deverá se expandir ainda mais nas próximas décadas devido a sua aplicação em produtos de alta tecnologia, denominados minerais "portadores do futuro"

- Minerais em que o Brasil apresenta vantagens comparativas naturais e liderança internacional em reservas e produção, tais como os minérios de ferro e nióbio.

A partir de todos os motivos listados, entende-se que é muito importante um melhor conhecimento técnico/geológico sobre estes elementos, fator imprescindível para o país se tornar cada vez menos dependente do mercado externo, por meio da exploração de suas próprias reservas. No Brasil, importantes alvos para pesquisa de terras raras estão relacionados a granitos do tipo $A$, tema que está sendo investigado dentro de um grande projeto apoiado pelo CNPq-CT MINERAL (Bastos Neto \& Botelho, 2013). O projeto aborda granitos da região de Pitinga, no Amazonas, e granitos da Província Estanífera de Goiás, na qual está inserida esta Dissertação de Mestrado, cuja proposta é a "Caracterização Mineralógica, Geoquímica e Potencial Econômico de Ocorrências de Terras Raras do Maciço Granítico Serra do Mendes, Goiás".

Trabalhos anteriores (Marini et al, 1992; Teixeira e Botelho, 1999; Teixeira, 2002, Santana, 2013 e Santana et al 2015) descrevem o potencial para terras raras em determinados granitos encontrados na região. O primeiro aborda a Província Estanífera de Goiás como um todo e os demais trabalhos abordam as subprovíncias Tocantins ou Paranã. São abordadas as concentrações de TR em rocha fresca, saprolitizada e alterada por processos hidrotermais. 
Diversos corpos graníticos apresentam potencial econômico, em especial os maciços Pedra Branca e Serra Dourada. O Maciço Serra do Mendes ainda é pouco conhecido, mas anomalias de ETR foram evidenciadas por Marini et al. (1992).

\section{OBJETIVOS}

Com o presente trabalho pretende-se caracterizar as ocorrências de ETR no maciço granítico Serra do Mendes e os minerais magmáticos e hidrotermais portadores desses elementos. Além disto, serão investigadas possíveis concentrações desses minerais em aluviões, no interior e na borda do maciço granítico, além de possíveis enriquecimentos supergênicos de TR, como aqueles descritos por Santana (2013) e Santana et al (2015) no Maciço Serra Dourada.

Depósitos de TR de enriquecimento supergênico estão entre os mais importantes descritos na literatura. $O$ depósito deste tipo mais conhecido e importante é o de adsorção iônica, descrito em diversos trabalhos (Bao e Zao 2008, Sanematsu et al 2009 e Sanematsu et al 2013) e normalmente associado a granitos. Este tipo de depósito consiste na adsorção de ETR em argilominerais presentes no solo (principalmente caolinita) através da alteração dos minerais detentores de ETR, com a interação de água meteórica. Os trabalhos citados anteriormente, além de Bau (1999), descrevem este processo.

A pesquisa terá como objetivo final uma avaliação da importância econômica dessas ocorrências.

\section{ESCOPO DA DISSERTAÇÃO}

A presente dissertação de mestrado se divide em duas partes: a primeira é introdutória, informado os objetivos, generalidades da área de estudo e a geologia regional. A segunda parte, contém o resultado da dissertação de mestrado, feita em forma de artigo científico, intitulado "Mineralogic and geochemical characterization of rare-earth occurrences in the Serra do Mendes Massif, Goiás, Brazil" a ser submetido à revista especializada Journal of Geochemical Exploration.

\section{LOCALIZAÇÃO E ASPECTOS FISIOGRÁFICOS}

A zona de estudo está localizada na região do Nordeste Goiano, nas imediações da municipalidade de Monte Alegre de Goiás aproximadamente a $15 \mathrm{~km}$ da área urbana. Partindo de Brasília, o acesso pode ser feito pela via BR-020 em direção a Planaltina, em seguida tomase a rodovia estadual GO-118, passando pelas cidades de São Gabriel de Goiás, São João D' 
Aliança, Alto Paraiso de Goiás, Teresina de Goiás até a cidade de Monte Alegre de Goiás. A figura 1 mostra a localização da área estudada com seus principais acessos.

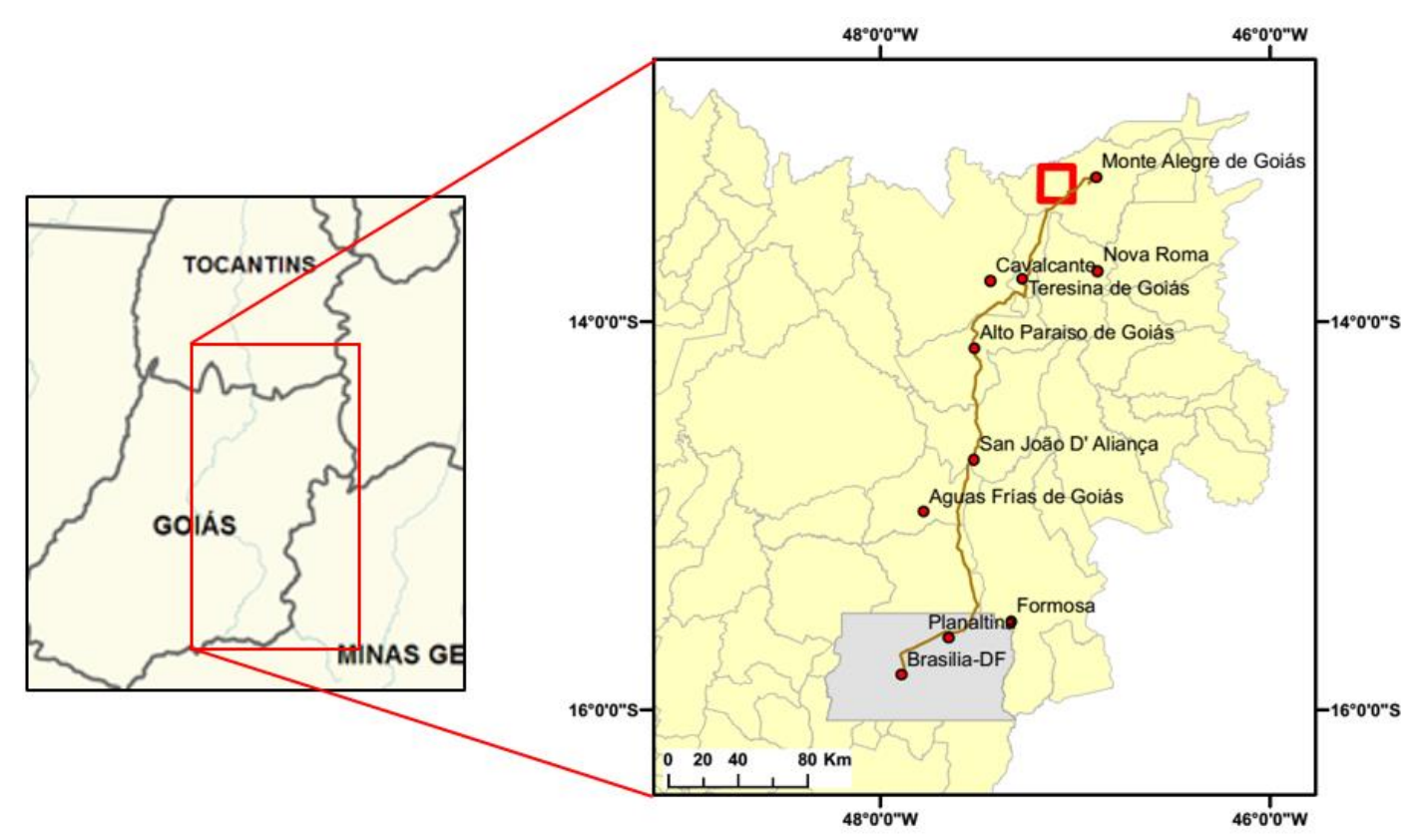

Figura 1. Localização da área estudada e principais acessos.

\subsection{Geomorfologia}

O relevo de uma área bem como seus tipos de solo e clima constituem aspectos fundamentais para a evolução dos depósitos de ETR por adsorção em argilo-minerais, que são favorecidos por superfícies de aplainamento, localizadas sobre rochas graníticas com algum enriquecimento prévio de ETR.

A área de estudo caracteriza-se por apresentar superfícies relativamente aplainadas interrompidas por altos topográficos de formas circulares, pertencentes aos corpos graníticos intrusivos e suas rochas encaixantes imediatas (Figura 2), além de colinas e, em menor proporção, estruturas hog-backs. Segundo Latrubesse e Carvalho (2006), de maneira geral a região está subdividia em três unidades geomorfológicas:

a) Superfície Regional de Aplainamento (SRA), que abrange áreas de depressões, formadas pela bacia hidrográfica do Rio Paranã, com sistema de drenagens no sentido sul. A região é constituída predominantemente por as rochas da Suíte Aurumina, principal encaixante do Granito Serra do Mendes. "Uma SRA é uma unidade denudacional gerada pelo arrasamento de uma superfície de terreno dentro de um determinado intervalo de cotas e este aplainamento se dá de forma relativamente independente dos controles geológicos regionais 
(litologias e estruturas). Uma SRA, na sua distribuição espacial, pode seccionar/aplainar sobre limites litológicos e estilos estruturais, erodindo diversas unidades geológicas" (Latrubesse e Carvalho, 2006)

b) Zonas de Erosão Recuante, que são zonas onde as Superfícies Regionais de Aplainamento encontram-se escalonadas em diferentes cotas, geralmente delimitadas por escarpas de erosão. Grandes reentrâncias marcam a erosão das superfícies de aplainamento antigas a partir de um nível de base inferior (local o regional), associado à rede de drenagem que evolui por erosão recuante, dissecando as superfícies de aplainamento e gerando outras SRAs. Estas zonas (ZER) frequentemente passam transicionalmente para SRA, que atua como nível de base local. Em algumas zonas onde o contato entre superfícies é muito abrupto, embora exista uma Zona de Erosão Recuante, ela não foi cartografada em função da escala, sendo simplesmente indicado o contato entre as superfícies.

c) Morros e Colinas (MC), caracterizada na região pelos granitos Serra do Mendes e Mangabeira e pela Serra de Bom Jardím, composta de rochas metassedimentares e metavulcânicas da Formação Arraias. $\mathrm{Na}$ área de estudo, as intruções graníticas respondem por relevos dômicos de formas circulares e ovais. Trata-se de corpos exumados associados à evolução da superfície Regional de Aplainamento. Geomorfologicamente podem ser classificados como inselbergs. Estas formas são o resultado da erosão diferencial e, por resistirem mais à erosão/denudação, sobressaem ao relevo circundante (figura. 2).

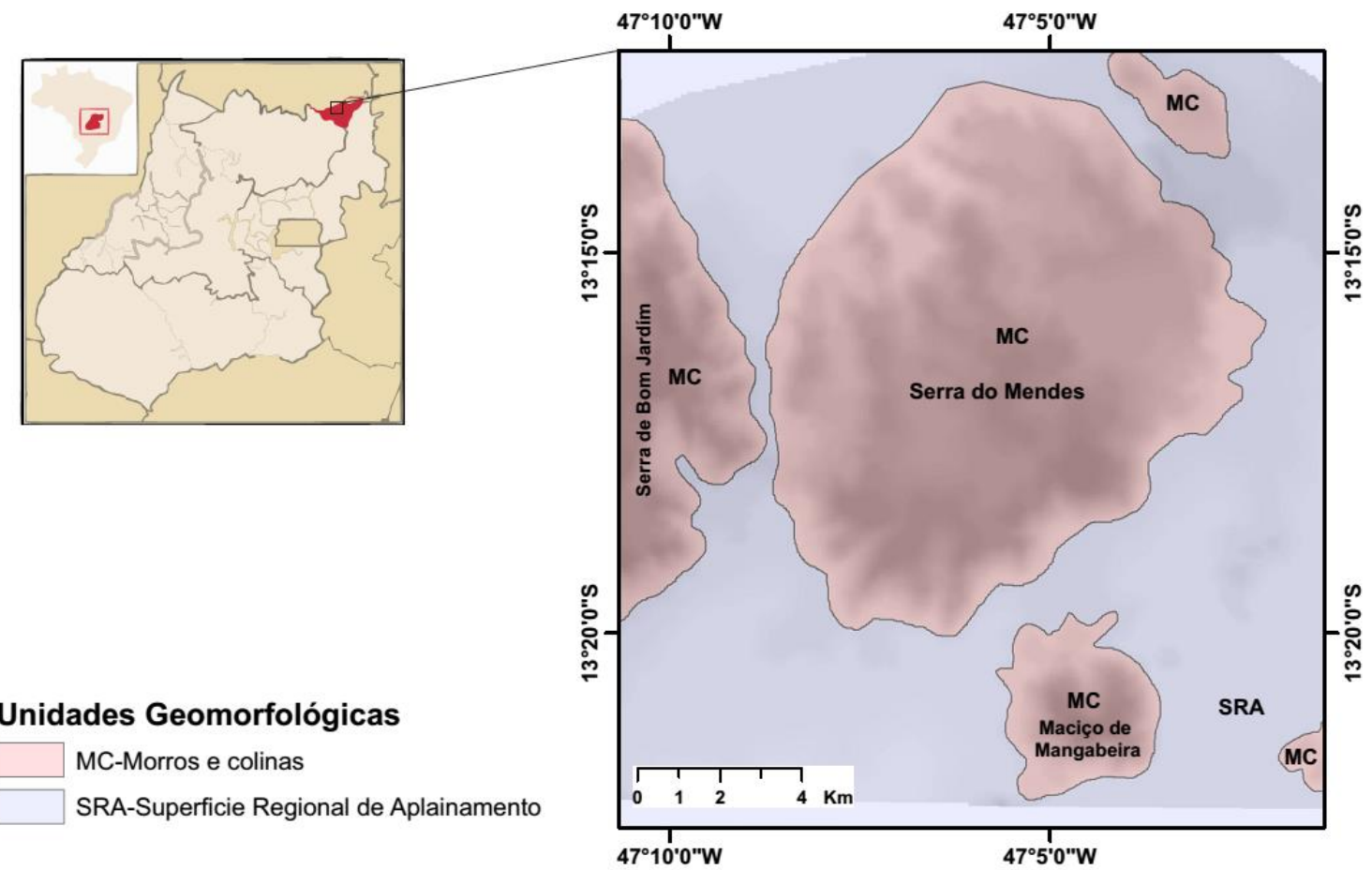

Figura 2. Mapa geomorfológico da área estudada. Fonte: Sistema Estadual de Estatística e Informações Geográficas do Estado de Goiás-Superintendência de Geologia e Mineração. 


\subsection{Solos}

Os solos da região do Norte Goiano podem ser classificados em três tipos diferentes de acordo com o Manual Técnico de Pedología, publicado pelo IBGE em 2007.

Argissolos: Os solos desta classe têm como característica marcante um aumento de argila do horizonte superficial A para o subsuperficial B que é do tipo textural (Bt), geralmente acompanhado de boa diferenciação também de cores e outras características. As cores do horizonte $\mathrm{Bt}$ variam de acinzentadas a avermelhadas e as do horizonte $\mathrm{A}$, são sempre mais escurecidas. A profundidade dos solos é variável, mas em geral são pouco profundos. São juntamente com os Latossolos, os solos mais expressivos do Brasil, sendo verificados em praticamente todas as regiões.

Latossolos: Em geral são solos muito intemperizados, profundos e de boa drenagem. Caracterizam-se por grande homogeneidade de características ao longo do perfil, mineralogia da fração argila predominantemente caulinítica ou caulinítica-oxídica e praticamente ausência de minerais primários de fácil intemperização.

Neossolos litólicos: São marcadamente rasos e pouco desenvolvidos, com ausência de horizonte $\mathrm{B}$ distinguível e presença de material mineral/regolítico imediatamente abaixo do horizonte orgânico. Embora bem distribuídos pelo Brasil, os neossolos litólicos não apresentam expressivo volume, sendo encontrados principalmente em regiões de morrarias e serras.

\subsection{Clima e vegetação.}

O clima local é predominantementeTropical quente com duas estações bem definidas: verões quentes e chuvosos entre os meses de outubro a abril e invernos quentes e secos entre os meses de maio a setembro.

A vegetação é de tipo cerrado ou savana, desenvolvida em terrenos areníticos, lixiviados e fortemente aluminizados. O cerrado está composto de formações geralmente cobertas ou entremeadas por plantas lenhosas. O cerrado ou savana corresponde a uma vegetação xeromorfa, de clima estacional (onde aproximadamente seis meses são marcados pela seca). Ocorre com frequência vegetação arbustiva como Vellozias Squamata (Canela de Ema).

\section{MATERIAIS E MÉTODOS}

A área de estudo foi mapeada e amostrada em trabalhos de conclusão do Curso de Geologia da UnB (Miranda e Ribas, 2006; Castanheira e Andrade, 2006), sendo que algumas 
amostras foram aproveitadas nessa Dissertação de Mestrado. Foi realizado mais um trabalho de campo com o objetivo de reconhecimento geológico, amostragem de rochas, de saprolitos e concentração de minerais pesados em drenagems. Para auxiliar na identificação dos locais com maiores concentrações dos minerais de interesse, foi utilizado um gamaespectrômetro, já que minerais de ETR comumente incorporam $\mathrm{U}$ e Th em suas estruturas cristalinas.

A partir das amostras de rocha coletadas, foram confeccionadas seções delgadas e uma seção de cada amostra foi moída em panela de ágata e enviada para análise de rocha total. Os sedimentos de córrego foram secados em estufa a $50^{\circ} \mathrm{C}$ e posteriormente peneirados e separados para observação em maior detalhe em microscópio de luz transmitida e lupa binocular. Deste concentrado, alguns minerais foram recuperados com pinças e montados em suportes com resina de epóxi, polidos em disco rotativo com pasta diamantada e revestidos com película de carbono para serem examinados na microssonda eletrônica.

Análises de rocha total e elementos traço foram feitas no Laboratório ACME, Canadá, onde elementos maiores, menores e traços foram detectados por ICP-ES e ICP-MS, após fusão com metaborato de lítio, diluição e digestão em ácido múltiplo de $0,2 \mathrm{~g}$ de amostra, com exceção dos metais base, que foram extraídos por água-régia. A perda ao fogo, ou Loss on Ignition (LOI), é dada pela diferença de peso após incineração a $1000^{\circ} \mathrm{C}$. Foram ainda analisados carbono e enxofre totais em forno Leco.

As análises em microssonda eletrônica foram realizadas na Universidade de Brasília, no Laboratório de Microssonda Eletrônica, utilizando-se uma JEOL JXA-8230 equipada com cinco espectrômetros WDS para análises quantitativas e um EDS para análises qualitativas. Primeiramente realizaram-se as análises SEM-EDS para identificar os minerais ricos em $Y$ e ETR e, em seguida, foram feitas as análises quantitativas. Nestas análises dividiu-se os elementos em dois programas: um contendo os elementos $\mathrm{F}, \mathrm{Al}, \mathrm{Si}, \mathrm{P}, \mathrm{Nb}, \mathrm{Mn}, \mathrm{Ti}, \mathrm{Y}, \mathrm{Ta}, \mathrm{Ca}$, Fe e Zr e o outro Na, Ho, Er, Tm, Yb, Lu, Pb, K, Sm, Eu, Gd, Tb, Dy, Th, Sr, La, Ce, Pr, Nd, U e $\mathrm{Ba}$. As condições de análise foram: $15 \mathrm{kV}$ de aceleração de voltagem, $10 \mathrm{nA}$ de corrente e 1 $\mu \mathrm{m}$ de diâmetro dos feixes de elétrons para o primeiro programa e $20 \mathrm{kV}$ de aceleração de voltagem, $50 \mathrm{nA}$ de corrente e $1 \mu \mathrm{m}$ de diâmetro dos feixes de elétrons para o segundo programa. Os tempos de contagem para todos os elementos foi de 10 segundos no pico e 5 segundos no background. Para os elementos $\mathrm{F}, \mathrm{Al}, \mathrm{Si}, \mathrm{P}, \mathrm{Mn}, \mathrm{Ti}, \mathrm{Fe}, \mathrm{Na}$ e K utilizou-se a linha Ka, para Y, Er, Tm, Yb, Lu, Eu, Gd, Tb, Sr, La, Ce, Nd e Ba a linha La, para Ca a linha K $\beta$ e para $\mathrm{Nb}, \mathrm{Zr}$, Ho, Sm, Dy e $\operatorname{Pr}$ a linha $\mathrm{L} \beta$. Vidros silicáticos de Ca-Al sintéticos contendo cada ETR foram usados como padrões de ETR, com excessão do $\mathrm{Ce}$, que foi analisado com um padrão de $\mathrm{CeO}_{2}$ sintético. Os outros padrões utilizados para calibração foram: topázio $(\mathrm{F})$, microclínio (Al, K e Si), apatita ( $\mathrm{P}$ e Ca), $\mathrm{LiNbO}_{3}(\mathrm{Nb}), \mathrm{MnTiO}_{3}\left(\mathrm{Mn}\right.$ e Ti), $\mathrm{YFe}_{2} \mathrm{O}_{12}(\mathrm{Y}), \mathrm{LiTaO}_{3}$ $(\mathrm{Ta})$, andradita $(\mathrm{FeO})$, baddeleita $(\mathrm{Zr})$, albita $(\mathrm{Na})$, vanadinita $(\mathrm{Pb}), \mathrm{ThO}_{2}(\mathrm{Th}), \mathrm{SrSO}_{4}(\mathrm{Sr}), \mathrm{UO}_{2}$ 
(U) $\mathrm{e} \mathrm{BaSO}_{4}(\mathrm{Ba})$. Correções de interferência foram executadas em todos os casos necessários.

\section{CONTEXTO GEOLÓGICO DA ÁREA DE PESQUISA}

O maciço Serra do Mendes insere-se dentro da Província Estanífera de Goiás (PEG), composta por quatro subprovíncias, onde foram encontrados maciços granitoides portadores de estanho com ETR associados (Marini e Botelho, 1986; Marini et al. 1992). A província é constituída por cerca de vinte corpos graníticos e filões pegmatíticos de idade Paleoproterozóica a Neoproterozóica, intruidos em rochas metassedimentares da Formação Ticunzal e granitos da Suíte Aurumina e superpostos por rochas sedimentares dos grupos Serra da Mesa, Araí e Paranoá.

As duas principais subprovíncias estaníferas da PEG estão situadas na porção norte, abrangendo também o extremo sul do estado do Tocantins. Na figura 3, a oeste, está localizada a Subprovíncia Tocantins (SPT), que tem o Maciço Serra Dourada como principal alvo para depósitos de terras raras. O Maciço Serra do Mendes está inserido na Subprovíncia Paranã (SPP), localizada a leste na mesma figura.

A subprovíncia Paranã é constituída pelos granitos Pedra Branca, Mocambo, Magabeira, Mendes e Sucuri, todos do tipo A. Este magmatismo granítico é denominado de Suíte Pedra Branca (PB), constituída pelos granitos, PB1 e PB2, com idades entre 1,77 e 1,74 Ga. No Maciço Serra do Mendes, encontra-se apenas a fase Pb1, dominantemente Pb1a, que apresenta tendência alcalina a subalcalina, alto conteúdo de Zr, Y e ETR.

Trabalhos mais recentes (Botelho et al. 2006; Alvarenga et al. 2007) incluem nesta subprovíncia os granitos peraluminosos da Suíte Aurumina (2,15 Ga.), que hospedam depósitos de estanho, tântalo, urânio e ouro, mas que não têm potencial para depósitos de terras raras. Os granitos do tipo A são intrusivos em rochas da Suíte Aurumina e/ou da Formação Ticunzal, localizados na porção externa da Faixa Brasília (Alvarenga et al, 2007). Os mesmos autores descrevem que estes corpos constituem altos topográficos circulares ou elípticos que se destacam do relevo mais suave das rochas encaixantes. 


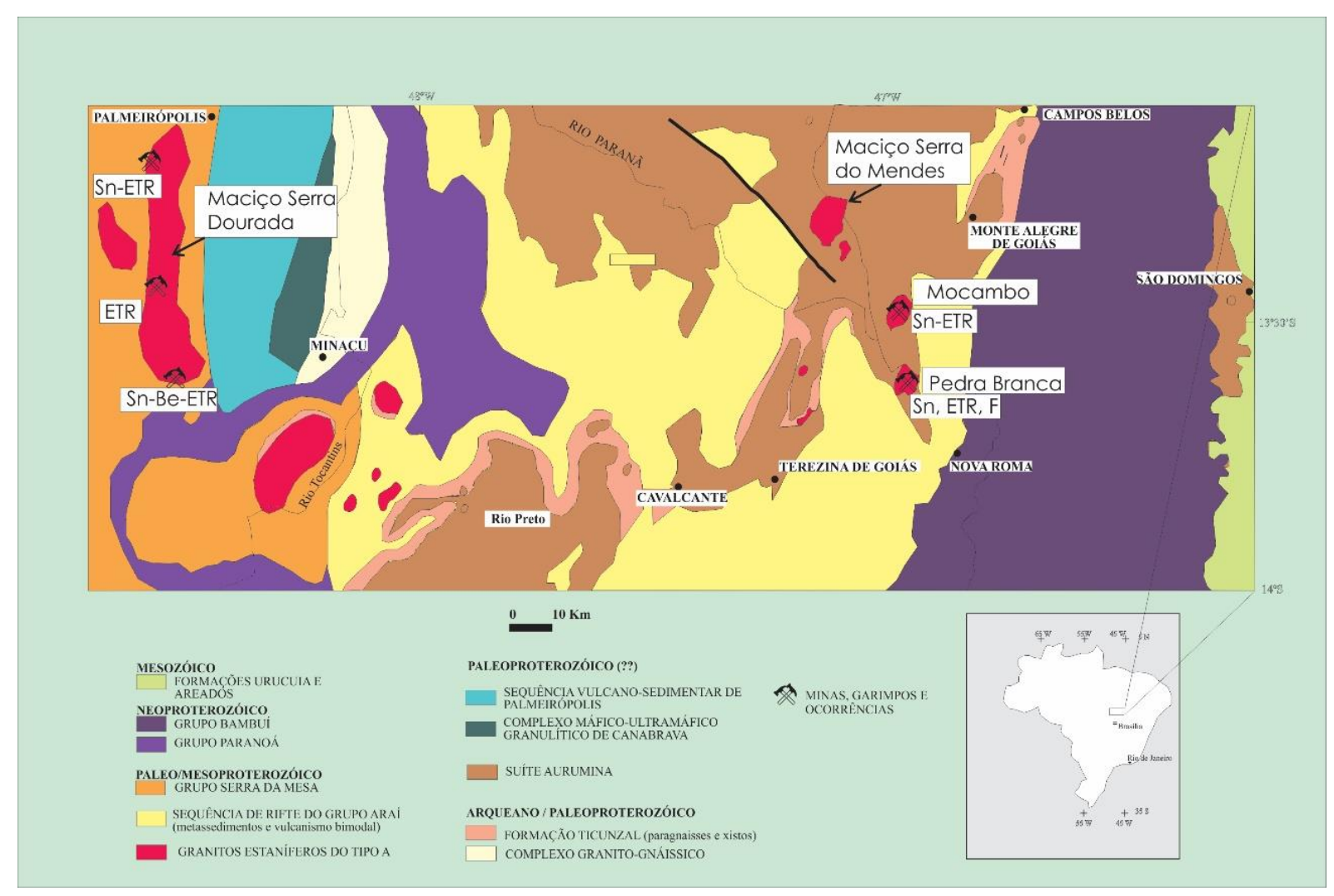

Figura 3. Mapa com os principais maciços graníticos com potencial para ETR na PEG, com localização do Maciço Serra do Mendes (Botelho, 2013).

De acordo com Marini e Botelho (1986) e Marini et al. (1992), estas rochas graníticas constituem corpos circulares, predominantemente porfiríticos e com orientação mineral difusa, nos quais destacam-se megacristais de K-feldspato e cristais de quartzo azulado. É importante ressaltar que a biotita é o único mineral máfico presente. Também são observados granitos greisenizados e greisens mineralizados com cassiterita nos maciços Serra do Mendes, Mangabeira, Mocambo, Pedra Branca e Sucuri. Estes são resultados de fenômenos tardi a pós-magmáticos, representados por greisenização, albitização e microclinização.

\subsection{Maciço Serra Do Mendes}

O maciço Serra do Mendes, constitui um corpo de forma elipsoide, com o eixo maior NE com cerca de $15 \mathrm{~km}$ e com o eixo menor em torno de $10 \mathrm{~km}$ constituindo o maior corpo granítico da Subprovincia Estanífera de Paranã e é pouco conhecido, já que não constitui alvo importante para prospecção de estanho (figuras 3 e 4). Estudos de maior detalhe são decorrentes de levantamentos geológicos realizados durante trabalhos de formatura de alunos de Graduação em Geologia da Universidade de Brasília (Miranda e Ribas, 2006; Castanheira e Andrade, 2006). É constituído predominantemente por biotita monzogranito, com deformação proeminente, principalmente nas bordas. Esta deformação oblitera as texturas magmáticas, 
mas em regiões menos deformadas têm sido observadas texturas gráfica e micrográfica/granofírica, além de grãos de quartzo euédricos a subédricos, semelhantes a feições encontradas em granitos rapakivi.

Em sua porção central, o maciço serra do Mendes possui um corpo de leucogranito mais evoluído, denominado de Fazenda Poção, onde estão concentradas as poucas ocorrências de estanho (figura 4). São descritas ainda ocorrências de sienogranito rico em fluorita. O leucogranito da Fazenda Poção é o principal alvo para terras raras, pois tem como minerais acessórios, allanita, monazita, torita, além de maior concentração de terras raras pesadas (ETRP) em relação ao biotita granito principal.

Dados petrográficos e geoquímicos permitem classificar a fácies predominante do Maciço Serra do Mendes como pertencente à Família PB1 de Suíte Pedra Branca, equivalente ao biotita monzogranito à fácies PB1a, o fluorita biotita sienogranito à PB1b e o leucogranito Poção e diques de biotita granito porfirítico à fácies $\mathrm{Pb} 1 \mathrm{c}$. O contato observado desta unidade com a Suíte Aurumina é tectônico, porém o caráter intrusivo da Suíte Pedra Branca em relação aos granitos peraluminosos é evidenciado por xenólitos decimétricos de biotita muscovita granito. O contato observado com a Formação Ticunzal é tectônico, marcado por uma faixa centimétrica de milonito fino (Miranda e Ribas, 2006). 

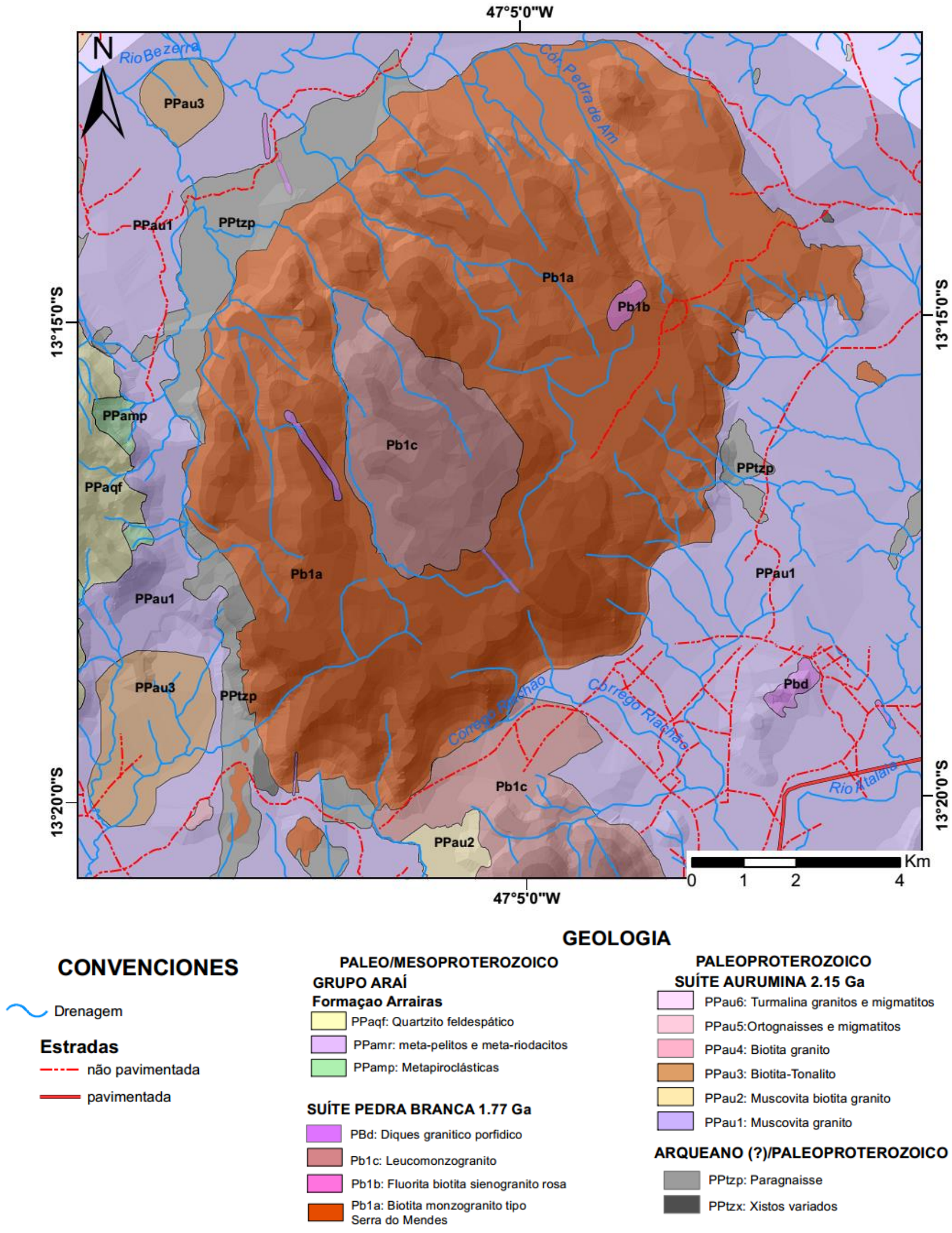

\section{GEOLOGIA}

\section{GRUPO ARAI}

\section{Formaçao Arrairas}

PPaqf: Quartzito feldespático

PPamr: meta-pelitos e meta-riodacitos

PPamp: Metapiroclásticas

SUITE PEDRA BRANCA 1.77 Ga

PBd: Diques granitico porfidico

Pb1a: Biotita monzogranito tipo

Serra do Mendes
PALEOPROTEROZOICO SUITE AURUMINA $2.15 \mathrm{Ga}$

PPau6: Turmalina granitos e migmatitos

PPau5:Ortognaisses e migmatitos

PPau4: Biotita granito

PPau3: Biotita-Tonalito

PPau2: Muscovita biotita granito

PPau1: Muscovita granito

\section{ARQUEANO (?)/PALEOPROTEROZOICO}

PPtzp: Paragnaisse

PPtzx: Xistos variados

Figura 4. Mapa geológico do Maciço Serra do Mendes e adjacências. Adaptado de Miranda \& Ribas (2006) e Castanheira \& Andrade (2006). 
6.1.1 Biotita monzogranito (Pb1a): A fácies biotita monzogranito $\mathrm{Pb} 1 \mathrm{a}$ é a mais abundante no Granito Serra do Mendes (figura 5). É composta por rochas de coloração escura, fortemente foliadas, faneríticas medias a grossas, inequigranulares, localmente porfiríticas constituídas de 26 a $28 \%$ de quartzo,23-21\% de microclínio, $18-21 \%$ de albita, $10-13 \%$ de biotita, 5-7\% de muscovita e 5-7\% de ilmenita, além de apatita, zircão, monazita, fluorita e allanita como acessórios. Os minerais com conteúdos consideráveis de ETR são monazita, torita, zircão, allanita e apatita. Destacam-se, em lâmina, os cristais subédricos de ilmenita com avançadas coroas de reação formadas por titanita, bem como a textura de intercrescimento gráfico. Estas rochas apresentam uma foliação milonítica que as distinguem das demais rochas do maciço.

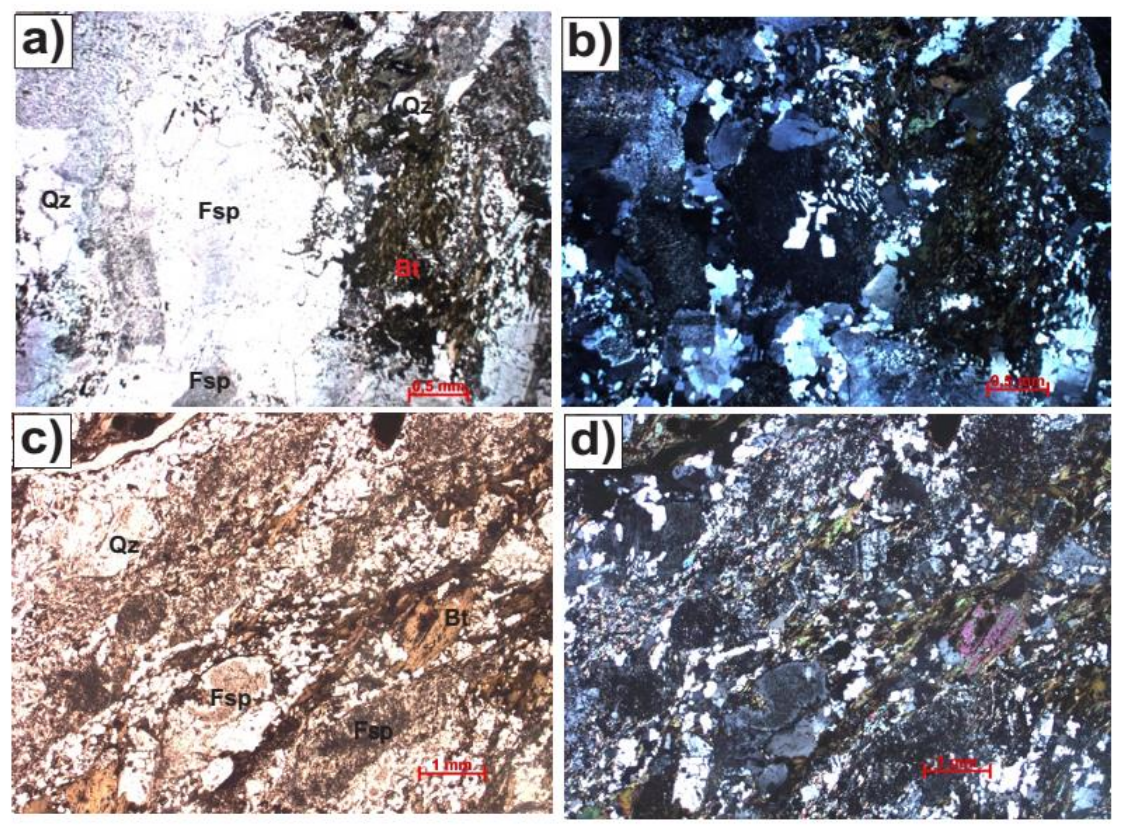

Figura 5. Fotomicrografias do biotita monzogranito. a(P//) e $b(P X)$ : amostra AZME-8B com textura granofírica preservada. $c(P / /)$ e d(PX): amostra AZME-01 com marcada foliação, onde se observa, quartzo e microclínio deformados.(Qz: quartzo; Fsp: microclínio; Bt: biotita)

6.1.2 Fluorita biotita sienogranito (Pb1b): A fácies fluorita biotita sienogranito foi individualizada como um pequeno corpo na porção centro-leste da Serra do Mendes. A textura fanerítica média a fina, a foliação incipiente e a presença de fluorita em amostras de mão, são critérios que a distingue das demais fácies da Suíte Pedra Branca. Sua composição mineralógica é $28-30 \%$ de quartzo, 23-28\% de microclínio, $8-10 \%$ de albita, $9-12 \%$ de biotita, $12-14 \%$ de muscovita e $8-12 \%$ de fluorita como minerais essenciais e apatita, opacos e epidoto como acessórios. Suas características ígneas estão muito bem preservadas, sendo comum a textura granofírica (figura 6). 


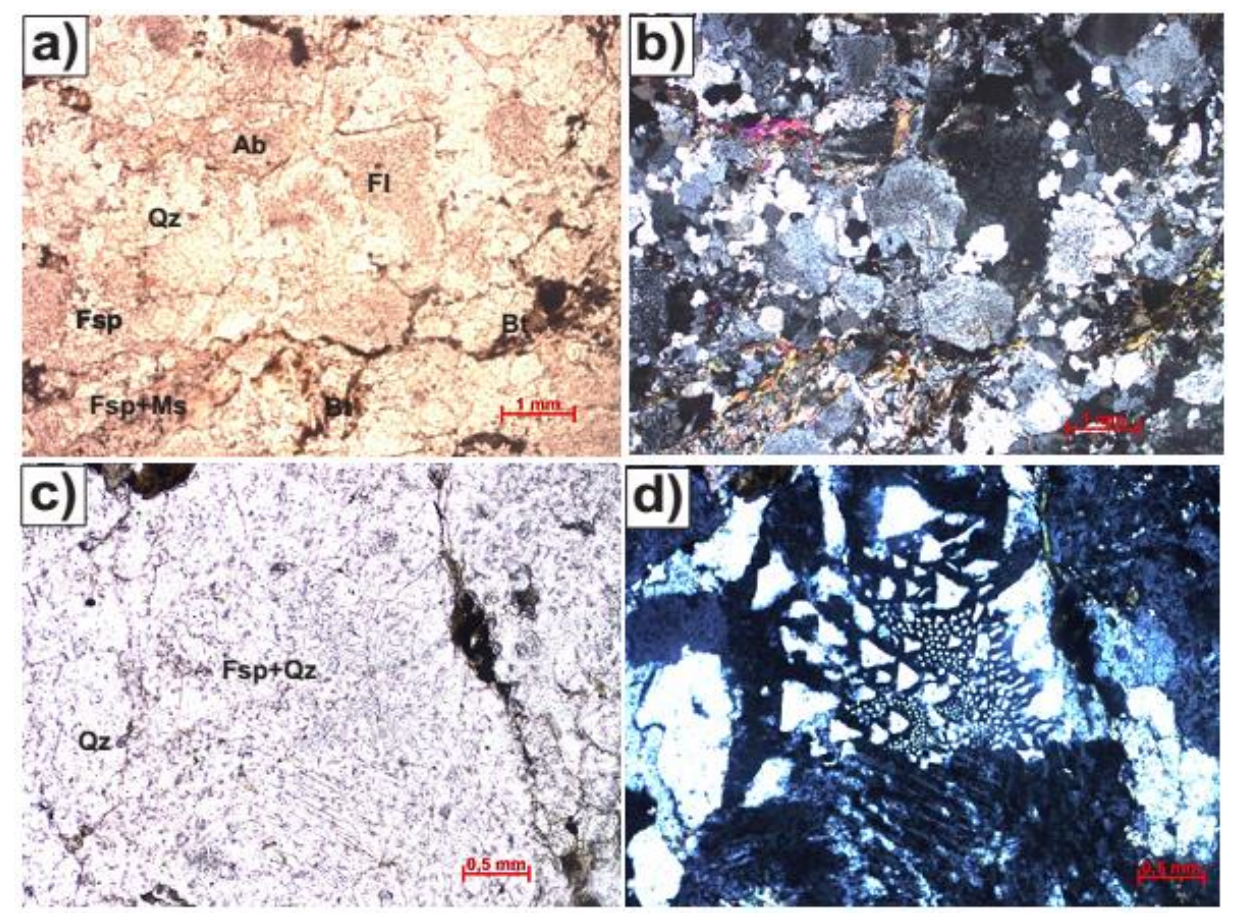

Figura 6. Fotomicrografias do fluorita biotita sienogranito (amostra TF171B), a(P//) e b(PX): textura e associação mineral típicas da rocha; $c(P / /)$ e d(PX): Textura granofírica preservada. (Qz: quartzo; Fsp: microclínio; Ab; albita; Fl: fluorita)

6.1.3 Leucomonzogranito (Pb1c): A fácies Pb1c é conhecida como o leucogranito Poção, por ter afloramentos na área da Fazenda Poção, e corresponde ao corpo mais evoluído que está localizado na parte central do Granito Serra do Mendes (figura 4). Ocorre também como diques a noroeste do maciço. É um muscovita leucomonzogranito, composto por 32-35\% de quartzo, $24-26 \%$ de microclínio, $18-20 \%$ de albita, $12-15 \%$ de muscovita e $4-6 \%$ de fluorita, além de epidoto, rutilo e titanita como acessórios e secundários (figura 7). Minerais portadores de ETR como bastnaesita, fluocerita e oxifluoretos de ETR são representativos desta fácies.

Os diques de biotita granito porfirítico afloram como matacões verticalizados in situ, com matriz escura, onde se destacam os fenocristais esbranquiçados de K-feldspato e quartzo azul. Têm composição monzogranítica e sua mineralogia essencial é 30\% de quartzo, $25 \%$ de Kfeldspato, $20 \%$ de plagioclásio, $15 \%$ de biotita, acompanhada de ilmenita, apatita, zircão, fluorita e titanita, como minerais acessórios, e calcita, muscovita, zoisita e epidoto como minerais secundários. 

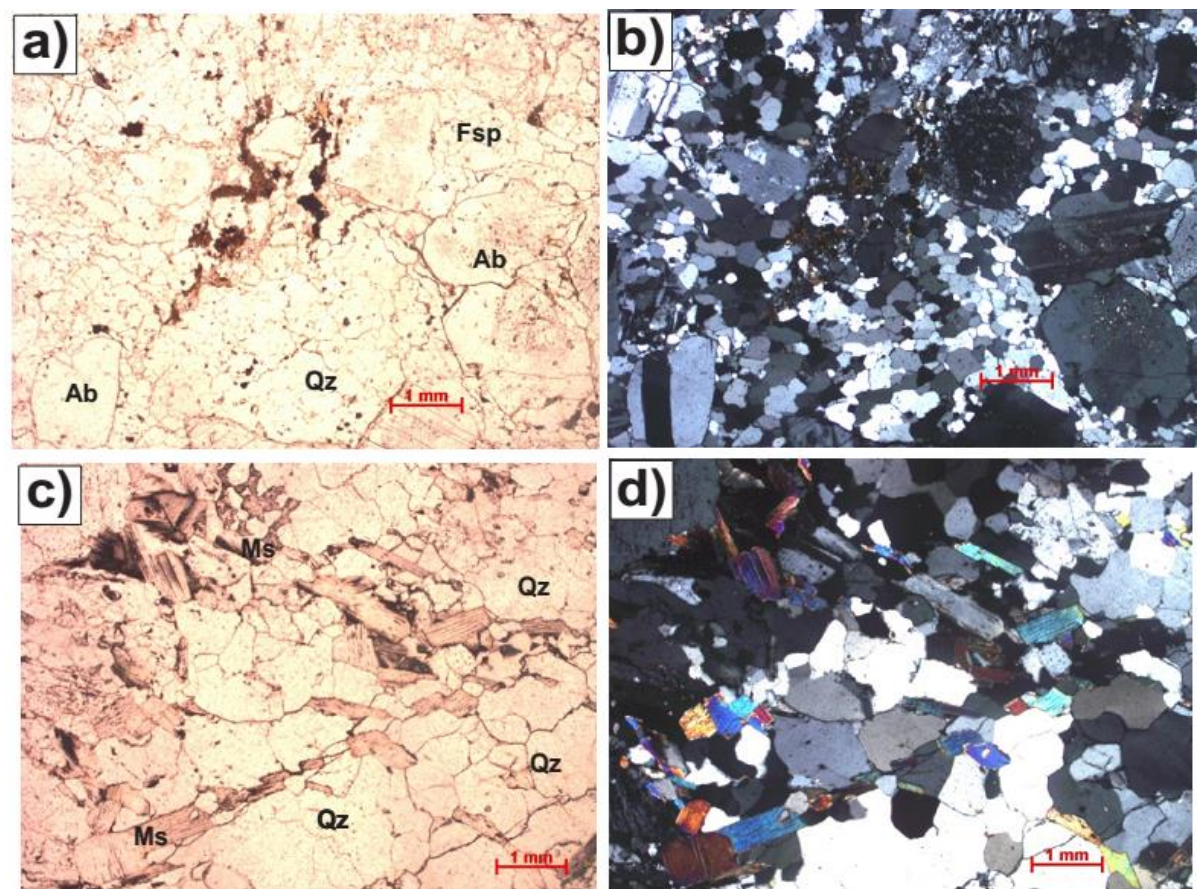

Figura 7. Características representativas do leucomonzogranito (fácies PB1c) no MGSM. a(P//) e b(PX): Amostra ME-10A com mineralogia típica. $c(P / /)$ e $d(P X)$ : Muscovita com orientação incipiente na amostra AZME-04D.

As composições modais para as diferentes fácies graníticas do MGSM foram plotadas no gráfico de Streckeisen (1974) para classificação de rochas ígneas plutônicas (figura 8), onde se evidenciam as composições monzograníticas para as fácies PB1a e PB1c e a composição sienogranítica para a fácies PB1b.

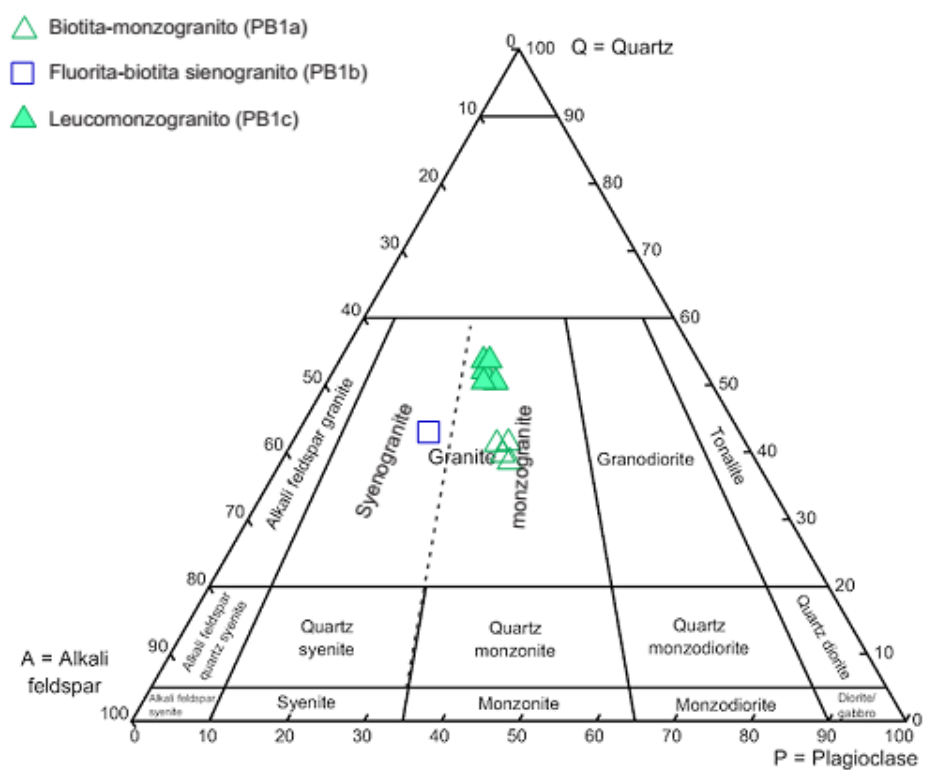

Figura 8. Gráfico de Streckeisen (1974) para classificação modal de rochas plutônicas, com amostras das diferentes fácies graníticas do MGSM. 


\section{FORMAS DE OCORRÊNCIA DE ETR NO MGSM}

Os ETR apresentam-se no MGSM em diferentes formas de ocorrência. Na forma mais comum, minerais concentradores de ETR, principalmente allanita, monazita, torita e zircão, encontram-se hospedados no leucomonzogranito (fácies PB1c) não alterado, ocorrendo como minerais acessórios, mas em concentrações já consideradas anômalas como assinalado por Marini et al. (1992). Ainda na rocha não alterada, ocorrem outros minerais de TR secundários (bastnaesita, fluocerita, oxifluoretos de ETR), como resultado de alteração hidrotermal e interação do granito com fluidos ricos em $\mathrm{Fe} \mathrm{CO}_{2}$. Outra forma de ocorrência observada foi em zonas onde o granito encontra-se saprolitizado, no qual monazita, torita e zircão se comportam como minerais resistatos permanecendo na rocha alterada entre minerais argilosos. A alteração contínua do granito por agentes intempéricos físicos e químicos resulta na total lixiviação dos minerais menos resistentes, com posterior concentração dos mais resistentes e densos na forma de depósitos de placer, o que constitui em mais uma forma de ocorrência observada. Finalmente, em estágios avançados da alteração do granito e concomitantes à pedogênese, observa-se a formação de camadas argilosas pertencentes a saprolitos que incorporam ETR. No artigo a ser submetido (ítem 9) descreve-se as características principais dos minerais portadores de ETR encontrados no maciço granítico Serra do Mendes, assim como as análises de rocha total de rochas e saprolitos das duas principais fácies graníticas estudadas.

\section{REFERÊNCIAS}

Alvarenga, C.J.S.; Dardenne, M.A.; Botelho, N.F.; Machado, M.A.; Lima, O.N.B.; Almeida, T. 2007. Relatório final das folhas Monte Alegre de Goiás, Cavalcante e Nova Roma. Programa Geologia do Brasil (PGB/CGB). UnB/CPRM.

Bao Z. \& Zhao Z. 2008. Geochemistry of mineralization with exchangeable REY in the weathering crusts of granitic rocks in South China. Ore Geology Reviews, 33:519-535.

Bastos Neto, A.C. e Botelho, N.F. 2013. Estudo integrado de geologia, mineralogia e caracterização tecnológica do minério no depósito associado ao granito Madeira e em planta piloto, com vistas à exploração de ETRP como coproduto do Sn-Nb-Ta na mina Pitinga (AM). Avaliação do potencial para ETRP de granitos análogos na Província Estanífera de Goiás. Chamada MCTI/CNPq/CT-Mineral № 76/2013: APOIO AO DESENVOLVIMENTO TECNOLÓGICO EM TERRAS RARAS. UFRGS/UnB, 45pp.

Bau M., 1999. Rare-earth element mobility during hydrothermal and metamorphic fluid-rock interaction and the significance of the oxidation state of europium. Chemical Geology 93 (3): 219-230. 
Botelho, N.F., Fuck, R.A., Dantas, E.L., Laux, J.H. \& Junges, S.L. 2006. The Paleoproterozoic peraluminous Aurumina granite suite, Goiás and Tocantins, Brazil: Geological, whole rock geochemistry and $\mathrm{U}-\mathrm{Pb}$ and $\mathrm{Sm}-\mathrm{Nd}$ isotopic constraints. In The Paleoproterozoic Record of the São Francisco Craton (F.F. Alkmin\& M. Noce, eds.). IGCP 509 annual meeting, Brazil.Field Guide \& Abstracts, 91.

Botelho, N.F. 2013. Potencial Econômico para Terras Raras em Granitos tipo-A da Província Estanífera de Goiás. XIII Simpósio de Geologia do Centro-Oeste, SBG, Cuiabá, Palestras.

Castanheira D. \& Andrade T.V. 2006. Projeto Nova Roma-Porto Real. Área II. Trabalho Final de Graduação, Universidade de Brasília.

Latrubesse, E. \& Carvalho, T. 2006. Geomorfologia do Estado de Goiás e Distrito Federal. Goiânia: Secretaria de Indústria e Comércio. 127 p.

Marini, O.J.; Botelho, N.F. 1986. A Província de Granitos Estaníferos de Goiás. Revista Brasileira de Geociências, 16:119 - 131.

Marini, O.J.; Botelho, N.F. e Rossi, P.H. 1992 Elementos terras raras em granitoides da província estanífera de Goiás. Revista Brasileira de Geociências, 22: 61 - 72.

Miranda F.S. Ribas, M.P.P 2006. Projeto Nova Roma-Porto Real. Área I. Trabalho Final de Graduação, Universidade de Brasília.

Sanematsu K., Murakami H., Watanabe Y., Duangsurigna S., Vilayhack S. 2009. Enrichment of rare earth elements (REE) in granitic rocks and their weathered crusts in central and southern Laos.Bulletin of the Geological Survey of Japan, 60:527-558.

Sanematsu K., Kon Y., Imai A., Watanabe K., Watanabe Y. 2013. Geochemical and mineralogical characteristics of ion-adsorption type REE mineralization in Phuket, Thailand. Miner Deposita, 48:437-451.

Santana, I.V. 2013. Caracterização mineralógica e geoquímica de ocorrência de terras raras no maciço granítico Serra Dourada, Goiás/Tocantins, Brasil. 82 folhas. Dissertação (Mestrado). Instituto de Geociências, Universidade de Brasília.

Santana, I. V.; BOTELHO, N. F. e WALL, F. 2015. Occurence and behaviour of monazite-(Ce) and xenotime- $(\mathrm{Y})$ in detrital and saprolitic environments related to the Serra Dourada granite, Goiás/Tocantins State, Brazil: potential for REE deposits. Journal of Geochemical Exploration, v. 155, p. 1-13.

Streckeisen, A. L., 1974. Classification and Nomenclature of Plutonic Rocks. Recommendations of the IUGS Subcommission on the Systematics of Igneous Rocks. Geologische Rundschau. Internationale Zeitschrift für Geologie. Stuttgart. Vol.63, p. 773-785.

Teixeira, L.M \& Botelho, N.F. 1999. Comportamento dos elementos terras raras pesadas em zircão, xenotima e torita de granitos e greisens da Subprovíncia Estanífera Paranã, Goiás. Revista Brasileira de Geociências, 29(4): 549-556. 
Teixeira, L.M. 2002. Caracterização de Minerais Portadores de Terras Raras e sua Aplicação à Petrologia e Geocronologia de Granitos das Subprovíncias Tocantins e Paranã - Goiás. Tese de Doutorado. Instituto de Geociências, Universidade de Brasília, 356p. 


\section{PARTE 2}

\section{ARTIGO}

(Artigo submetido ao Journal of Geochemical Exploration)

\section{MINERALOGIC AND GEOCHEMICAL CHARACTERIZATION OF RARE-EARTH OCCURRENCES IN THE SERRA DO MENDES MASSIF, GOIÁS, BRAZIL}

\section{ABSTRACT}

The Serra do Mendes granite massif (SMGM) is located in the Goiás tin province (GTP), which is characterized by A-type granite bodies that bear tin and associated rare earth elements (REEs). The Serra do Mendes massif is the largest granitic body in the Paranã subprovince and has three main facies belonging to the Pedra Branca Granite Suite (PB). This suite has ages of 1.77 to $1.74 \mathrm{Ga}$, a subalkaline to alkaline tendency and high concentrations of $Z r, Y$ and REE.

Samples of fresh rock, saprolite and alluvial sediments were collected from the most abundant facies, biotite monzogranite (PB1a) and leucomonzogranite (PB1c), with the objective of characterizing the REE-bearing minerals and their concentrations. The analytical techniques included petrography, scanning electron microscopy, mineral chemistry analysis with an electron probe micro-analyzer (EPMA) and total rock geochemistry.

The most evolved facies, PB1c contains the highest concentrations of REE-bearing minerals, the most noteworthy of which are fluocerite-Ce, REE oxyfluorides, bastnaesite, monazite, allanite, solid solutions of thoritezircon, fluorite and apatite.

REE contents in the most abundant facies, PB1a, range from 363.8-985.9 ppm, and its saprolite contains concentrations of 60 to $1283.9 \mathrm{ppm}$ with LaN/YbN ratios between 4 and 17.7\%. Facies PB1c contains REEs at concentrations between 460.9 and 958.6 ppm, and its saprolites contain concentrations of REEs of 495.7 and $902.1 \mathrm{ppm}$. The LaN/YbN ratios in the rocks and saprolites are between 2 and 12.3\%. Along with the REE minerals, it is noteworthy the occurrence of zircon and thorite with up to $20 \% \mathrm{REE}_{2} \mathrm{O}_{3}+\mathrm{Y}_{2} \mathrm{O}_{3}$.

These values together with factors such as the climate and morphology of the study area make the Serra do Mendes granite massif an important area for prospecting and exploration for REE.

KEY WORDS: REE bearing minerals, Serra do Mendes Granite Massif, weathering 


\subsection{INTRODUCTION}

Rare earth elements (REE) are important materials in high technology and are consequently strategic resource in the 21 st century. With the global increase in demand for REEs, the study of and exploration for these resources have increased and attracted international interest. Although REE are relatively abundant in the earth's crust, deposits of economic interest are rarer, andscarce and are randomly distributed in a few countries, notably China, United States, Australia, Russia, Brazil, India, Malaysia, South Africa and Thailand. The largest percentages of economically important REE deposits are located in China.

In general, based on the embedding material, REE deposits can be classified into the following types (Kanazawa and Kamitami, 2006; Wang et al., 2015, Bgs, 2011): carbonatites, alkaline compounds, weathered soils and hydrothermalized skarns. REE deposits associated with the weathering of granitic rocks are not common. There are few granite bodies that contain significant concentrations of REE, although this type of rock is common in the Earth's crust. Factors such as the tropical climate play an important role in the development of REE deposits of supergenic type such the case of deposits associated with weathering profiles of China. The distribution of this type of deposit in addition to a few prospects in China,and southern Thailand is in the research and exploration stage (Wu et al., 1990; Bao and Zhao, 2008; Chi and Tian, 2009; Yang et al., 2013, Sanematsu et al., 2009, 2013, Ibrahim et al., 2015 ). In Brazil, Marini et al. (1992) drew attention to the importance of REE concentrations in granitic rocks with economic potential. This study gave rise to exploration targets in granites of the Goiás Tin Province and a first prospect for REE deposits of the ionic-adsorption type in clay, the Serra Verde project, is in the final phase of research in the Serra Dourada granite massif (Rocha et al., 2013; Santana et al., 2014).

The Serra do Mendes granite massif (SMGM) is petrogenetically and mineralogically similar and is located in the same geological context of the Serra Dourada granite- They are important for the REE exploration do to relative high concentrations in saprolites and weathering profiles.

\subsection{GEOLOGIC CONTEXT}

The SMGM is part of the Goiás Tin Province (GTP), which consists of four subprovinces where tin-bearing granite massifs with associated REEs are located (Marini and Botelho, 1986, Marini et al., 1992). The GTP consists of approximately 20 granitic bodies and pegmatite veins of Paleoproterozoic to Neoproterozoic age that intruded or were overlapped by metasedimentary rocks of the Serra da Mesa, Araí, and Paranoá groups and Ticunzal Formation. 
The two main subprovinces belonging to the GTP are located in the northern portion of the state of Goiás and in the southern tip of the state of Tocantins. Figure 9a shows the location of the Tocantins Subprovince (TSP) in the west, where the main targets of exploration for rare earth deposits are hosted in the Serra Dourada massif, and the Paranã Subprovince (PSP) in the east, where the SMGM is located.

The Paranã subprovince consists of the Pedra Branca, Mocambo, Mangabeira, Mendes and Sucurí granites. All these granites are A-type and are part of the granitic unit called the Pedra Branca (PB) Suite, which is composed of PB1 and PB2 granites with ages between 1.77 and $1.74 \mathrm{Ga}$. These A-type granites intruded the Aurumina Suite and/or the Ticunzal Formation, located in the external portion of the Brasilia Belt (Alvarenga et al., 2007). The exposures of these granite bodies generally form domed topography that stands out from the subdued relief underlain by the surrounding rocks (Marini and Botelho, 1986 and Marini et al., 1992).

\subsubsection{Serra do Mendes Granite Massif}

The SMGM is exposed in an elliptical area with its $15 \mathrm{~km}$ long major axis trending NE, and its minor axis being approximately $10 \mathrm{~km}$ long, which makes the SMGM the largest granitic body in the PSP. It is little known because it is not an important source of tin. It consists mainly of a melanocratic biotite monzogranite with deformation mainly on the borders. In less-deformed regions, it is possible to observe graphic or micrographic/granophyric textures and euhedral to subhedral quartz crystals similar to those in rapakivi granites.

Biotite monzogranite (PB1a): Facies PB1a is the most abundant facies in the SMGM (Figure 9b). It consists of dark-colored, inequigranular, moderately foliated rocks with medium to thick phaneritic textures and local porphyritic texture and consists of $26 \%$ quartz, $21 \%$ microcline, $18 \%$ plagioclase, $14 \%$ biotite, $7 \%$ muscovite and $5 \%$ ilmenite. The most common accessory minerals are apatite, zircon, monazite, fluorite and allanite. In thin section, the subhedral ilmenite crystals with advanced reaction rims formed by titanite and graphic intergrowth textures stand out.

Syenogranite with fluorite and biotite (PB1b): Facies PB1b was mapped as a small body in the east-central portion of the SMGM. It displays medium to fine phaneritic texture, incipient foliation and the presence of fluorite in hand samples, which distinguishes it from the other facies of the Pedra Branca Suite. It contains 30\% quartz, 20\% orthoclase, 10\% plagioclase, $11 \%$ biotite, $14 \%$ muscovite and $10 \%$ fluorite as essential minerals and apatite, ilmenite and epidote as accessories. Its igneous characteristics are very well preserved, with granophyric texture being common. 

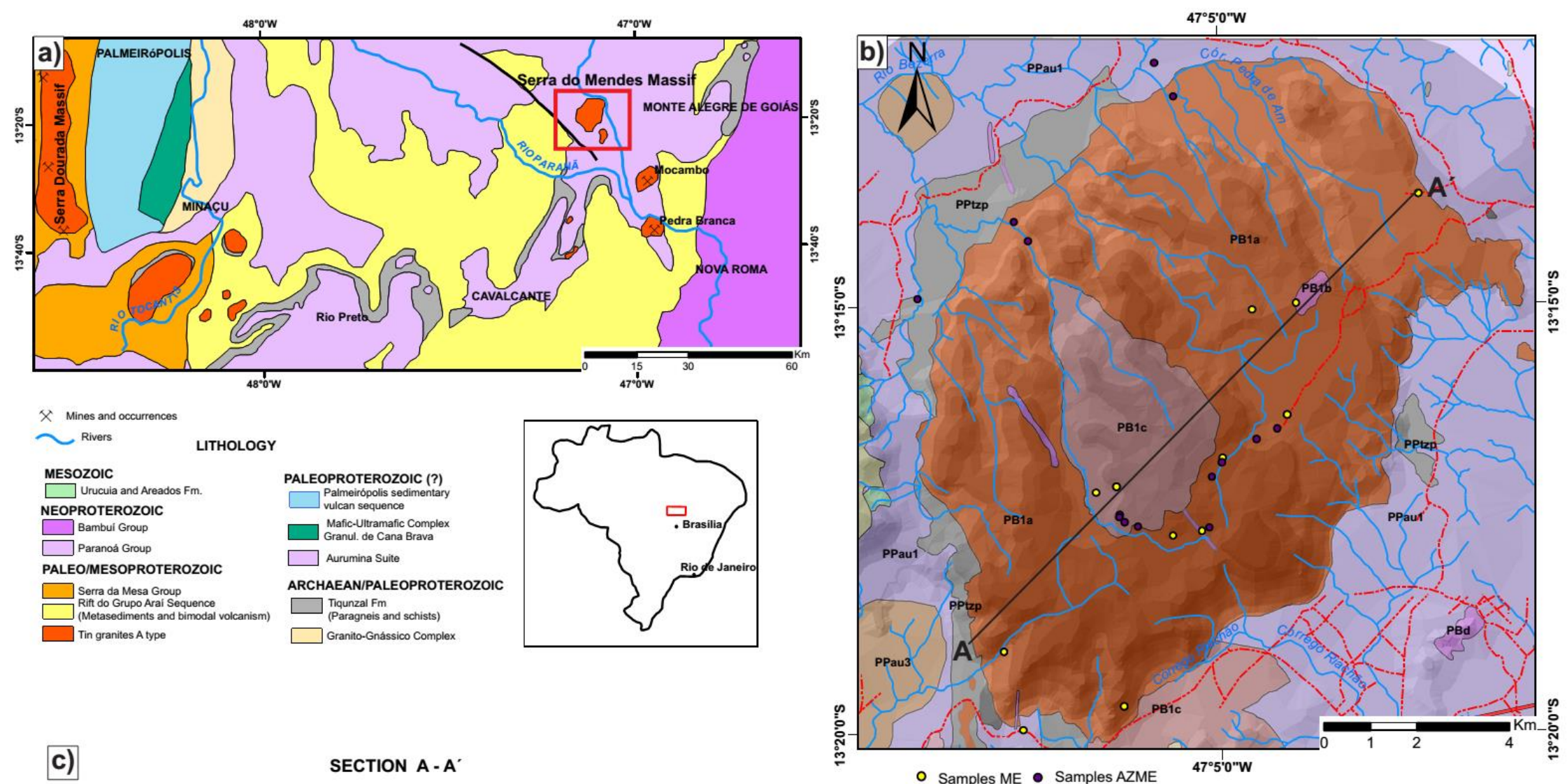
c)
SECTION A-A
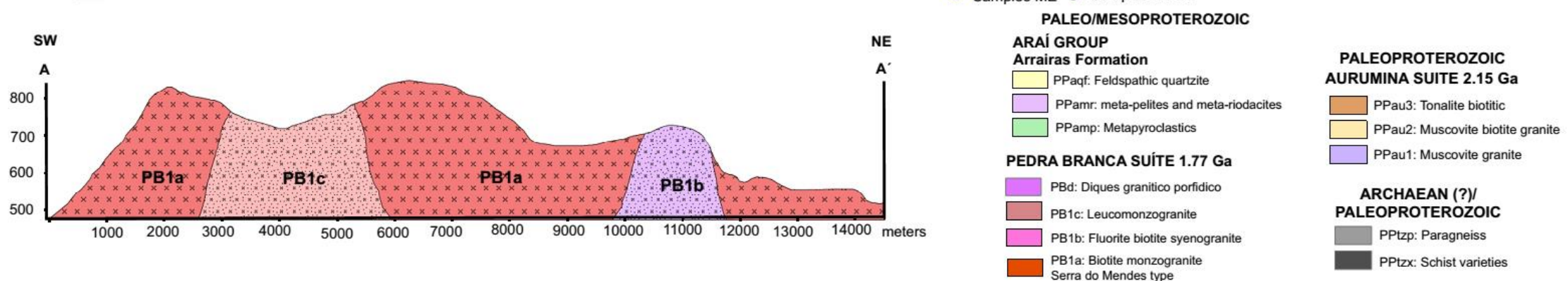

Figure 9. a) Schematic geological map of the northern part of the Goiás Tin Province, with the main granitic massifs with potential for REE and location of the SMGM (modified from Botelho and Moura (1998); b) local geological map and sampling locations in the SMGM (adapted from Alvarenga et al. 2007); c) schematic section $A-A$ : 
Leucomonzogranite (PB1C): Facies PB1c is located in the central part of the SMGM (Figure $9 b)$. It is also present as dikes located NE of the massif. The rocks are muscovitic leucomonzogranite composed of 35\% quartz, $25 \% \mathrm{~K}$-feldspar, $20 \%$ plagioclase, $12 \%$ muscovite and $4 \%$ fluorite. The accessory minerals include zircon, allanite, epidote, rutile and titanite.

Dikes of biotitic porphyritic granite with a dark matrix are present; K-feldspar and blue quartz crystals stand out. This rock has a monzogranitic composition, and its essential minerals are $30 \%$ quartz, 25\% K-feldspar, 20\% plagioclase and 15\% biotite. The secondary minerals are ilmenite, apatite, zircon, fluorite, titanite, calcite, muscovite and epidote. It displays a distinct mylonitic foliation.

\subsection{MATERIALS AND METHODS}

Field trips were made to the massif for geologic reconnaissance, sampling rocks, saprolite and alluvial heavy-mineral sands deposited by streams located within the massif. To pinpoint the best spots for sampling we counted on the aid of a gamaspectrometer, since the assemblage of heavy minerals include Th-U-bearing specimens such as monazite, and thorite. Also, the sampling sites were chosen based on the local geology, the slope of terrain and the magnitude of the streams.

\subsubsection{Electron Microprobe Analyses}

The compositions of the REE-bearing minerals were determined using a JEOL-JXA-8230M electron microprobe analyser (EPMA) in the Institute of Geosciences of the University of Brasilia, equipped with five vertical wavelength-dispersive spectrometers (WDS), one energydispersive spectrometer (EDS) and ZAF matrix correction. Both REE-minerals bearing were analyzed following the protocol of Scherrer et al. (2000). The advantage of this method is that no pre-measured correction factors are needed, the spectral lines and background positions are already set in order to avoid it. Analytical conditions were: take-off angle of $40^{\circ}, 25 \mathrm{kV}$ acceleration voltage; $50 \mathrm{nA}$ electron current and $3 \mu \mathrm{m}$ the diameter of the beam. Counting times were 20 s for the REE's and 10s for the other elements. Ka-lines were used for $\mathrm{P}, \mathrm{Al}, \mathrm{Si}, \mathrm{Ca}$ and $\mathrm{Fe}$. La-lines were considered for Y, La, Ce, Er, Yb. Lß-lines were used for $\mathrm{Pr}, \mathrm{Nd}, \mathrm{Sm}, \mathrm{Gd}, \mathrm{Tb}$, $D y, H o$. For $U, T h$, and $P b$ we used $M \beta, M \alpha$ and $M \beta$ respectively. Standards were the same as those employed for monazite analysis. The standards for the REE's were synthetic glasses; for $Y$ a synthetic oxide of $\mathrm{Fe}$ and $\mathrm{Y}$; natural oxides for the elements $U$ and Th and the mineral galena for $\mathrm{Pb}$. The elements $\mathrm{Ca}$ and $\mathrm{Si}$ were standardized with wollastonite; $\mathrm{P}$ with apatite. For supplementary detailed information on the background positions and integration times refer to Scherrer et al. (2000). 


\subsubsection{Scanning electron microscopy}

In order to identify accesory minerals, including REE bearing minerals, we employed a scanning electron microscopy (SEM) with energy dispersive X-ray spectrometry (EDS) after observation by plane-polarized ligh microscopy. Imaging and semi-quantitative analyses of REE-bearing minerals were performed using a FEI QUANTA 450- SEM-EDS systems at the Geoscience Institute Laboratory, University of Brasília. Imaging was carried out on carbon coated polished thin sections at an acelerating voltaje of $15 \mathrm{kV}$ and vean current of $33 \mathrm{nA}$.

\subsubsection{Whole-rock chemical analyses}

Eighteen representatives samples of rock, saprolite and stream sediments within the two main granitic facies in the Serra do Mendes massif were analyzed. Analyses of major, minor and trace elements were carried out by ACME Analitycal Laboratories Ltd (VancouverCanada). The abundances of major and minor elements were obtained by ICP-AEs and ICPMS after fusion of the sample with lithium metaborate. The sample powder of $0,200 \mathrm{~g}$ was mixed with lithium metaborate flux of $0,90 \mathrm{~g}$ and fused in a furnace at $1000^{\circ} \mathrm{C}$. The sample melt is cooled and dissolved in $100 \mathrm{ml}$ of $4 \% \mathrm{HNO}_{3}$ and/or $2 \% \mathrm{HCl}$ solution. This solution is analyzed by inductively coupled plasma mass spectrometry (ICP-MS).

\subsection{RESULTS}

\subsubsection{Mineralogic characterization}

The REE-bearing minerals in the SMGM, listed in order of REE abundance, are fluocerite$\mathrm{Ce}$, bastnaesita, REE oxyfluorides, monazite, allanite, solid solutions of thorite, zircon, and apatite. Table 1 presents the relative abundances of these minerals based on the granitic carrier facies and a summary of the amount (wt.\%) of REE, obtained using the EPMA. 
Table 1. Relative amounts of REE minerals in the SMGM granites and in the alluvial sediments (- no observed, +low ++ medium, +++ high, SS: solid solution) and the respective REE contents (wt. \%) obtained by EPMA.

\begin{tabular}{lcccccc}
\hline $\begin{array}{l}\text { REE- } \\
\text { bearing } \\
\text { minerals }\end{array}$ & $\begin{array}{c}\text { biotite } \\
\text { monzograni } \\
\text { te (PB1a) }\end{array}$ & $\begin{array}{c}\text { leucomonzogranite } \\
\text { (PB1c) }\end{array}$ & $\begin{array}{c}\text { Abundance } \\
\text { sediments }\end{array}$ & Min & Max & Average \\
\hline \hline Fluocerite-Ce & - & ++ & - & 74,6 & 80,4 & 77,3 \\
\hline Bastnasite & + & +++ & + & 55,2 & 78,2 & 66,8 \\
\hline $\begin{array}{l}\text { REE- } \\
\text { oxifluorides }\end{array}$ & + & ++ & 41,8 & 76,2 & 63,9 \\
\hline Monazite & +++ & ++ & ++ & 47,3 & 62,1 & 57,2 \\
\hline Allanite & ++ & ++ & - & 8,1 & 29,3 & 19,1 \\
\hline SS Th-Xe & +++ & +++ & ++ & 1,2 & 53,8 & 10,0 \\
\hline SS Th-Zr & +++ & +++ & ++ & 2,1 & 18,1 & 8,1 \\
\hline Zircon & +++ & ++ & +++ & 0,9 & 14,6 & 4,0 \\
\hline Apatite & ++ & - & ++ & 0,8 & 1,4 & 1,1
\end{tabular}

The most important characteristics of each mineral, the mineral chemistry and the REE concentrations are described below.

\section{Fluocerite-(Ce) ((Ce, La) F $F_{3}$}

The fluocerite crystals in the SMGM tend to be compositionally homogeneous, range in diameter from 10 to $40 \mu \mathrm{m}$ and are present mainly in the PB1c facies. This mineral varies slightly in its content of $\mathrm{LREE}_{2} \mathrm{O}_{3}$ (between 73.4 and $79.7 \%$ ). The concentrations of $\mathrm{HREE}_{2} \mathrm{O}_{3}+\mathrm{Y}_{2} \mathrm{O}_{3}$ are low or zero, i.e., below $2 \%$. The concentrations of Th are elevated in the fluocerite, where they reach up to $4.3 \%$, which makes Th the main impurity in the mineral and lends it metamictic characteristics.

Low $\mathrm{F}$ concentrations are also evident (11.9-16.7 wt.\%). Figure 10a and 10b shows the mineral relations between the fluocerite, fluorite and zircon and the chemical relationships between the $\mathrm{LREE}_{2} \mathrm{O}_{3}$ and $\mathrm{HREE}_{2} \mathrm{O}_{3}+\mathrm{Y}_{2} \mathrm{O}_{3}$ in the figure 12a. The REE pattern, normalized to the chondrite (Figure 12b), shows descending and approximately coincident curves of $\mathrm{La}$ to $\mathrm{Nd}$ and a small positive anomaly of Eu. This pattern is characterized by an important fractionation between the LREE and the HREE.

\section{Bastnaesite ((Ce, $\left.\mathrm{La}, \mathrm{Y}) \mathrm{CeO}_{3} \mathrm{~F}\right)$}

The bastnaesite crystals observed in the SMGM range in diameter from 20 to $200 \mu \mathrm{m}$ and are present as dendritic aggregates associated mainly with allanite masses and in contact with fluorite and mica (Figures 10c and 10d). They were observed in the most evolved 
leucomonzogranite facies (PB1c). Bastnaesite is a relatively rare mineral in the massif. According to Teixeira and Botelho (2006), who studied this mineral in the Serra Dourada massif and in the Paranã subprovince (PSP), bastnaesite was found only in hydrothermally altered rocks such as greisenized granites, greisens and albitites, or as a product of destabilization of allanite, as is the case of the bastnaesites analyzed in the SMGM, suggesting that it is a secondary mineral originating from the alteration of allanite due to hydrothermalism. In specific cases, bastnaesite occurs as well formed crystals, presenting contacts defined by fluorite.

According to the results from the EPMA, two types of bastnaesite were characterized, both in the same PB1c granite facies: one type rich in $\mathrm{Ce}$ and another type rich in $\mathrm{Y}$. The second type contains concentrations of $\mathrm{Y}_{2} \mathrm{O}_{3}$ of $14-19 \%$, which classifies it as bastnaesite- $(\mathrm{Y})$. The concentrations of $\mathrm{REE}_{2} \mathrm{O}_{3}+\mathrm{Y}_{2} \mathrm{O}_{3}$ in the bastnaesites- $(\mathrm{Ce})$ range from 58.6-84.6\%, and those in the bastnaesite- $(\mathrm{Y})$ are slightly lower, $56.8-63.7 \%$. The amounts of $\mathrm{HREE}_{2} \mathrm{O}_{3}+\mathrm{Y}_{2} \mathrm{O}_{3}$ in the bastnaesite-( $\mathrm{Y}$ ) vary from 23.5 to $35.8 \%$ and are below $2 \%$ in the bastnaesite-(Ce) (figure 12c). This difference in the HREE concentration is observed in the figure $12 \mathrm{~d}$, where the bastnaesite(Y) presents a nearly flat REE pattern.

\section{REE Oxyfluorides}

REE oxyfluorides were identified in the two main granitic facies of the SMGM, with greater abundance in facies PB1c. They are present as anhedral crystals with diameters between 50 and $150 \mu \mathrm{m}$, irregular edges, and associations mainly with fluorite, quartz and zircon. REE oxyfluorides were observed at the rims of zircon grains, probably formed by the alteration of REE minerals, such as monazite, included or in contact with the zircon crystal (figure 10e). They display decomposition textures such as those observed by Johan and Johan (1994) and Teixeira (2002), in which two phases of $\mathrm{La}$ and $\mathrm{Ce}$ and an intermediate phase between the two are observed, as verified via EDS (figure 10f).

The studied oxyfluorides contain 51-89\% $\mathrm{REE}_{2} \mathrm{O}_{3}+\mathrm{Y}_{2} \mathrm{O}_{3}$, particularly $\mathrm{LREE}_{2} \mathrm{O}_{3}$ (47-87\%). The concentrations of $\mathrm{F}$ vary from 5 to $9 \%$. Some grains are enriched in $\mathrm{HREE}_{2} \mathrm{O}_{3}+\mathrm{Y}_{2} \mathrm{O}_{3}(2-3 \%)$ and present an ascending REE pattern for the heavier REE (figures $12 \mathrm{e}$ and f). 

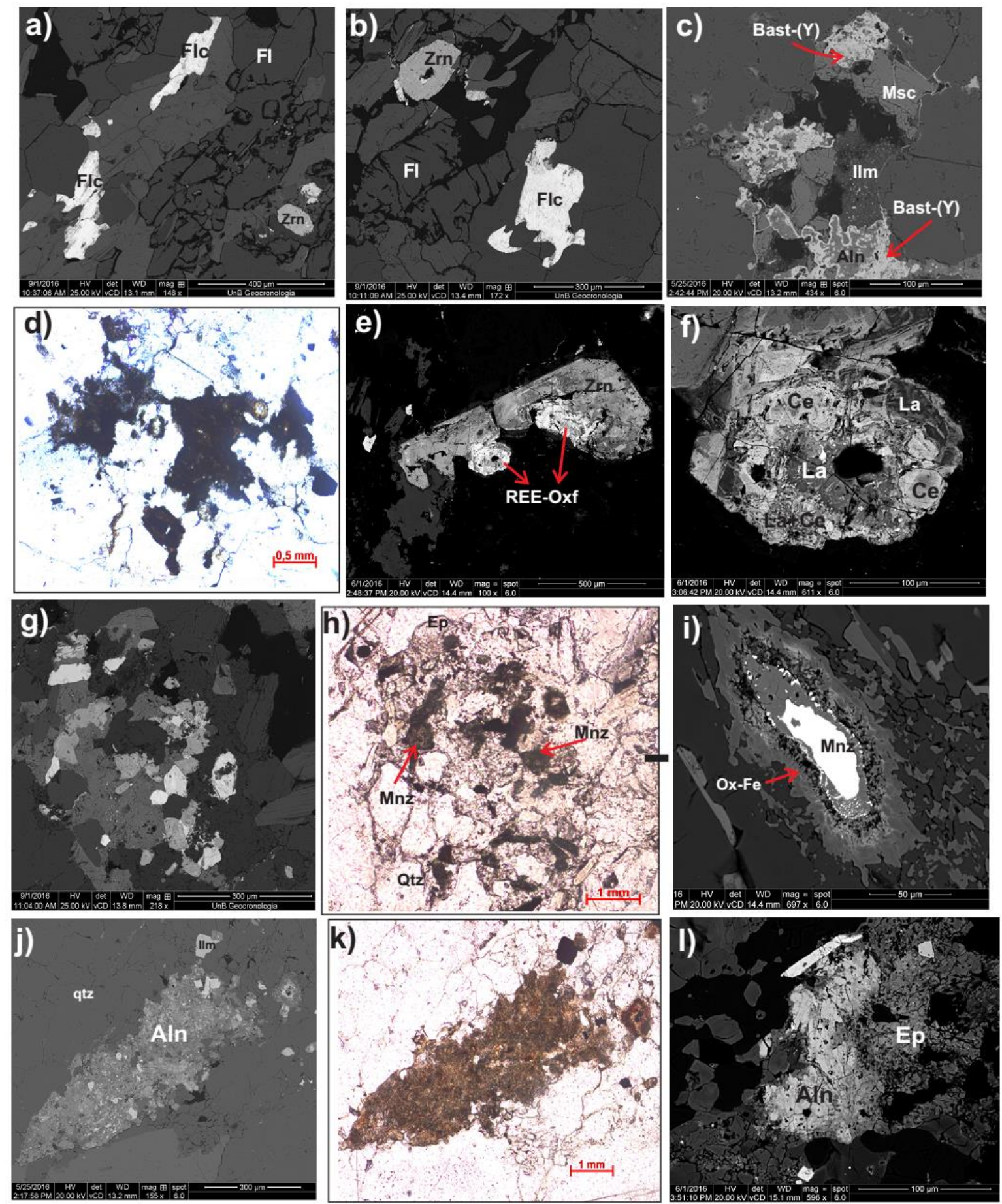

Figure 10. Optical and backscattered electron images (BSE) of REE bearing minerals from the SMGM. a) and b): fluocerite (Flc) associated with fluorite (FI) and zircon ( $\mathrm{rrn}$ ) in the leucomonzogranite (sample $A Z M E-4 B) ; c)$ and d) Bastnaesites associated with allanite (Aln), muscovite (Musc) and ilmenite (IIm) in the leucomonzogranite (sample ME10A); e) and f) oxyfluorides (REE-Oxf) associted with altered zircon in the leucomonzogranite. Light areas: Ce-rich; dark areas: La-rich (sample 05-I-164); g) and h): Monazite grains $(\mathrm{Mnz})$ in the biotite granite; i): BSE image of a monazite grain with reaction rim of $\mathrm{Fe}$-oxide $(\mathrm{Ox}-\mathrm{Fe}) ; \mathrm{j}), \mathrm{k}$ ) and I): allanite associated with epidote (ep) and ilmenite (ilm). 

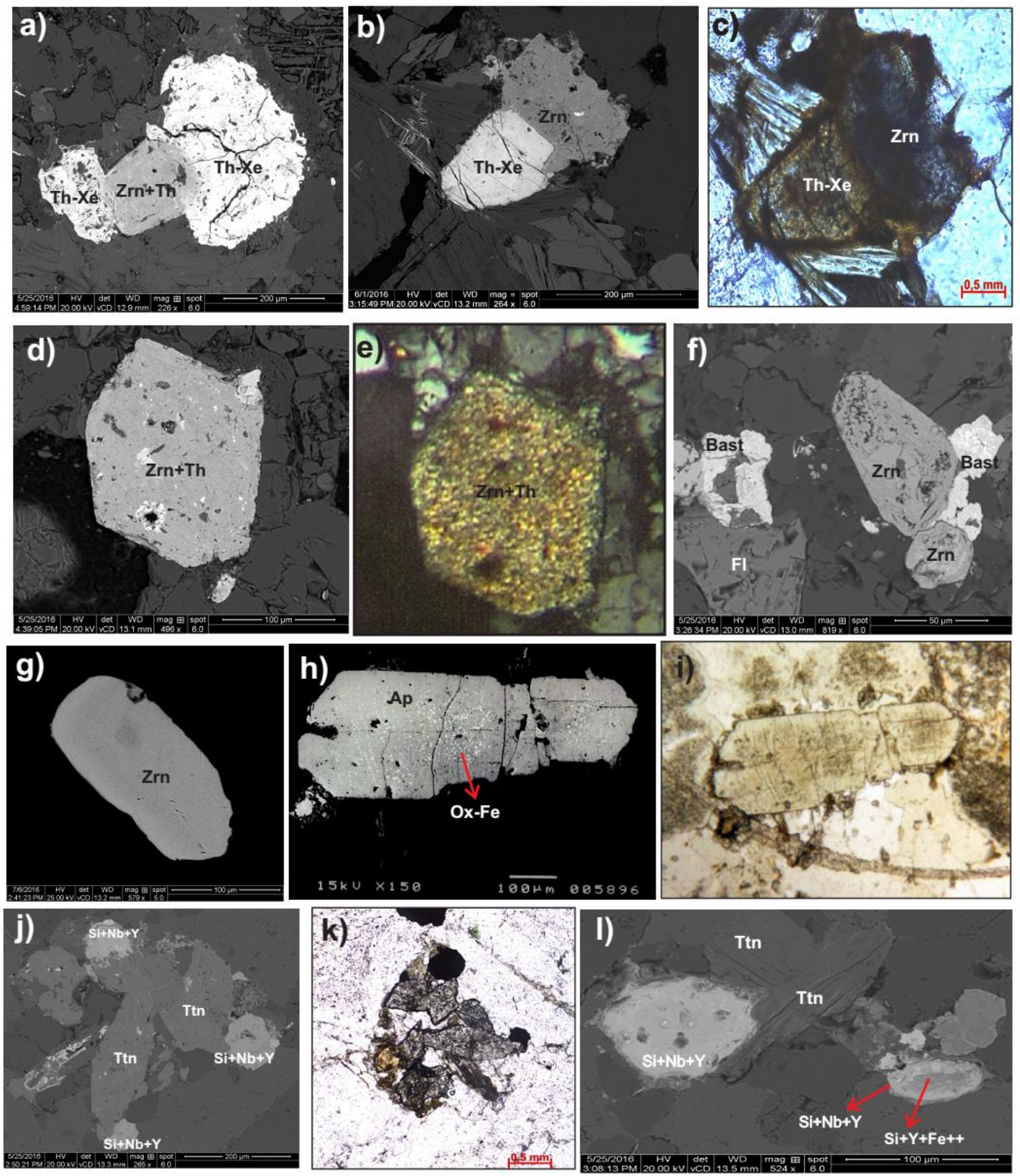

Figure 11. Optical and backscattered electron images (BSE) of REE bearing minerals in the SMGM, a),

b) and c): thorite - zircon- xenotime association in the biotite granite (sample AZME-7D) and in the leucomonzogranite; d), e), f) REE-bearing zircon associted with thorite (Th), bastnaesite (bast) and fluorite

(FI) in the leucomonzogranite (samples AZME 4A and ME-8C); g) zircon of the biotite granite (sample $A Z M E-12 B)$; h) and i) apatite grain in the biotite granite with Fe-oxide inclusions (white dots in h)); j), k) and I) Unidentified $\mathrm{Nb}$ - Si-Y-REE mineral in association with titanite (Ttn) agglomerates.

\section{Monazite-(Ce) ((Ce, La, $\left.\mathrm{Nd}, \mathrm{Th}) \mathrm{PO}_{4}\right)$}

Monazite is a common mineral in both granitic facies of the SMGM and is present mainly as isolated elongated grains ranging from 30 to $100 \mu \mathrm{m}$ in diameter. The grains commonly display reaction rims of ilmenite and epidote with, in some cases, inclusions of $\mathrm{Fe}$ oxides. Their reddish 
coloration is characteristic. The grains are spatially associated with biotite but seldom with quartz and feldspar (Figures 10g, 10h and 10i).

According to the EPMA results, the $\mathrm{REE}_{2} \mathrm{O}_{3}+\mathrm{Y}_{2} \mathrm{O}_{3}$ content is between 54.2 and $71.1 \%$. The, LREEs are typically abundant, at $52.4-69.8 \%$ (figures $12 \mathrm{~g}$ and $12 \mathrm{~h}$ ), the $\mathrm{La}_{2} \mathrm{O}_{3}$ content varies from 9.2 to $17.1 \%$, and the $\mathrm{Ce}_{2} \mathrm{O}_{3}$ content varies from 29.2 to $38.1 \%$. There are also high concentrations of $\mathrm{ThO}_{2}$ ranging from 2.0 to $10.1 \%$ and $\mathrm{CaO}$ and $\mathrm{F}$ concentrations that can reach $1.6 \%$.

According to $\mathrm{Ni}$ et al. (1995), monazite has the general formula $A B O_{4}$, where $A=R E E^{3+}, Y^{3+}$ $\mathrm{Th}^{4+}, \mathrm{U}^{4+}, \mathrm{Ca}^{2+}$, etc., and the tetrahedral site $\mathrm{B}$ is occupied by $\mathrm{P}^{5+}$ and $\mathrm{Si}^{4+}$. Substitutions (1), (2), (3) and (4) are the main substitutions observed in monazite, and the corresponding minerals are cheralite, huttonite, coffinite and xenotime, respectively.

$$
\begin{aligned}
& \mathrm{Ca}^{2+}(\mathrm{A})+\mathrm{Th}^{4+}(\mathrm{A}) \rightleftharpoons 2 \mathrm{REE}^{3+}(\mathrm{A}) \\
& \mathrm{Th}^{4+}(\mathrm{A})+\mathrm{Si}^{4+}(\mathrm{B}) \rightleftharpoons \mathrm{REE}^{3+}(\mathrm{A})+\mathrm{P}^{5+}(\mathrm{B}) \\
& \mathrm{U}^{4+}(\mathrm{A})+\mathrm{Si}^{4+}(\mathrm{B}) \rightleftharpoons \operatorname{REE}^{3+}(\mathrm{A})+\mathrm{P}^{5+}(\mathrm{B}) \\
& (\mathrm{REE}, \mathrm{Y})^{3+}(\mathrm{A}) \rightleftharpoons \operatorname{LREE}^{3+}(\mathrm{A})
\end{aligned}
$$

According to the diagram proposed by Linthout (2007), in which monazite, huttonite and cheralite are end members (Figure 12i), the studied mineral plots in the monazite field but can contain up to $20 \%$ huttonite $\left(\mathrm{ThSiO}_{4}\right)$ and $5 \%$ cheralite $\mathrm{CaTh}\left(\mathrm{PO}_{4}\right)_{2}$. The main substitution reactions acting on the SMGM monazite are represented by equations (1) and (2).

\section{Allanite-(Ce) ((Ca, Ce, $\left.\mathrm{Y}, \mathrm{La}) 2\left(\mathrm{Al}, \mathrm{Fe}^{+3}\right)_{3}(\mathrm{SiO})_{3}(\mathrm{OH})\right)$}

The SMGM allanite displays xenomorphic texture and is present as aggregates with epidote in all granite facies. An allanite+epidote+bastnaesite association is also common. It contains $\mathrm{REE}_{2} \mathrm{O}_{3}+\mathrm{Y}_{2} \mathrm{O}_{3}$ at concentrations (wt. \%) of 9.4-32.6\%; the $\mathrm{LREE}_{2} \mathrm{O}_{3}$ concentrations are between 9.0 and $31.5 \%\left(\mathrm{Ce}_{2} \mathrm{O}_{3}\right.$ at 5.1 to $\left.20.1 \%\right)$, and the $\mathrm{HREE}_{2} \mathrm{O}_{3}+\mathrm{Y}_{2} \mathrm{O}_{3}$ content can reach up to $4.6 \%$ and the concentrations of $\mathrm{SiO}_{2}$ (wt.\%) 25,6 to 33.2 (figures $13 \mathrm{a}$ and $13 \mathrm{~b}$ ). Its $\mathrm{TiO}_{2}$ content can reach $2.4 \%$. The REE values of allanites normalized to the chondrite, present a descending pattern (figure 13c).

Figures $10 \mathrm{j}, 10 \mathrm{k}$, and $10 \mathrm{l}$ show BSE and optical microscopy images of the allanites and their relationship with epidote; an imbalance is evident between the phases. Brighter gray colors represent sites where allanite is concentrated and the REE content is significant, and dark areas represent destabilization to epidote with no REE. 
a)

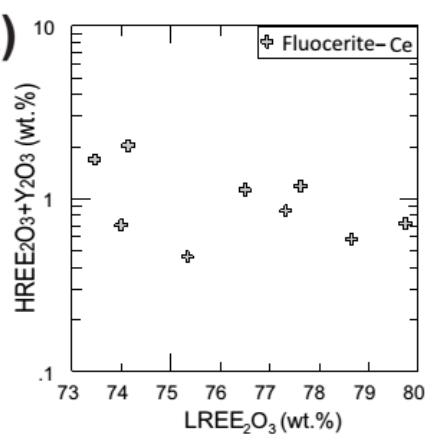

c)

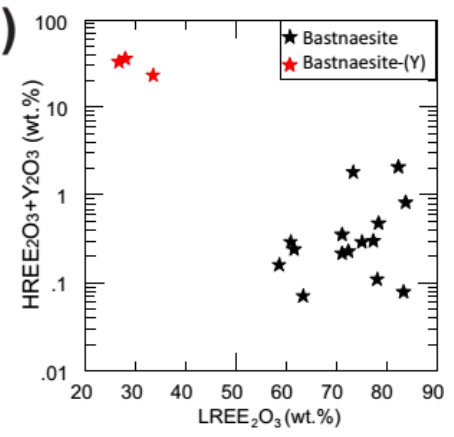

e)

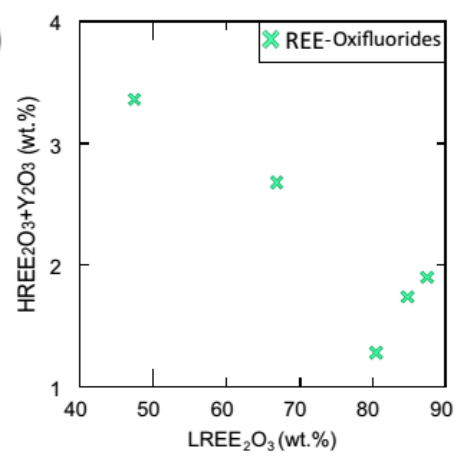

b)

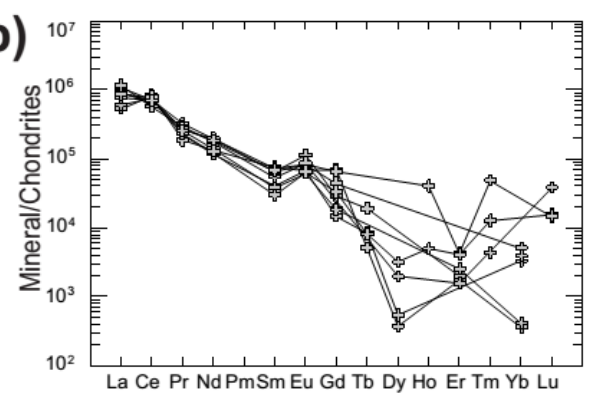

d)
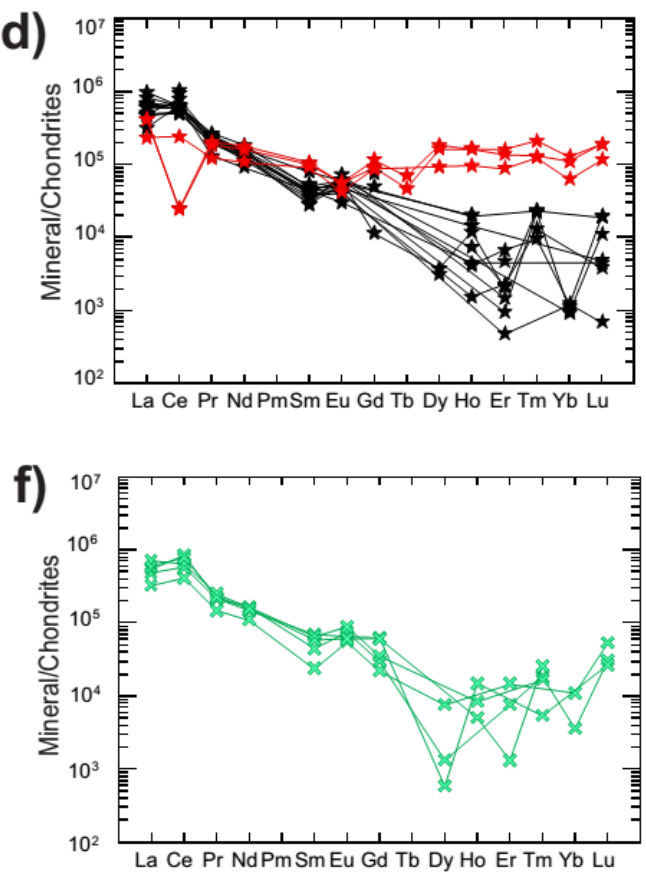

g)

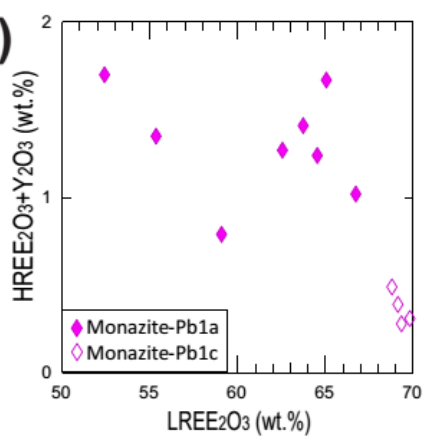

h)

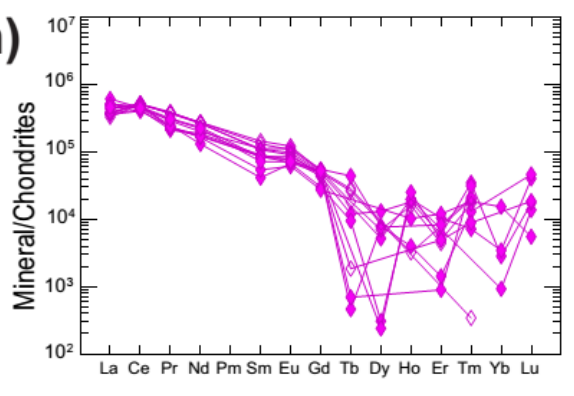

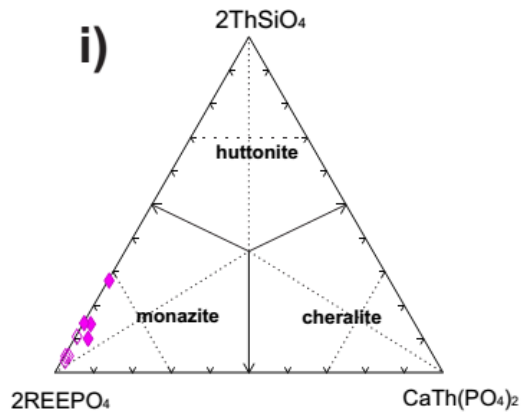

Figure 12. a) to h): Mineral chemistry plots and respective chondrite normalized REE patterns with normalization values from Sun \& McDonough (1989) for REE-bearing minerals in the SMGM; i) Diagram of Linthout, (2007) showing the compositional variation of the SMGM monazites in the system $2 \mathrm{REEPO}_{4}-\mathrm{CaTh}\left(\mathrm{PO}_{4}\right)_{2}-2 \mathrm{ThSiO}_{4}$. 

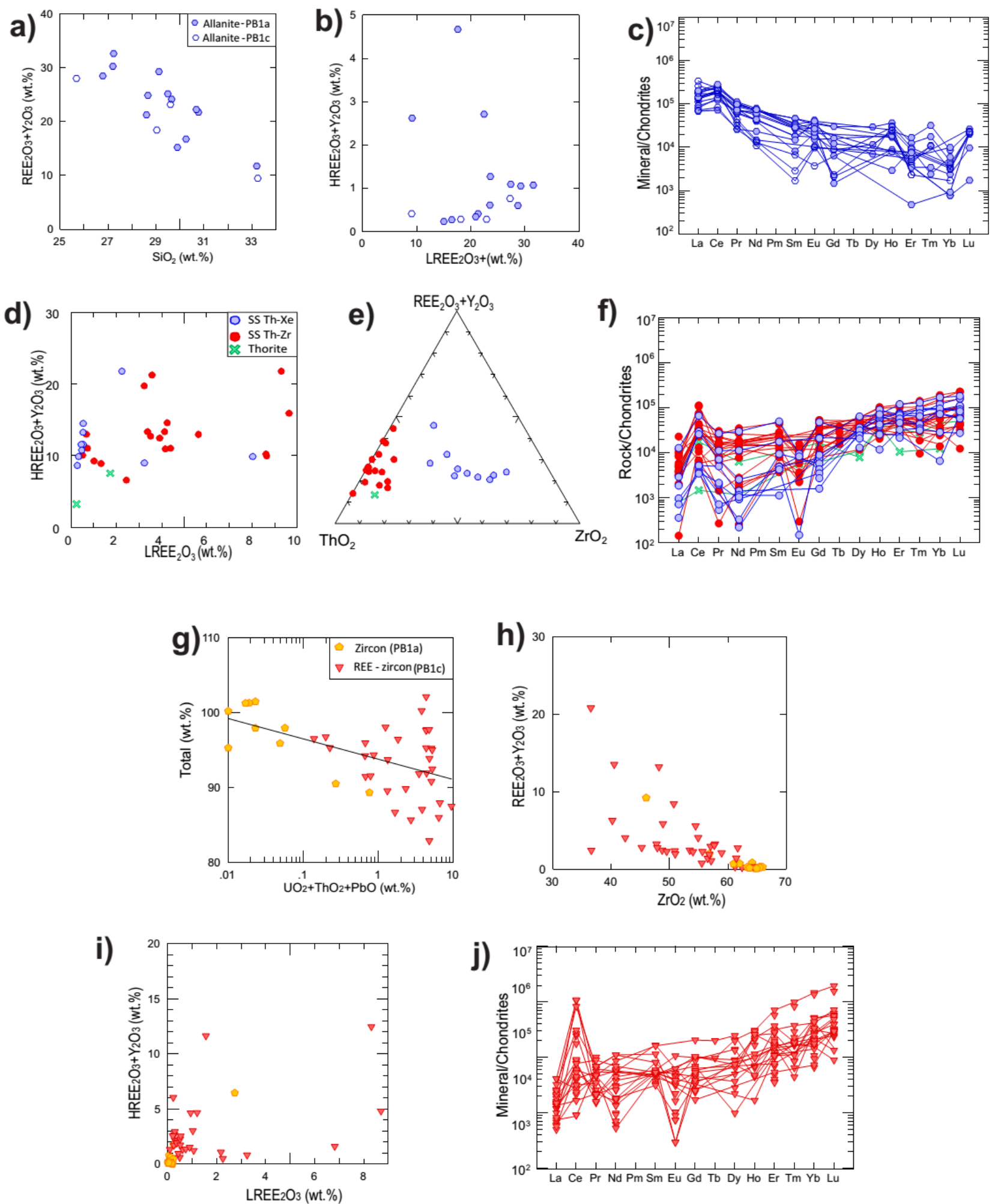

Figure 13. Mineral chemistry plots and respective chondrite normalized REE patterns with normalization values from Sun \& McDonough (1989) for REE-bearing minerals in the SMGM. a) to c): allanite; d) to f): thorite $(T h)$ - xenotime $(R E E+Y)$ - zircon (Zr) solid solutions;g) to i): zircon;i) j) REE patterns for the PB1c zircons. 

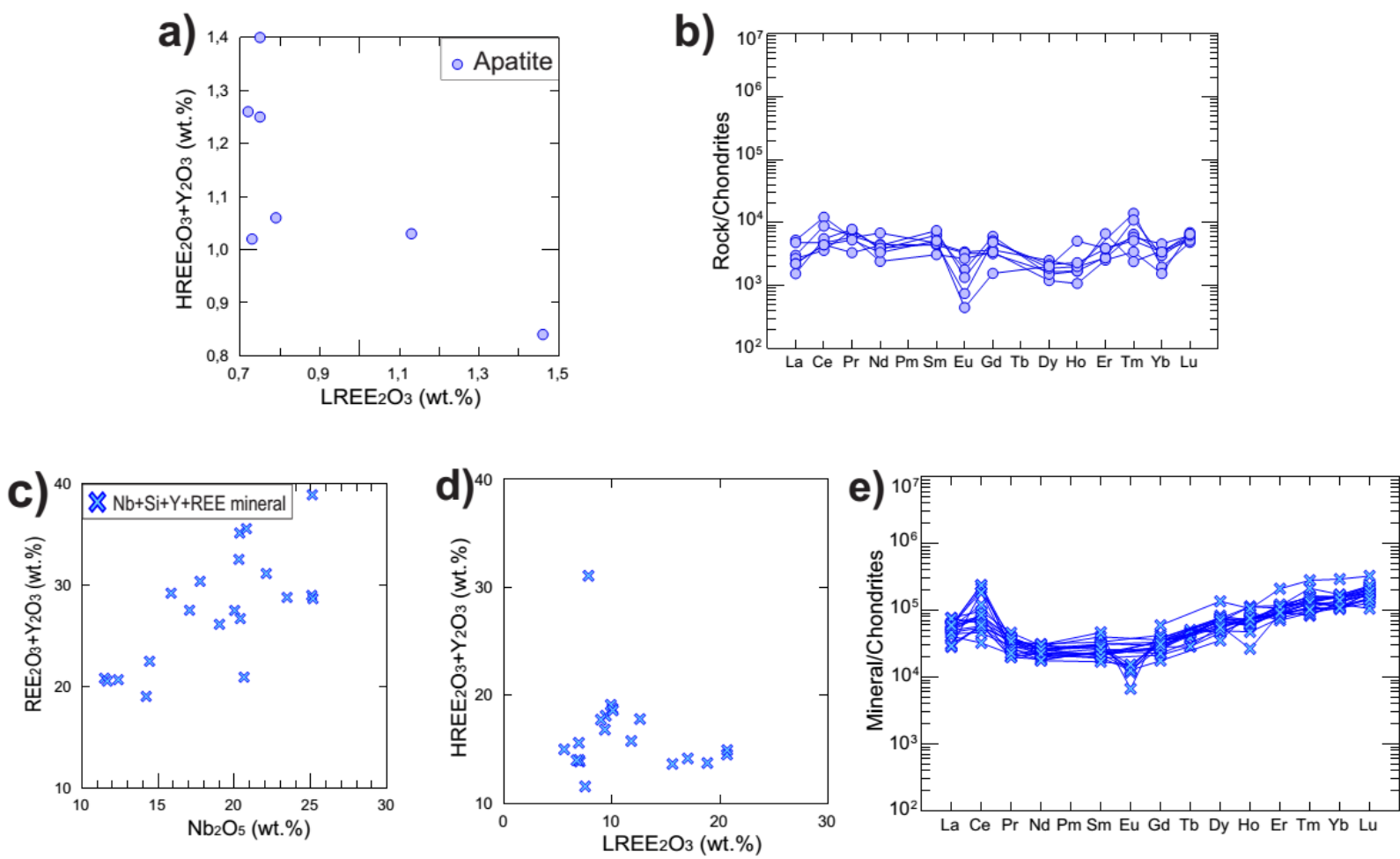

Figure 14. Mineral chemistry plots and respective chondrite normalized REE patterns with normalization values from Sun \& McDonough (1989) for REE-bearing minerals in the SMGM. a) and b): apatite; c) to e): unidentified Nb-Si-Y-REE rich mineral.

\section{Solid Solutions of Thorite}

The thorite grains identified in the SMGM are spatially associated with zircon. Their diameters range from 10 to $150 \mu \mathrm{m}$, and they were observed in the two granite facies (Figures $11 \mathrm{a}, 11 \mathrm{~b}$ and 11c,). According to the EPMA analyses, the thorites are present mainly in the form of solid solutions (SS). The most abundant is a thorite-xenotime SS followed by a thorite-zircon SS.

Compositionally, the thorite-xenotime SS contains $\mathrm{REE}_{2} \mathrm{O}_{3}+\mathrm{Y}_{2} \mathrm{O}_{3}$ at concentrations ranging from 9.0 to $31.1 \%\left(\mathrm{LREE}_{2} \mathrm{O}_{3}\right.$ at $<9.6 \%$ and $\mathrm{HREE}_{2} \mathrm{O}_{3}+\mathrm{Y}_{2} \mathrm{O}_{3}$ at $\left.3-23 \%\right)$. It contains significant concentrations of $\mathrm{Y}_{2} \mathrm{O}_{3}$ and $\mathrm{P}_{2} \mathrm{O}_{3}(4.7-12.6 \%$ and up to $8.8 \%$, respectively), which means that it is classified as a thorite-xenotime SS. The thorite-xenotime SS contains 27.9 to $54.9 \% \mathrm{ThO}_{2}$, which corresponds to 39.9 to $72 \mathrm{~mol} \%$ of $\mathrm{ThSiO}_{4}$.

The thorite-zircon SS is characterized by $\mathrm{ZrO}_{2}$ concentrations ranging from 2.5 to $29.5 \%$, $\mathrm{Y}_{2} \mathrm{O}_{3}$ at concentrations of 6.1 to $12.3 \%$ and $\mathrm{REE}_{2} \mathrm{O}_{3}+\mathrm{Y}_{2} \mathrm{O}_{3}$ at concentrations between 8.9 and $24.0 \%\left(\mathrm{LREE}_{2} \mathrm{O}_{3}\right.$ at $<4.3 \%$ and $\mathrm{HREE}_{2} \mathrm{O}_{3}+\mathrm{Y}_{2} \mathrm{O}_{3}$ at $\left.8.6-21.7 \%\right)$. 
Figure $13 \mathrm{~d}$ shows graphs of the SS mineral chemistry of the Serra do Mendes thorites, $\mathrm{LREE}_{2} \mathrm{O}_{3}$ vs $\mathrm{HREE}_{2} \mathrm{O}_{3}+\mathrm{Y}_{2} \mathrm{O}_{3}$; Figure $13 \mathrm{e}$ shows the two predominant trends of the Th- $\mathrm{Xe}$ and Th- $\mathrm{Zr}$ SSs and the similar $\mathrm{REE}_{2} \mathrm{O}_{3}+\mathrm{Y}_{2} \mathrm{O}_{3}$ concentrations in the 2 solid solutions. Figure 13f) shows a diagram of the SSs analyzed in relation to the chondrite of Sun and McDonough (1989).

\section{Zircon-ZrSiO $_{4}$}

The zircons in the SMGM differ morphologically and compositionally between the two main granite facies. In the facies PB1a (biotite monzogranite), the zircon grains are subrounded, with lengths ranging from 100 to $200 \mu \mathrm{m}$ and width-length ratios of $1: 1$ and 1:2. They are optically and compositionally homogeneous. The zircons from PB1c range from pink to brown in color and 50-150 $\mu \mathrm{m}$ in diameter and have 1:3 width-length ratios; they are translucent to opaque indicating some degree of metamictization and are enriched in REE (Figures 11d, 11e and 11f ).

The EPMA analyses of the zircons with homogeneous composition show that the amounts of $\mathrm{ZrO}_{2}$ are between 50.8 and $60.9 \%$, the $\mathrm{SiO}_{2}$ content is between 26.5 and $33.3 \%$, and the $\mathrm{HfO}_{2}$ concentrations are between 1.10 and $3.2 \%$. The concentration of $\mathrm{REE}_{2} \mathrm{O}_{3}+\mathrm{Y}_{2} \mathrm{O}_{3}$ can reach $2.3 \%\left(\mathrm{HREE}_{2} \mathrm{O}_{3}+\mathrm{Y}_{2} \mathrm{O}_{3}\right.$ at $\left.<1.9 \%\right)$. Most of these analyses correspond to facies PB1a and detrital zircons. In the EPMA results, some of the totals are less than $100 \%$, which is attributed to water within the zircon at concentrations as high as $10.5 \%$ due to the mectamitization (Figure $13 \mathrm{~g})$ and hydrothermal alterations of the mineral.

In the zircons of facies $\mathrm{PB} 1 \mathrm{c}$, the $\mathrm{SiO}_{2}$ content varies from 19.6 to $32.5 \%$, that of $\mathrm{ZrO}_{2}$ is between 36.4 and $61.6 \%$, that of $\mathrm{ThO}_{2}$ is $0.3-9.0 \%$ and that of $\mathrm{P}_{2} \mathrm{O}_{5}$ is $<4.1 \%$. The $\mathrm{REE}_{2} \mathrm{O}_{3}+\mathrm{Y}_{2} \mathrm{O}_{3}$ concentration is between 1.9 and $20.7 \%$, with $\mathrm{HREE}_{2} \mathrm{O}_{3}+\mathrm{Y}_{2} \mathrm{O}_{3}$ concentrations between 0.55 and $12.4 \%$ and $\mathrm{LREE}_{2} \mathrm{O}_{3}$ concentrations between 0.2 and $8.7 \%\left(\mathrm{Ce}_{2} \mathrm{O}_{3}\right.$ can reach 7.8\%). (Fig. 13h and 13i). In the diagram normalized to chondrite (figure 13j), a positive trend for HREE is observed in zircons of the facies PB1c.

\section{Apatite- $\mathrm{Ca}_{5}\left(\mathrm{PO}_{4}\right)_{3} \mathrm{~F}$}

Apatite is the main accessory mineral in the biotite monzogranite and occurs as colorless, subrounded grains of various sizes between 100 and $700 \mu \mathrm{m}$. Small crystals are present as inclusions within biotite, thereby forming pleochroic halos. According to the BSE images, the apatite crystals are chemically homogeneous and do not present zoning or evidence of alteration. Some apatite crystals contain small inclusions of Fe oxides (figures $11 \mathrm{~h}$ and 11i). 
The SMGM apatite is of the fluorapatite variety and contains $\mathrm{P}_{2} \mathrm{O}_{5}$ and $\mathrm{CaO}$ at concentrations between 39.9 and $41.2 \%$ and 48.0 and $52.8 \%$, respectively and the $\mathrm{F}$ concentrations is between 3.4 and 4.5 (wt.\%). It also contains $\mathrm{SiO}_{2}$ at $<1.2 \%$ and $\mathrm{Y}_{2} \mathrm{O}_{3}$ at $<0.9 \%$. The $\mathrm{REE}_{2} \mathrm{O}_{3}+\mathrm{Y}_{2} \mathrm{O}_{3}$ concentrations are between 1.1 and $3.3 \%$, the $\mathrm{Ce}_{2} \mathrm{O}_{3}$ content can reach $0.8 \%$, and the $\mathrm{HREE}_{2} \mathrm{O}_{3}+\mathrm{Y}_{2} \mathrm{O}_{3}$ content is less than $1.7 \%$ (figure 14a). The studied apatites has flat REE patterns (figure 14b).

\section{Unidentified Nb-Si-REE Mineral}

In sample ME-10A, under isotropic polarization, reddish grains with a rounded habit and diameters ranging from 20 to $50 \mu \mathrm{m}$ were observed. They are spatially associated with fluorite, muscovite, plagioclase and aggregates of titanite. The mineral characteristics under optical microscopy are similar to those of monazite, but the EPMA analysis indicates that it is compositionally different (Figure 11j, 11k and 111).

According to the EPMA analyses, this mineral is an $\mathrm{Nb}+\mathrm{Y}$ silicate with significant $\mathrm{Fe}$ and REE concentrations and slight enrichment in $\mathrm{HREE}_{2} \mathrm{O}_{3}+\mathrm{Y}_{2} \mathrm{O}_{3}$. The content of $\mathrm{SiO}_{2}$ is between 9.7 and $19.1 \%$, that of $\mathrm{Nb}_{2} \mathrm{O}_{5}$ is between 11.4 and $25.1 \%$, that of $\mathrm{Y}_{2} \mathrm{O}_{3}$ is between 5.4 and $13.5 \%$, the $\mathrm{FeO}$ content is in a wider range between 2.6 and $17.9 \%$, and the $\mathrm{TiO} 2$ content is $<6.1 \%$. The $\mathrm{REE}_{2} \mathrm{O}_{3}+\mathrm{Y}_{2} \mathrm{O}_{3}$ concentration is between 19.7 and $38.9\left(\mathrm{HREE}_{2} \mathrm{O}_{3}+\mathrm{Y}_{2} \mathrm{O}_{3}\right.$ at 11.5$31.0 \%$ and $\mathrm{LREE}_{2} \mathrm{O}_{3}$ at $5.5-20.6 \%$ ). The mineral also contains $\mathrm{UO}_{3}$ at concentrations as high as $5.28 \%$. These concentration totals are less than $100 \%$, specifically, between 63.3 and $89.9 \%$.

According to Figure $14 \mathrm{c}$, the greater $\mathrm{Nb}_{2} \mathrm{O}_{5}$ concentrations are directly related to the greater amount of $\mathrm{REE}_{2} \mathrm{O}_{3}+\mathrm{Y}_{2} \mathrm{O}_{3}$. Figure 14d shows that the $\mathrm{LREE}_{2} \mathrm{O}_{3}$ and $\mathrm{HREE}_{2} \mathrm{O}_{3}+\mathrm{Y}_{2} \mathrm{O}_{3}$ concentrations are similar and generally do not exceed $20 \%$. Figure $14 \mathrm{e}$ ), shows the mineral normalized to chondrite, with a homogeneous tendency for both LREEs and HREEs, with a positive Ce anomaly. The plot shows slightly greater concentrations of HREEs.

\subsubsection{Geochemistry of REE in granites, saprolites and alluvial sediments}

Whole-rock chemical compositions of the SMGM samples are listed in table 2.The REE contents of the biotite monzogranite (PB1a) range from 363.8 to $985.9 \mathrm{ppm}$ (LREEs at 327.3$891.7 \mathrm{ppm}$ and HREEs at 35-112.5 ppm). La, $\mathrm{Ce}$ and $\mathrm{Nd}$ are the most abundant, with concentrations of up to 206.0, 440.4 and 187.6 ppm, respectively. The HREEs Gd, Dy, Er and $\mathrm{Yb}$ are present at concentrations of up to $34.5,29.5,17.7$ and $14.8 \mathrm{ppm}$, respectively. The $\mathrm{LaN} / \mathrm{YbN}$ ratio is between 7.2 and 12.5 . 
The saprolites of the PB1a granite facies contain REEs at concentrations between 60 and $1283.9 \mathrm{ppm}$ (LREEs at 51.6-1232.7 ppm and HREEs at 8.4 and $73.7 \mathrm{ppm}$ ). La (160.2 ppm), Ce (23.8-889.2 ppm) and $\mathrm{Nd}(12.0-152.0 \mathrm{ppm})$ are the most abundant LREEs, and Gd (2.10-23.4 ppm), Dy (2.10-19.4 ppm), Er (6.5-12.9 ppm) and $\mathrm{Yb}$ (1.67-11.2 ppm) are the most abundant HREEs. The LaN/YbN ratio is between 4.0 and 17.7.

The leucomonzogranite PB1c contains REEs at concentrations between 460.9 and 958.6 ppm (LREEs at 339.2 and 761.4 ppm and HREEs at 121.6 and $197.2 \mathrm{ppm}$ ). La (92.8-200.7 ppm), Ce (151.0-334.2 ppm) and Nd (63.6-147.4 ppm) are the most abundant LREEs, and Gd (21.2-40.3 ppm), Dy (30.5-51.0 ppm), Er (23.9-35.2 ppm) and Yb (30.2-39.7 ppm) are the most abundant HREEs. The LaN/YbN ratio is between 2.0 and 3.4. indicating a relatively high enrichment of the HREE in relation to the HREE.

The saprolites of facies PB1c contain REEs at concentrations between 495.7 and 902.1 ppm (LREEs at 464.0 and 833.5 ppm and HREEs at 31.7 and $120.8 \mathrm{ppm}$ ). La (80.8-273.7 ppm), Ce (284.9-403.7 ppm) and Nd (67.1-166.3 ppm) are the most abundant LREEs, and Gd (10.1-18.5 ppm), Dy (8.2-27.2 ppm), Er (4.6-23.7 ppm) and $\mathrm{Yb}$ (4.4-31.5 ppm) are the most abundant HREEs. The LaN/YbN ratio is between 2.7 and 12.3, indicating a relatively high enrichment of the HREE in relation to the HREE

In the alluvial sediments, REEs are present at concentrations between 94.7 and $481.6 \mathrm{ppm}$, with LREE concentrations between 83.9 and $419.1 \mathrm{ppm}$ and HREE concentrations between 10.8 and 62.4 ppm. La (19.3-72.3 ppm), Ce (39.8 and 269.5 ppm) and $\mathrm{Nd}$ (16.9-51.1 ppm) are the most abundant LREEs, and Gd (2.4-10.4 ppm), Dy (2.4-14.1 ppm), Er (1.8-11.3 ppm) and $\mathrm{Yb}(2.3-16.1 \mathrm{ppm})$ are the most abundant HREEs. The LaN/YbN ratio is between 3.0 and 6.0. 
Caracterização Mineralógica, Geoquímica e Potencial Econômico de Ocorrências De Terras Raras do Maciço Granítico Serra do Mendes, Goiás.

Table 2. Whole-rock compositions for granites, saprolites and alluvial sediments from the SMGM

\begin{tabular}{|c|c|c|c|c|c|c|c|c|c|c|c|c|c|c|c|c|c|c|c|c|c|c|c|}
\hline \multicolumn{2}{|l|}{$\begin{array}{l}\text { Sample } \\
\text { No }\end{array}$} & $\begin{array}{l}\text { AZME- } \\
02 \mathrm{~A}\end{array}$ & $\begin{array}{l}\text { AZME- } \\
\text { 02B }\end{array}$ & $\begin{array}{l}\text { AZME- } \\
\text { 07D }\end{array}$ & $\begin{array}{l}\text { AZME- } \\
\text { 08A }\end{array}$ & $\begin{array}{l}\text { TF05- } \\
\text { I-164 }\end{array}$ & $\begin{array}{l}\text { ME } \\
\mathbf{0 3}\end{array}$ & $\begin{array}{l}\text { ME } \\
01 \mathrm{~A}\end{array}$ & ME 12 & $\begin{array}{l}\text { AZME- } \\
\text { 07A }\end{array}$ & $\begin{array}{l}\text { AZME- } \\
\text { 07B }\end{array}$ & $\begin{array}{l}\text { AZME- } \\
\text { 07C }\end{array}$ & $\begin{array}{l}\text { AZME- } \\
10 A\end{array}$ & $\begin{array}{l}\text { AZME- } \\
\text { 04C }\end{array}$ & ME08 & $\begin{array}{l}\text { AZME- } \\
05 \mathrm{~A}\end{array}$ & AZME05B & $\begin{array}{l}\text { AZME- } \\
\text { 13A }\end{array}$ & $\begin{array}{l}\text { AZME- } \\
\text { 05D }\end{array}$ & $\begin{array}{l}\text { AZME- } \\
12 \mathrm{~A}\end{array}$ & $\begin{array}{l}\text { AZME- } \\
12 B\end{array}$ & $\begin{array}{l}\text { AZME- } \\
\text { 14B }\end{array}$ & \begin{tabular}{|l|} 
TF05- \\
I- \\
171b \\
\end{tabular} \\
\hline \multicolumn{2}{|c|}{ Material type } & & & & & Rock & Rock & Rock & Rock & $\begin{array}{l}\text { Gray } \\
\text { saprolite }\end{array}$ & $\begin{array}{l}\text { saprolite } \\
\text { gray- } \\
\text { brown }\end{array}$ & $\begin{array}{l}\text { Gray- } \\
\text { red } \\
\text { Saprolite }\end{array}$ & $\begin{array}{l}\text { saprolit } \\
\text { yellow- } \\
\text { rad }\end{array}$ & & Rock & Saprolite & $\begin{array}{l}\text { clay- } \\
\text { saprolite }\end{array}$ & $\begin{array}{l}\text { soil- } \\
\text { saprolite }\end{array}$ & $\begin{array}{l}\text { clay- } \\
\text { sand, } \\
\text { creek }\end{array}$ & $\begin{array}{l}\text { sediments } \\
\text { creek }\end{array}$ & $\begin{array}{l}\text { sediments } \\
\text { creek }\end{array}$ & $\begin{array}{l}\text { sediments } \\
\text { creek }\end{array}$ & Rock \\
\hline \multicolumn{2}{|l|}{ Gr group } & PB1a & PB1a & PB1a & PB1a & PB1a & PB1a & PB1a & PB1a & PB1a & PB1a & PB1a & PB1a & PB1c & $\mathrm{PB} 1 \mathrm{c}$ & PB1c & $\mathrm{PB} 1 \mathrm{c}$ & PB 1c & PB1c & $\mathrm{PB} 1 \mathrm{c}$ & $\mathrm{PB} 1 \mathrm{c}$ & PB1a & PB $1 b$ \\
\hline $\mathrm{SiO} 2$ & (wt.\%) & 66.92 & 74.45 & 66.99 & 66.19 & 66.45 & 67.34 & 65.75 & 66.27 & 70.72 & 66.16 & 62.75 & 56.11 & 77.07 & 76.37 & 73.56 & 72.61 & 67.72 & 83.29 & 83.41 & 84.06 & 85.96 & 73.48 \\
\hline $\mathrm{TiO} 2$ & (wt.\%) & 0.78 & 0.26 & 0.76 & 0.83 & 0.89 & 0.76 & 0.82 & 0.77 & 0.02 & 0.91 & 0.91 & 1.06 & 0.07 & 0.04 & 0.08 & 0.13 & 0.83 & 0.08 & 1.40 & 0.80 & 2.21 & 0.22 \\
\hline $\mathrm{A} 12 \mathrm{O} 3$ & (wt.\%) & 13.93 & 12.16 & 14.17 & 14.16 & 13.84 & 13.78 & 13.19 & 14.01 & 17.54 & 14.41 & 16.08 & 16.23 & 11.99 & 12.25 & 14.98 & 15.41 & 15.21 & 7.79 & 6.95 & 7.02 & 4.60 & 13.66 \\
\hline $\mathrm{Fe} 2 \mathrm{O} 3$ & (wt.\%) & 6.30 & 2.63 & 6.71 & 7.10 & 7.56 & 6.11 & 6.34 & 5.17 & 0.32 & 7.40 & 8.13 & 13.63 & 1.47 & 1.13 & 1.71 & 2.44 & 5.18 & 1.65 & 2.27 & 2.00 & 2.57 & 2.41 \\
\hline $\mathrm{MnO}$ & (wt.\%) & 0.11 & 0.04 & 0.09 & 0.10 & 0.10 & 0.04 & 0.08 & 0.07 & $<0.01$ & 0.10 & 0.09 & 0.12 & 0.02 & 0.02 & 0.02 & 0.01 & 0.08 & $<0.01$ & 0.08 & 0.04 & 0.13 & 0.03 \\
\hline $\mathrm{MgO}$ & (wt.\%) & 0.63 & 0.12 & 0.54 & 0.59 & 0.61 & 0.74 & 0.73 & 0.82 & 0.02 & 0.74 & 0.59 & 0.60 & 0.01 & 0.02 & 0.02 & 0.07 & 0.48 & 0.04 & 0.08 & 0.09 & 0.08 & 0.16 \\
\hline $\mathrm{CaO}$ & (wt.\%) & 2.81 & 1.05 & 2.56 & 2.51 & 2.12 & 2.34 & 2.31 & 2.34 & 0.03 & 1.02 & 0.14 & 0.13 & 0.54 & 0.55 & 0.01 & 0.01 & 0.12 & 0.03 & 0.09 & 0.10 & 0.07 & 0.68 \\
\hline $\mathrm{Na} 2 \mathrm{O}$ & (wt.\%) & 3.70 & 2.64 & 2.66 & 2.62 & 2.20 & 2.98 & 3.01 & 2.60 & 2.67 & 1.60 & 0.49 & 0.26 & 2.67 & 3.18 & 0.12 & 0.09 & 0.24 & 0.37 & 0.70 & 0.70 & 0.33 & 2.95 \\
\hline $\mathrm{K} 2 \mathrm{O}$ & (wt.\%) & 3.52 & 5.51 & 4.35 & 4.68 & 4.73 & 4.42 & 4.37 & 4.67 & 4.74 & 4.81 & 4.67 & 3.87 & 4.94 & 4.59 & 4.74 & 2.61 & 3.34 & 2.44 & 3.52 & 3.50 & 2.19 & 5.71 \\
\hline $\mathrm{P} 2 \mathrm{O} 5$ & (wt.\%) & 0.27 & 0.04 & 0.26 & 0.29 & 0.33 & 0.36 & 0.37 & 0.32 & 0.02 & 0.26 & 0.09 & 0.26 & $<0.01$ & 0.02 & $<0.01$ & 0.01 & 0.07 & 0.01 & 0.05 & 0.05 & 0.05 & 0.15 \\
\hline P.F. & (wt.\%) & 0.70 & 0.80 & 0.60 & 0.60 & 0.90 & 1.36 & 1.45 & 0.92 & 3.90 & 2.20 & 5.70 & 7.30 & 1.00 & 0.92 & 4.60 & 6.40 & 6.40 & 4.20 & 1.20 & 1.50 & 1.50 & 0.50 \\
\hline TOTAL & (wt.\%) & 99.68 & 99.71 & 99.69 & 99.67 & 99.73 & 100.33 & 98.42 & 97.96 & 99.95 & 99.65 & 99.61 & 99.55 & 99.80 & 99.43 & 99.82 & 99.80 & 99.70 & 99.88 & 99.78 & 99.85 & 99.71 & 99.95 \\
\hline ASI & & 1.39 & 1.32 & 1.48 & 1.44 & 1.53 & 1.41 & 1.36 & 1.46 & 2.36 & 1.94 & 3.03 & 3.81 & 1.47 & 1.47 & 3.08 & 5.69 & 4.11 & 2.74 & 1.61 & 1.63 & 1.78 & 1.46 \\
\hline $\mathrm{Rb}$ & (ppm) & 167.50 & 255.70 & 200.10 & 268.00 & 226.50 & 202.00 & 194.00 & 223.50 & 580.30 & 373.70 & 252.30 & 217.40 & 757.30 & 695.90 & 671.50 & 307.10 & 189.20 & 270.80 & 169.00 & 170.50 & 68.80 & 467.50 \\
\hline $\mathrm{Sr}$ & $(\mathrm{ppm})$ & 467.30 & 168.90 & 143.60 & 206.90 & 135.00 & 129.00 & 145.00 & 135.00 & 16.40 & 86.40 & 66.60 & 94.70 & 11.40 & 11.70 & 1.00 & 4.80 & 48.50 & 5.70 & 27.40 & 28.40 & 19.00 & 36.10 \\
\hline $\mathrm{Zr}$ & (ppm) & 568.40 & 380.00 & 627.80 & 584.40 & 567.60 & 467.00 & 488.20 & 443.00 & 49.60 & 721.10 & 729.20 & 831.60 & 141.10 & 124.70 & 194.80 & 322.70 & 973.10 & 256.30 & 1020.30 & 554.80 & 1786.60 & 209.10 \\
\hline Cs & $(\mathrm{ppm})$ & 3.00 & 1.40 & 3.00 & 4.80 & 2.80 & 2.90 & $<5,00$ & $<5,00$ & 1.60 & 2.90 & 4.00 & 4.20 & 8.20 & $<5,00$ & 6.60 & 3.90 & 2.10 & 2.10 & 0.80 & 0.80 & 0.50 & 3.60 \\
\hline $\mathrm{Ba}$ & $(\mathrm{ppm})$ & 849.00 & 401.00 & 1002.00 & 1173.00 & 1073.30 & 889.00 & 902.00 & 796.10 & 177.00 & 1176.00 & 1205.00 & 1052.00 & 20.00 & 26.30 & 30.00 & 44.00 & 674.00 & 27.00 & 461.00 & 479.00 & 295.00 & 302.80 \\
\hline $\mathrm{Ga}$ & (ppm) & 22.30 & 23.60 & 24.20 & 23.50 & 25.20 & 18.50 & 18.70 & 19.10 & 76.00 & 26.50 & 27.90 & 28.10 & 39.00 & 34.20 & 42.20 & 45.50 & 21.00 & 21.80 & 10.80 & 10.60 & 5.00 & 25.70 \\
\hline V & (ppm) & 20.00 & $<8$ & 22.00 & 22.00 & 27.00 & n.a. & n.a. & n.a. & $<8$ & 23.00 & 34.00 & 47.00 & $<8$ & n.a. & $<8$ & 15.00 & 23.00 & 17.00 & 12.00 & 15.00 & 13.00 & 11.00 \\
\hline $\mathrm{Sn}$ & (ppm) & 3.00 & 13.00 & 6.00 & 9.00 & 4.00 & $<3,00$ & $<3,00$ & $<3,00$ & 8.00 & 9.00 & 8.00 & 4.00 & 9.00 & 17.90 & 17.00 & 18.00 & 4.00 & 8.00 & 6.00 & 4.00 & 3.00 & 9.00 \\
\hline W & $(\mathrm{ppm})$ & 1.20 & 1.90 & 1.90 & 2.40 & & & & & 5.30 & 5.70 & 2.80 & 1.10 & 13.60 & & 19.80 & 9.90 & 1.70 & 6.70 & 2.50 & 1.90 & 1.70 & \\
\hline $\mathrm{Ta}$ & $(\mathrm{ppm})$ & 1.70 & 2.60 & 1.90 & 1.90 & 2.50 & n.a. & $\begin{array}{r}1.60 \\
3\end{array}$ & n.a. & 65.80 & 2.30 & 2.80 & 2.40 & 9.80 & 6.60 & 10.40 & 10.10 & 2.10 & 8.70 & 3.90 & 2.50 & 3.80 & 7.00 \\
\hline $\mathrm{Nb}$ & $(\mathrm{ppm})$ & 29.50 & 31.80 & 29.30 & 31.80 & 33.60 & 30.40 & 0.60 & 30.30 & 81.90 & 34.00 & 32.10 & 37.70 & 101.70 & 69.10 & 105.50 & 100.70 & 30.40 & 87.20 & 50.90 & 32.10 & 58.40 & 62.80 \\
\hline $\mathrm{Hf}$ & $(\mathrm{ppm})$ & 14.00 & 13.50 & 15.70 & 14.40 & 16.20 & n.a. & 15.00 & n.a. & 8.90 & 18.50 & 18.20 & 21.00 & 8.20 & 8.60 & 11.30 & 16.40 & 26.30 & 11.60 & 26.60 & 14.60 & 45.70 & 7.70 \\
\hline
\end{tabular}


Caracterização Mineralógica, Geoquímica e Potencial Econômico de Ocorrências De Terras Raras do Maciço Granítico Serra do Mendes, Goiás.

\begin{tabular}{|c|c|c|c|c|c|c|c|c|c|c|c|c|c|c|c|c|c|c|c|c|c|c|c|}
\hline \multicolumn{2}{|c|}{$\begin{array}{l}\text { Sample } \\
\text { No }\end{array}$} & \multirow{2}{*}{\begin{tabular}{|l}
$\begin{array}{l}\text { AZME- } \\
\text { 02A }\end{array}$ \\
14.00
\end{tabular}} & \multirow{2}{*}{$\begin{array}{r}\begin{array}{l}\text { AZME- } \\
\text { 02B }\end{array} \\
17.00\end{array}$} & \multirow{2}{*}{$\begin{array}{r}\begin{array}{l}\text { AZME- } \\
\text { 07D }\end{array} \\
15.00\end{array}$} & \multirow{2}{*}{$\frac{\begin{array}{l}\text { AZME- } \\
\mathbf{0 8 A}\end{array}}{15.00}$} & \multirow{2}{*}{$\begin{array}{r}\begin{array}{c}\text { TF05- } \\
\text { I-164 }\end{array} \\
17.00\end{array}$} & \multirow{2}{*}{$\begin{array}{l}\text { ME } \\
\mathbf{0 3} \\
14.10\end{array}$} & \multirow{2}{*}{$\begin{array}{c}\text { ME } \\
\mathbf{0 1 A}\end{array}$} & \multirow{2}{*}{\begin{tabular}{r|} 
ME 12 \\
10.60
\end{tabular}} & \multirow{2}{*}{\begin{tabular}{r|}
$\begin{array}{l}\text { AZME- } \\
\text { 07A }\end{array}$ \\
13.00
\end{tabular}} & \multirow{2}{*}{$\begin{array}{r}\begin{array}{l}\text { AZME- } \\
\text { 07B }\end{array} \\
16.00\end{array}$} & \multirow{2}{*}{$\begin{aligned} \begin{array}{l}\text { AZME- } \\
\text { 07C }\end{array} \\
18.00\end{aligned}$} & \multirow{2}{*}{\begin{tabular}{|c|}
$\begin{array}{l}\text { AZME- } \\
\text { 10A }\end{array}$ \\
21.00
\end{tabular}} & \multirow{2}{*}{$\frac{\begin{array}{l}\text { AZME- } \\
\mathbf{0 4 C}\end{array}}{7.00}$} & \multirow{2}{*}{$\begin{array}{r}\text { ME08 } \\
5.58\end{array}$} & \multirow{2}{*}{\begin{tabular}{|r|}
$\begin{array}{l}\text { AZME- } \\
\text { 05A }\end{array}$ \\
9.00
\end{tabular}} & \multirow{2}{*}{\multicolumn{2}{|c|}{$\begin{array}{rl}\text { AZME05B } & \begin{array}{l}\text { AZME- } \\
\text { 13A }\end{array} \\
10.00 & 10.00\end{array}$}} & \multirow{2}{*}{\begin{tabular}{|r}
$\begin{array}{l}\text { AZME- } \\
\text { 05D }\end{array}$ \\
5.00
\end{tabular}} & \multirow{2}{*}{$\begin{array}{l}\frac{\text { AZME- }_{\text {12A }}}{4.00} \\
\end{array}$} & \multirow{2}{*}{$\begin{array}{l}\frac{l_{\text {AZME- }}^{\text {12B }}}{3.00} \\
\end{array}$} & \multirow{2}{*}{$\begin{array}{r}\begin{array}{l}\text { AZME- } \\
\text { 14B }\end{array} \\
3.00\end{array}$} & \multirow{2}{*}{ 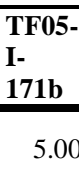 } \\
\hline Sc & (ppm) & & & & & & & & & & & & & & & & & & & & & & \\
\hline $\mathrm{Tl}$ & (ppm) & 0.70 & 0.80 & 0.80 & 1.20 & & & & & $<0.1$ & 1.30 & 1.10 & 1.00 & 0.60 & & 0.30 & 0.40 & 0.50 & 0.20 & 0.10 & 0.10 & $<0.1$ & \\
\hline $\mathrm{Zn}$ & (ppm) & 144.00 & 167.00 & 116.00 & 144.00 & 110.00 & 67.00 & 93.70 & 71.40 & 4.00 & 80.00 & 130.00 & 109.00 & 21.00 & 61.50 & 5.00 & 12.00 & 28.00 & 9.00 & 18.00 & 17.00 & 11.00 & 43.00 \\
\hline Mo & (ppm) & 0.50 & 1.90 & 0.70 & 0.70 & 1.00 & n.a. & n.a. & n.a. & $<0.1$ & 0.50 & 0.80 & 1.70 & 2.10 & n.a. & 0.10 & 0.60 & 0.60 & 0.70 & 0.20 & 0.20 & 0.20 & 0.90 \\
\hline $\mathrm{Pb}$ & (ppm) & 16.20 & 63.80 & 31.20 & 17.90 & 23.40 & 28.60 & 21.30 & 23.70 & 7.30 & 20.10 & 28.80 & 28.90 & 27.70 & 70.30 & 27.80 & 43.40 & 17.90 & 28.10 & 11.90 & 12.20 & 5.70 & 25.70 \\
\hline Th & (ppm) & 25.40 & 112.10 & 25.50 & 23.30 & 33.80 & 35.80 & 27.10 & 34.60 & 17.20 & 34.10 & 36.60 & 40.60 & 76.20 & 55.90 & 78.80 & 104.20 & 40.90 & 49.10 & 22.50 & 17.60 & 12.00 & 55.00 \\
\hline $\mathrm{U}$ & (ppm) & 3.90 & 14.30 & 4.10 & 4.10 & 5.40 & 8.00 & 4.30 & $<3,00$ & 4.00 & 4.60 & 6.10 & 8.80 & 20.20 & 19.80 & 16.50 & 21.30 & 6.90 & 13.60 & 5.60 & 5.00 & 4.40 & 12.10 \\
\hline Y & (ppm) & 59.10 & 136.00 & 73.30 & 56.20 & 185.90 & 58.40 & 58.50 & 64.20 & 10.30 & 139.40 & 99.40 & 57.80 & 291.30 & 305.40 & 92.40 & 180.50 & 42.30 & 79.60 & 19.80 & 16.30 & 14.60 & 62.80 \\
\hline $\mathrm{La}$ & (ppm) & 100.30 & 206.00 & 110.50 & 85.70 & 199.00 & 74.00 & 81.60 & 82.10 & 10.00 & 84.50 & 142.50 & 160.20 & 200.70 & 92.80 & 273.70 & 127.30 & 80.80 & 72.30 & 31.70 & 26.10 & 19.30 & 71.20 \\
\hline $\mathrm{Ce}$ & (ppm) & 181.00 & 440.40 & 195.30 & 177.90 & 210.80 & 167.00 & 153.00 & 158.00 & 23.80 & 170.60 & 330.50 & 889.20 & 334.20 & 151.00 & 316.10 & 403.70 & 284.90 & 269.50 & 57.50 & 50.90 & 39.80 & 155.10 \\
\hline $\operatorname{Pr}$ & (ppm) & 22.89 & 46.99 & 27.69 & 21.34 & 46.72 & 19.52 & 17.16 & 17.74 & 3.20 & 22.66 & 38.80 & 34.72 & 41.26 & 18.74 & 50.52 & 25.74 & 18.62 & 15.21 & 7.07 & 5.63 & 4.58 & 17.17 \\
\hline $\mathrm{Nd}$ & $(\mathrm{ppm})$ & 86.70 & 167.50 & 106.60 & 82.10 & 187.60 & 64.90 & 63.60 & 66.40 & 12.00 & 92.30 & 152.00 & 126.00 & 147.40 & 63.60 & 166.30 & 87.20 & 67.10 & 51.10 & 23.80 & 19.70 & 16.90 & 62.70 \\
\hline $\mathrm{Sm}$ & (ppm) & 16.02 & 30.23 & 19.08 & 15.20 & 33.60 & 15.00 & 10.40 & 11.00 & 2.40 & 18.67 & 28.11 & 20.41 & 37.47 & 13.00 & 26.64 & 18.28 & 11.70 & 10.93 & 4.60 & 3.67 & 3.11 & 12.60 \\
\hline $\mathrm{Eu}$ & (ppm) & 1.85 & 0.59 & 2.13 & 1.91 & 3.58 & 1.63 & 1.62 & 1.39 & 0.28 & 2.27 & 3.35 & 2.17 & 0.42 & 0.10 & 0.28 & 0.25 & 0.93 & 0.14 & 0.46 & 0.36 & 0.23 & 0.28 \\
\hline $\mathrm{Gd}$ & (ppm) & 13.38 & 25.22 & 16.72 & 13.47 & 34.56 & 8.05 & 11.60 & 13.08 & 2.10 & 19.29 & 23.49 & 18.71 & 40.30 & 21.28 & 17.29 & 18.57 & 10.12 & 10.48 & 3.68 & 3.02 & 2.49 & 10.19 \\
\hline $\mathrm{Tb}$ & (ppm) & 1.96 & 4.22 & 2.59 & 1.98 & 5.56 & 1.32 & 1.53 & 1.70 & 0.36 & 3.17 & 3.55 & 2.46 & 8.23 & 4.09 & 2.40 & 3.92 & 1.47 & 2.06 & 0.64 & 0.55 & 0.39 & 2.01 \\
\hline Dy & (ppm) & 10.63 & 24.72 & 13.92 & 11.37 & 29.59 & 9.25 & 9.84 & 10.80 & 2.10 & 19.13 & 19.41 & 13.27 & 51.03 & 30.50 & 14.07 & 27.23 & 8.24 & 14.15 & 3.78 & 3.23 & 2.45 & 9.95 \\
\hline Ho & (ppm) & 2.12 & 5.12 & 2.67 & 2.23 & 6.61 & 2.10 & 1.96 & 2.13 & 0.41 & 4.41 & 3.88 & 2.34 & 11.19 & 7.62 & 3.27 & 6.54 & 1.54 & 3.24 & 0.82 & 0.71 & 0.55 & 2.32 \\
\hline Er & (ppm) & 6.44 & 15.66 & 8.01 & 6.23 & 17.73 & 6.40 & 5.72 & 6.19 & 1.31 & 12.93 & 10.59 & 6.56 & 35.23 & 23.95 & 11.45 & 23.76 & 4.64 & 11.63 & 2.77 & 2.40 & 1.87 & 6.79 \\
\hline $\mathrm{Tm}$ & $(\mathrm{ppm})$ & 0.84 & 2.29 & 1.13 & 0.88 & 2.56 & 1.02 & 0.83 & 0.89 & 0.20 & 1.84 & 1.56 & 0.95 & 5.83 & 4.05 & 2.04 & 4.27 & 0.68 & 2.14 & 0.47 & 0.41 & 0.31 & 0.85 \\
\hline $\mathrm{Yb}$ & (ppm) & 5.41 & 14.89 & 7.06 & 5.59 & 13.62 & 6.89 & 4.96 & 5.26 & 1.67 & 11.22 & 9.58 & 6.08 & 39.77 & 30.20 & 15.63 & 31.57 & 4.41 & 16.18 & 3.54 & 3.12 & 2.37 & 5.50 \\
\hline $\mathrm{Lu}$ & (ppm) & 0.80 & 2.15 & 1.04 & 0.83 & 2.29 & n.a. & n.a. & n.a. & 0.25 & 1.73 & 1.41 & 0.89 & 5.66 & n.a. & 2.44 & 4.97 & 0.64 & 2.54 & 0.56 & 0.46 & 0.43 & 0.88 \\
\hline LREE & (ppm) & 408.76 & 891.71 & 461.30 & 384.15 & 681.30 & 342.05 & 327.38 & 336.63 & 51.68 & 391.00 & 695.26 & 1232.70 & 761.45 & 339.24 & 833.54 & 662.47 & 464.05 & 419.18 & 125.13 & 106.36 & 83.92 & 319.05 \\
\hline HREE & $(\mathrm{ppm})$ & 41.58 & 94.27 & 53.14 & 42.58 & 112.52 & 35.03 & 36.46 & 40.05 & 8.40 & 73.72 & 73.47 & 51.26 & 197.24 & 121.69 & 68.59 & 120.83 & 31.74 & 62.42 & 16.26 & 13.90 & 10.86 & 38.49 \\
\hline REE & (ppm) & 450.34 & 985.98 & 514.44 & 426.73 & 793.82 & 377.08 & 363.84 & 376.68 & 60.08 & 464.72 & 768.73 & 1283.96 & 958.69 & 460.93 & 902.13 & 783.30 & 495.79 & 481.60 & 141.39 & 120.26 & 94.78 & 357.54 \\
\hline $\mathrm{LaN} / \mathrm{Yl}$ & & 12.50 & 9.33 & 10.55 & 10.34 & 9.85 & 7.24 & 11.09 & 10.52 & 4.04 & 5.08 & 10.03 & 17.76 & 3.40 & 2.07 & 11.81 & 2.72 & 12.35 & 3.01 & 6.04 & 5.64 & 5.49 & 8.73 \\
\hline $\mathrm{Rb} / \mathrm{Sr}$ & & 0.36 & 1.51 & 1.39 & 1.30 & 1.68 & 1.57 & 1.34 & 1.66 & 35.38 & 4.33 & 3.79 & 2.30 & 66.43 & 59.48 & 671.50 & 63.98 & 3.90 & 47.51 & 6.17 & 6.00 & 3.62 & 12.95 \\
\hline
\end{tabular}


Figures $15 \mathrm{a}$ and $15 \mathrm{~b}$ show that the rocks and saprolites belonging to the facies PB1c, the most highly developed facies and therefore the richest in $\mathrm{SiO}_{2}$, contain $\mathrm{REE}+\mathrm{Y}$ at concentrations in excess of $1000 \mathrm{ppm}$. There is greater dispersion among the saprolites belonging to the less evolved facies, PB1a, than in the parental granite. The REE concentrations in the alluvial sediment samples are relatively low, which may be associated with the high concentration of quartz and consequent dilution of REEs in the selected samples.

Figure $15 \mathrm{c}$ shows the $\mathrm{LaN} / \mathrm{YbN}$ ratio vs. $\mathrm{SiO}_{2}$ (wt.\%). The rocks and saprolites belonging to the most developed facies, PB1c, display lower $\mathrm{LaNd} / \mathrm{YbN}$ ratios than facies PB1a. This difference indicates that the amount (wt.\%) of $\mathrm{SiO}_{2}$ in the samples is directly proportional to the amount of associated HREE+Y: facies PB1a is richest in LREEs, and the most developed facies, PB1c, is richest in HREE.

The REE diagrams normalized to the chondrite of Sun and McDonough (1989)) of the rocks and saprolites of facies PB1a are generally enriched in LREEs by a factor of more than 100, and the saprolites are more enriched than their parent rocks (Figure 15d). The HREE, similarly, are more abundant in the saprolites than in the parent rock, although these concentrations are below 100 ppm (decreasing diagram).

The most developed facies, PB1c, displays enrichment in LREEs by a factor of up to 1000 versus the chondrite, a strong Eu anomaly and an ascending (seagull type) plot of the HREEs, both for the rock and saprolite samples, although the latter do not all contain concentrations greater than those in their parent rock. Figure $15 f$ shows the REE diagram for the alluvial sediments, normalized to the chondrite. These REE concentrations reflect those of the source rock, which, according to the pattern, is very similar to that of the leucomonzogranite (facies PB1c).

To characterize the increase in REE concentrations in facies PB1c, normalization of REEs was performed on the poorly evolved sample belonging to facies PB1a (sample AZME-07D). Enrichment in REE, particularly HREE, by a factor of up to 5 , is observed. The enrichment in LREE is not significant. (Figure 15g) 
a)

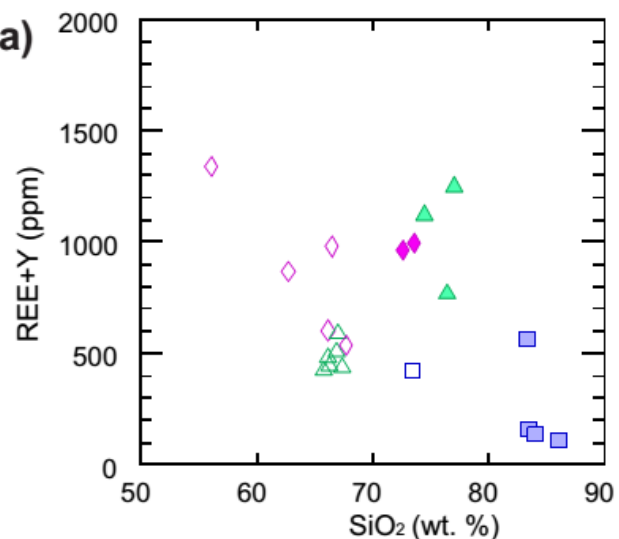

b)

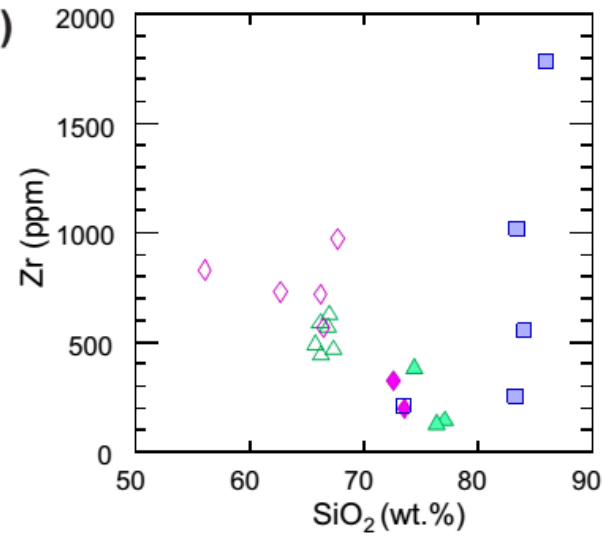

d) Biotite mozogranite and saprolite (PB1a)
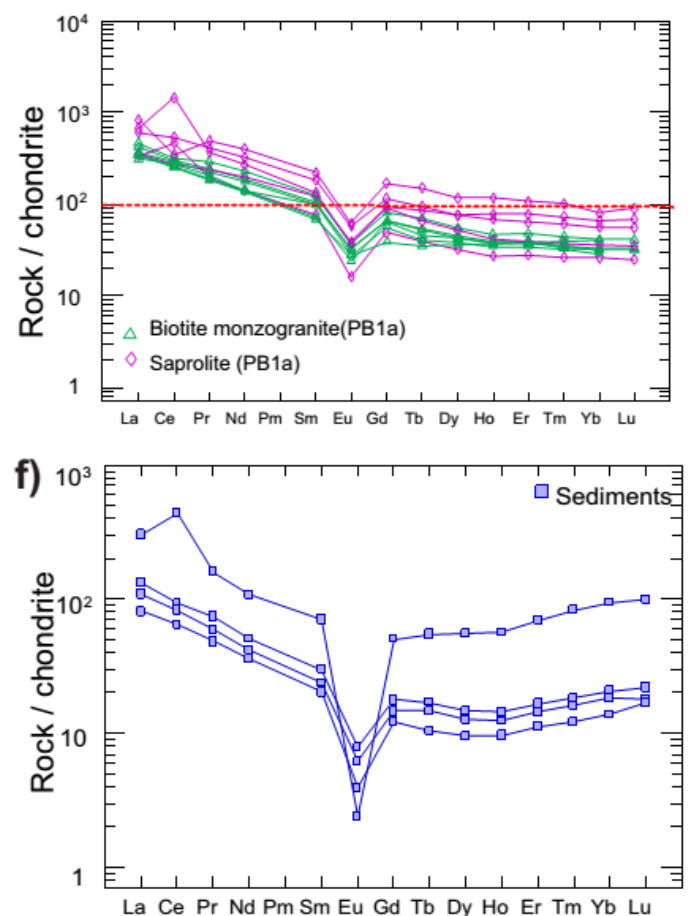

$\triangle$ Biotite monzogranite(PB1a)

$\square$ Biot.-fluorite granite(PB1b)

$\triangle$ Leucomonzogranite(PB1c)

$\checkmark$ Saprolite (PB1a)

$\checkmark$ Saprolite (PB1c)

$\square$ Sediments

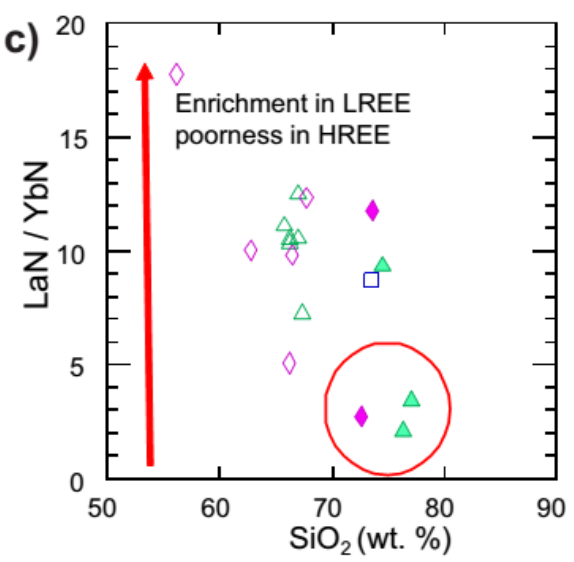

e) Leucomonzogranite and saprolite (PB1c)
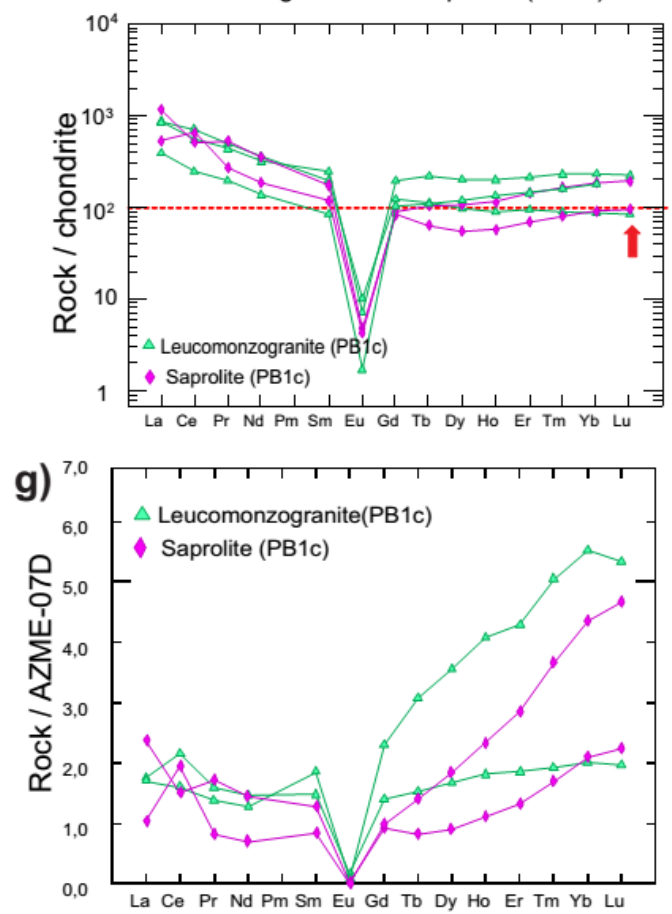

Figure 15. a) to c)Diagrams of $\mathrm{REE}+Y$ contents, $\mathrm{Zr}$ contents, and $\mathrm{LaN} / \mathrm{YbN}$ ratios vs. $\mathrm{SiO}_{2}$ contents showing an increasing in the REE, mainly in the HREE, contents with the increasing in $\mathrm{SiO}_{2}$ ); d) to f) chondrite-normalized REE patterns of the granites, saprolites and alluvial sediments; normalization values

from Sun \&McDonough (1989); g) REE patterns of the leucomonzogranite and associated saprolite normalized to the less evolved biotite granite (sample AZMEO7D), highlighting the enrichment in the HREE by a factor up to 5 
The interpolation of the REE $+Y$ data for the SMGM, even considering the low representativity of the sample, indicates that the REE richest area is located in the leucomonzogranite-PB1C and in the areas of the biotite granite nearby the contact between both facies This is indicated by the red area in the figure 16, with REE $+Y$ concentrations of 700-900 ppm.

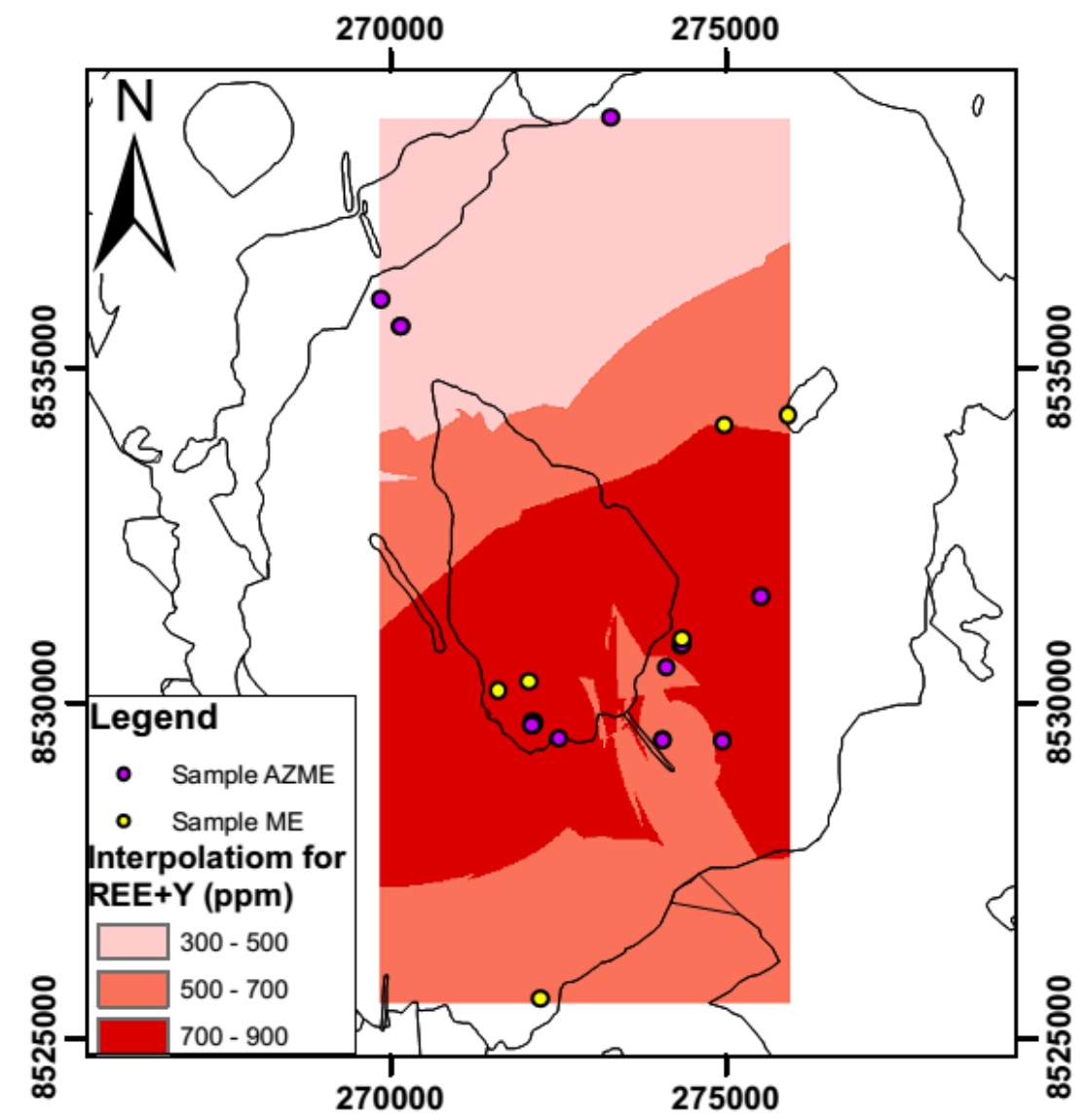

Figure 16. Map of geochemical anomalies for REE $+Y(p p m)$ in the SMGM.

\subsection{DISCUSSION}

The REE-bearing secondary minerals in the Serra do Mendes massif are fluocerite, bastnaesite and oxyfluoride and are products of hydrotermalism. The fluocerite has a low $\mathrm{F}$ content (11.9-16.7\% wt.), whereas the fluocerite-Ce content with normal concentrations of $F$ is approximately $28 \%$. This difference may be due to a destabilization of the system and phase transformation of minerals of the oxyfluorides and bastnaesite. According to Styles and Yong (1983), fluocerites can undergo 2 main types of alteration to bastnaesite-(La) and bastnaesite, where both transformations are controlled by the presence of monazite on the edges, based on an imbalance with minerals of the oxides group. The strong fractionation between LREEs and 
HREEs is mainly due to structural constraints. Structural studies by Staritzky and Asprey (1957) indicated that $\mathrm{LaF}_{3}$ and $\mathrm{NdF}_{3}$ crystallize in the hexagonal system, whereas $\mathrm{SmF}_{3}$ and $\mathrm{YbF}_{3}$ crystallize in the orthorhombic system. Thus, the structure of the fluocerite is highly selective for LREEs, and incorporation of HREEs occurs only in small concentrations.

Decomposition textures were observed in the oxyfluorides present mainly in facies PB1c, by Teixeira (2002) in oxyfluorides belonging to the Pedra Branca Suite and by Johan and Johan (1994) in oxyfluorides of the Cínovec dome granite (Czech Republic), where 3 phases were observed: one rich in $\mathrm{La}$, one rich in $\mathrm{Ce}$ and one intermediate phase. These three phases may be due to the destabilization of the system with time and/or a decrease in temperature, which excluded the 3 phases.

Assuming that the bastnaesites in this study are secondary minerals formed by decomposition of the allanite, the most advanced facies of the Serra do Mendes granite massif (Leucomonzogranite-PB1c) may have been acted on by some type of hydrothermal effect. Substitution of bastnaesite for allanite is commonly described in the literature; more rarely, bastnaesite can form from monazite and fluocerite (Littlejohn 1981, Kamineni and Bonardi 1983, Styles and Young 1983, Williams-Jones and Wood 1992, Forster 2000). According to Littlejohn (1981), the decomposition of allanite and formation of bastnaesite are described by equations (5) and (6); thorite may or may not form, depending on the availability of Th within the structure of the allanite. The formation of bastnaesite from fluocerite is described by equation (7) (Slyles and Young 1983), and its formation from monazite proceeds in accordance with equation (8) (Watson and Synman 1975).

$(\mathrm{Ca}, \mathrm{REE})_{2}\left(\mathrm{Al}_{2}, \mathrm{Fe}\right)_{3} \mathrm{Si}_{3} \mathrm{O}_{12}(\mathrm{OH})+\mathrm{F}, \mathrm{CO}_{2} \rightleftharpoons \mathrm{REEFCO}{ }_{3}+\mathrm{CaF}_{2}+\mathrm{Al}_{4} \mathrm{Si}_{4} \mathrm{O}_{10}(\mathrm{OH})_{8}+\mathrm{Fe}_{3} \mathrm{O}_{4}$

$$
\text { Allanite bastnaesite fluorite }
$$

$(\mathrm{Ce}, \mathrm{Ca}, \mathrm{Th})_{2}(\mathrm{Al}, \mathrm{Fe})_{3} \mathrm{Si}_{3} \mathrm{O}_{12}(\mathrm{OH})+\mathrm{F}, \mathrm{CO}_{2} \mathrm{H}_{2} \rightleftharpoons \mathrm{ThSiO}_{4}+\mathrm{CeFCO}{ }_{3}+3 \mathrm{SiO}_{2} \cdot(\mathrm{Al}, \mathrm{Fe})_{2} \mathrm{O}_{3} . \mathrm{nH} 2 \mathrm{O}+\mathrm{Ca}^{+2}$

Allanite fluid thorite bastnaesite montmorillonite

$\mathrm{Ce}_{2} \mathrm{La}_{1,5}(\mathrm{Nb}, \mathrm{Pr}, \mathrm{Th})_{0,5} \mathrm{~F}_{12}+\mathrm{CO}_{2}$ rich fluid $\rightleftharpoons \mathrm{Ce} 2 \mathrm{La}_{1,5}(\mathrm{Nb}, \mathrm{Pr})_{0,5}\left(\mathrm{CO}_{3}\right)_{4} \mathrm{~F}_{4+}$ Th rich phase +

Fluocerite bastnaesite

F rich fluid (7)

$\mathrm{REEPO} \mathrm{O}_{4}+\mathrm{HF}_{\mathrm{aq}}^{\circ}+\mathrm{H}_{2} \mathrm{O}+\mathrm{CO}_{2 a q} \rightleftharpoons \mathrm{REE}\left(\mathrm{CO}_{3}\right) \mathrm{F}+\mathrm{H}_{2} \mathrm{OPO}_{4 a q}$ (8)

Monazite bastnaesite

In all cases, these reactions involve the action of a hydrothermal fluid rich in $\mathrm{F}$ and $\mathrm{C}$, as mentioned in previous studies of the Granitic Massifs Pedra Branca. These studies discussed a 
fluid rich in volatiles, mainly F, as the cause of the hydrothermalism (Botelho and Moura 1998, Freitas 2000, Lenharo et al., 2002, Teixeira and Botelho 2001, Teixeira and Botelho 2006, Moura et al., 2014).

The study by Wood and Ricketts (2000) described the response of allanite to hydrothermal alteration. The decomposition of allanite and removal of REE and Th are facilitated by the formation of fluoride complexes. The decomposition of allanite is a 2-stage process represented by equation (9).

$\mathrm{CeCaFeAl} 2 \mathrm{Si}_{3} \mathrm{O}_{12} \mathrm{OH}+2 \mathrm{~F}^{-}+5 \mathrm{H}^{+}+5 \mathrm{H}_{2} \mathrm{O}_{a q}+\mathrm{H}_{2} \mathrm{PO}_{4}-\mathrm{CaF}_{2}+\mathrm{CePO} 4+\mathrm{Fe}^{2+}+3 \mathrm{H}_{4} \mathrm{SiO}_{4}{ }^{\circ}+2 \mathrm{Al}(\mathrm{OH})_{3}^{\circ}$ (9)

\section{Allanite}

fluorite monazite

The allanite + epidote + bastnaesita \pm fluorite and argillomineral association is similar to that observed by Mineyev (1973). Epidote and fluorite represent the regions of the allanite from which the REEs were leached, probably as complexes with $F$, and the minerals of the bastnaesite group represent the regions where the REEs were fixed. A similar process was observed by Wood and Ricketts (2000), who reported the leaching of REEs from portions of allanite grains and their substitution by fluorite; the REEs were concentrated as monazite. For this process to occur, there must be destabilization in the structure of the allanite.

Thorite is present as a primary mineral or as a product of the decomposition of a variety of minerals, including allanite (Buda and Nagy, 1995), zircon (Pointer et al., 1988a; Rubin et al., 1989), monazite (Finger et al., 1998) and bastnaesite (Gieré et al., 1998). According to Speer (1982), thorite is one of the most complex minerals and can contain more than 40 elements in concentrations detectable using an EPMA; these elements may have various oxidation states. Thorite is usually present in its metamictic state.

According to Speer (1982), more than 50 elements can enter the mineral structure of zircon, the most common elements being $\mathrm{Y}, \mathrm{U}, \mathrm{Th}, \mathrm{REE}, \mathrm{Pb}, \mathrm{Ca}, \mathrm{Fe}, \mathrm{Na}, \mathrm{Ca}, \mathrm{Ti}, \mathrm{Nb}, \mathrm{Ta}, \mathrm{Al}$ and $\mathrm{P}$. Substitutions (10), (11) and (12) are the main substitution reactions observed in the zircons of facies PB1c.

$$
\begin{aligned}
& H f^{4+}{ }_{(A)} \rightleftharpoons Z r^{4+}{ }_{(A)}(\text { zircón - hafnon SS) (10) } \\
& \left(Y^{3+} R E^{3+}\right)_{(A)+}{ }^{P^{5+}{ }_{(B)}} \rightleftharpoons \mathrm{Zr}^{4+}{ }_{(A)}+S^{4{ }^{4}}{ }_{(B)}(\text { zircon - xenotime SS) (11) } \\
& \mathrm{Th}^{4+}{ }_{(\mathrm{A})} \rightleftharpoons \mathrm{Zr}^{4+}{ }_{(\mathrm{A})}(\text { zircon - thorite SS) }(12)
\end{aligned}
$$

According to Teixeira (2002), the zircons belonging to facies PB1 acquired their metamictic characteristics during the magmatic evolution, and the most evolved facies contain higher 
concentrations of Th, $\mathrm{U}, \mathrm{REE}$ and $\mathrm{P}$, which was verified in this study. A feature also commonly observed in metamictic zircons is the presence of water in its structure (Aines and Rossman 1986, Woodhead et al., 1991). This water could explains the concentration totals of less than $100 \%$ resulting from our analyses, which are between 82.2 and $97.7 \%$.

In the minerals belonging to the apatite group, $\mathrm{Ca}$ can be substituted for by $\mathrm{Na}, \mathrm{K}, \mathrm{Ag}, \mathrm{Sr}$, $\mathrm{Mg}, \mathrm{Zn}, \mathrm{Cd}, \mathrm{Sc}, \mathrm{Y}, \mathrm{REEs}, \mathrm{Bi}, \mathrm{U}$ or Th, whereas $\mathrm{PO}_{4}$ can be substituted for mainly by $\mathrm{SiO}_{4}, \mathrm{SO}_{4}$ and $\mathrm{CO}_{3}$. The principal substitution reactions acting on the apatite are represented by equations (13) and (14).

$$
\begin{aligned}
& \mathrm{Na}^{+}+\mathrm{REE}^{3+} \rightleftharpoons 2 \mathrm{Ca}^{2+} \text { (13) } \\
& \mathrm{REE}^{3+}+\mathrm{Si}^{4+} \rightleftharpoons \mathrm{Ca}^{2+}+P^{5+} \text { apatite and britholite SS (14) }
\end{aligned}
$$

According to Ito (1968), equation 14 occurs in high-temperature hydrothermal conditions, and its occurrence was reported earlier based on BSE images and analysis of apatites from greisenized granite of the Pedra Branca Suite (Botelho, 1992). According to Ronsbo (1989), the presence or lack of substitution (14) is controlled by the silica content of the rock. In rocks undersaturated in silica, equation (13) dominates, whereas in rocks closer to saturation, equation (14) dominates.

Geochemical data presented by Bao and Zhao (2008), who analyzed granitic rocks and their weathering profiles in 4 relevant granites in southern China, indicate that the Xinxiu muscovite granite contains REE at concentrations of $342.0 \mathrm{ppm}$ in the rock and values ranging from 277.1 to $1227.9 \mathrm{ppm}$ in the weathering profiles. These concentrations in the Guposhan biotite granite are $280.3 \mathrm{ppm}$ in the rock and 669.3-1324.1 ppm in the weathering profile; in the biotite granite of Hushan, 325.72 ppm in the rock and 429.4-679.3 ppm in its weathering profile; and in the porphyritic granite of Heling, $807.69 \mathrm{ppm}$ in the rock and 1212.79 to $3796 \mathrm{ppm}$ in its weathering profile.

Altered granitic rocks in the Nusab El Bagum area, in the southwestern desert of Egypt, were analyzed by Ibrahim et al. (2015). These local silicified and kaolinized granites contain REE at concentrations of 134-39133 and 34-752 ppm, respectively. These rocks, which are exposed across an area measuring $40 \mathrm{~m}^{2}$, were subjected to strong hydrothermal alteration that led to extreme enrichment in rare metals such as $\mathrm{Zr}, \mathrm{Nb}, \mathrm{Y}$ and $\mathrm{REE}$.

The weathering profiles developed on the Kata Beach granite in Phuket, Thailand (the underlying granite contains REEs at 592 ppm), contain low REE concentrations of 174-548 ppm in the upper part of the profile and higher REE concentrations of 578-1084 ppm in the lower part of the profile (depths of 4.5-12 m). This fractionation between LREE and HREE is controlled by 
the REE-bearing minerals and the absorption of the alteration products in the weathered granites (Sanematzu et al., 2013, Bao and Zhao, 2008; Ibrahim, 2015).

The geochemical results of the two granite facies belonging to the SMGM can be compared with the data presented by Bao and Zhao (2008) in the granitic province of southern China and with the Kate Beach granite data from Phuket (Sanematzu et al., 2013). The results presented by Ibrahim et al. (2015) indicate higher quantities only in a silicified granite, which is attributed to the strong hydrothermal processes that acted in the granitic area, which further favored the accumulation of these elements. All authors attributed the mobilization of REE mainly to the destabilization of REE-bearing accessory or alteration minerals, due to percolation of acidic meteoric waters. This percolation can cause marked chemical weathering, destabilization of minerals, and REE migration as aqueous solutions that can precipitate REE in the lower parts of weathering profiles and form part of the crystalline structure of neoformed clay minerals as a product of alteration.

\subsection{CONCLUSIONS}

The REE-bearing minerals in the SMGM, listed in order of REE concentrations, are fluocerite-Ce, bastnaesite, REE oxyfluorides, monazite, allanite, solid solutions of thorite, zircon, and apatite.

The most abundant REE-bearing minerals in facies PB1c are bastnaesite, monazite and thorite SS, with maximum amounts of REE (wt.\%) of 78.2, 53.8 and 62.1, respectively. The most abundant PB1a granite facies contains significant concentrations of monazite, thorite SS, zircon and apatite

Fluocerite and REE oxyfluorides, with REE concentrations (wt.\%) of up to 80.4 and 76.2, respectively, are present in smaller quantities and are restricted to granite facies PB1c.

Allanite, a common mineral in the 2 granite facies that can contain up to $29.3 \% \mathrm{REE}$, is prone to destabilization and alteration, and in contact with fluids rich in $\mathrm{F}$ and $\mathrm{CO}_{2}$, it can form bastnaesite.

The most developed facies of the SMGM (leucomonzogranite, PB1c) exhibits greater enrichment in REE, with a slight increase in REE $+Y$ concentrations, which is directly proportional to the $\mathrm{SiO}_{2}$ content. The $\mathrm{LaN} / \mathrm{YbN}$ ratio also confirms that $\mathrm{PB} 1 \mathrm{c}$, is more enriched in $R E E+Y$ than PB1a.

Based on the abundance of REE-bearing minerals such as oxyfluorides, fluocerite, bastnaesites and allanite within the biotite monzogranite (PB1a) and leucomonzogranite (PB1c) 
belonging to the SMGM, their weak resistance to weathering, their alteration products rich in REE, and their wide spatial distribution, it can be concluded that the region is suitable for the prospecting and exploration for REE.

Low rates of climatic and environmental denudation in the area underlain by the SMGM, in addition to granitic rocks and similar REE concentrations in rocks and their alteration products, make the SMGM comparable to the REE prospects of southern China, Thailand and Serra Dourada in Brazil.

\subsection{REFERENCES}

Aines, R.D. and Rossman, G.R.1986. Relatioships between radiation damage and trace wáter in zircón, topaz and quartz. Am. Mineral. 71,1183-1193

Alvarenga, C.J.S.; Dardenne, M.A.; Botelho, N.F.; Machado, M.A.; Lima, O.N.B.; Almeida, T. 2007. Relatório final das folhas Monte Alegre de Goiás, Cavalcante e Nova Roma. Programa Geologia do Brasil (PGB/CGB). UnB/CPRM.

Bgs, C., 2011. Rare Earth Elements. British Geological Survey.53 p.

Botelho, N. F. 1992. Les ensembles granitiques sublcalins a peralumineux mineralisés em Sn et In de la Sous-province Paranã. Etat de Goiás, Brésil. Université de Paris VI. Thèse de Doctorat. $344 \mathrm{p}$.

Botelho, N.F. and Moura M. 1998. Granite-ore deposit relationships in Central Brazil. Journal of South American Earth Sciences, 11 (5), 427-438.

Buda, G., Nagy, G. 1995. Some REE-bearing accessory mineralsin two types of Variscan granitoids, Hungary. Geologica Carphatica 46, 67-78.

Chi, R. and Tian, J. (2009) WatheredCrustElution-DepositedRareEarth Ores, Nova Science Publishers, New York, $288 p$

Deer, W.A., Howie, R.A. and Zussman, J. 1997b. Allanite. In: Rock Forming Minerals. Vol 1B. Disilicates and Ring Silicates, London, The Geological Society, 151-179.

Freitas, M. E. 2000. A Evolução dos Greisens e Mineralização Estanífera no Morro do Laranjinha - Maciço Granítico Mangabeira - Goiás. Universidade de Brasília (Ph. D. Thesis)

Forster, H. J. 2000. Cerite-(Ce) and thorian synchisite-(Ce) from the Niederbobritzsch granite, Erzgebirge, Germany: Implications for the differential mobility of the LREE and Th during alteration. Can. Mineral. 38, 67-69 
Finger, F., Broska, I., Roberts, M. P., Schermaier, A., 1998. Replacement of primary monazite by apatite-allanite-epidote coronas in an amphibolite facies granite gneiss from the Eastern Alps. Am. Mineral. 83, 248-258

Gieré, R. 1996. Formation of rare earth minerals in hydrotermal systems. In:Jones, A.P.; Wall, F. and Williams, C. L. (ed). Rare earth minerals- Chemestry, Origin and Ore deposits. Chapman \& Hall, London, 105-150

Gieré, R., Williams, C.T., Braun, M., Graeser, S., 1998. Complexzonation patterns in monazite$(\mathrm{Nd})$ and monazite-(Ce). 17th General Meeting of the International Mineralogical Association, August 9-14, 1998, Toronto, Abstracts and programe, p. A85

Hogarth, D.D. 1977. Classification and nomenclature of the pyroclore group. Amer. Mineral., 62, 403-410.

Ibrahim, M.E.A., El-Kalioby, B.A.E.H., Aly, G.M., El-Tohamy, A.M., Watanabe, K., 2015. Altered granitic rocks, Nusab El Balgum Area, Southwestern Desert, Egypt: Mineralogical and geochemical aspects of REEs. Ore Geol. Rev. 70, 252-261.

Ito, J. 1968. Silicate apatites and oxyapatites. Am. Mineral. 53, 890-907

Johan, Z., Johan, V. 1994. Oxyfluorures de terres rares de la coupole granitique de Cinovec (Zinwald), République Tchèque. Comptes Rendus de l'Académie des Sciences de Paris, t.318, série Il:1333-1340.

Kamineni, D. C. y Bonardy, M. 1983. Bastnaesite in fractures of the Eye-Dashwa Lakes Pluton, Atikokan, Northwestern Ontario. Can. Mineral., 21,115-119

Kanazawa, Y., Kamitami, M., 2006. Rare earth minerals and resources in the world. J. Alloys Compd. 408-412, 1339-1343.

Lenharo, S.L.R., Moura, A. M., Botelho, N.F., 2002. Petrogenetic and mineralization processes in Paleo to Mesoproterozoic rapakivi granites: examples from Pitinga and Goiás, Brazil. Prec. Res. 119,277-299.

Linthout, K. (2007). Discreditation of brabantite, and recognition of cheralite as the name for members dominated by CaTh (PO 4) Can. Mineral. 45 (2), 503-508

Littlejohn, A. L. 1981. Alteration products of accessory allanite in radioactive granites from the Canadian Shield. Geological Survey of Canada Professional Paper. Current research, Part B, paper 81-1B, p.95-104.

Marini, O.J.; Botelho, N.F. 1986. A Província de Granitos Estaníferos de Goiás. Revista Brasileira de Geociências 16,119 - 131.

Moura, M.A., Botelho, N.F., Olivo, G.R., Kyser, K., Pontes, R.M. 2014. Genesis of the Proterozoic Mangabeira tin-indium mineralization, Central Brazil: Evidence from geology, petrology, fluid inclusion and stable isotope data. Ore Geol. Rev. 60,36-49. 
Moura, M. A. 1993. A zona greisenizada principal do maciço estanífero Mangabeira (Go): Geologia, petrologia e ocorrência de índio. Universidade de Brasília. (M. Sc. Diss.)

Ni, Y., Hughes J. M., Mariano, A. M. 1995, Crystal chemistry of the monazite and xenotime structures. Am. Mineral., 37, 137, 157.

Pointer, C. M., Ashworth, J. R., Ixer, R.A., 1988. The zircon-thorite mineral group in metasomatized granite, Ririwai, Nigeria 1. Geochemistry and metastable solid solution of thorite and coffinite. Mineralogy and Petrology 38, 245-262

Rocha, A.; Schissel, D.; Sprecher, A.; Tarso, P. and J. Goode, J., 2013. Process Development for the Serra VerdeWeathered Crust Elution-deposited Rare Earth Deposit in Brazil.In: I. London, J. Goode, G. Moldoveanu and M.Rayat (eds), Rare Earth Elements - Proceedings of the 52nd Conference of Metallurgists (COM 2013). Metallurgical Society of the Canadian Institute of Mining, Metallurgy and Petroleum (MetSoc-CIM), Montreal, Canada, 2013.

Ronsbo, J. G. - 1989 - Coupled substitutions involving REEs and $\mathrm{Na}$ and $\mathrm{Si}$ in apatites in alkaline rocks from de llímaussaq intrusion, South Greenland, and the petrological implications. Am. Mineral. 74: 896 - 901.

Rubin, J.N., Henry, C.H., Price, J.G., 1989. Hidrotermal zircons and circón overgrowths, Sierra Blanca Peaks, Texas. Am. Mineral. 74, 865-869.

Sanematsu K., Murakami H., Watanabe Y., Duangsurigna S., Vilayhack S. 2009. Enrichment of rare earth elements (REE) in granitic rocks and their weathered crusts in central and southern Laos.Bulletin of the Geological Survey of Japan, 60, 527-558.

Sanematsu K., Kon Y., Imai A., Watanabe K., Watanabe Y. 2013. Geochemical and mineralogical characteristics of ion-adsorption type REE mineralization in Phuket, Thailand. Miner. Deposita, 48,437-451.

Santana, I.V.; Wall, F; Botelho, N.F. 2015 Occurrence and behavior of monazite and xenotime in detrital and saprolitic environments related to an A-type granite, Goiás/Tocantins, Brazil: potential for REE deposits. Journal of Geochemical Exploration. 155,1-13.

Scherrer, N.C.; Engi, M.; Gnos, E.; Jakob, V. \& Leichti, A. 2000 Monazite analisys: from sample preparation to microprobe age dating and REE quantification. Schweizerische Mineralogische und Petrographische Mitteilungen. 80. 93-105.

Speer, J.A. 1982. The actinide orthosilicates. In: Ribbe, P.H. (Ed.), Orthosilicates, Reviews in Mineralogy, vol. 5. Mineralogical Society of America, Washington, DC, pp.113-135

Staritzky, E.; Asprey, L.B. 1957. Lanthanum trifluoride, LaF3 and neodymium trifluoride, NdF3. Analytical Chemistry, 29, 856-857

Styles, M. T. e Young, B. R. 1983. Fluocerite and its alteration products from the Afu Hills, Nigeria. Min. Mag. 47, 41-46. 
Sun, S.S. and McDonough, W.F. 1989. Chemical and isotopicsystematics of oceanicbasalts; implicationsformantlecomposition and processes. In: Saunders, A.D. and Norry, M.J. (Editors)Magmatism in theoceanbasins., Geological Society of London, 42, 313-345.

Teixeira, L.M., Botelho, N.F., 2006. Comportamento geoquímico de ETR durante a evolução magmática e alteração hidrotermal de granitos: Exemplos da Província Estanífera De Goiás. Revista Brasileira de Geociências 36 (4), 679-691.

Teixeira, L.M., Botelho, N.F., 2002. Comportamento cristaloquímico de monazita primária e hidrotermal durante a evolução de granitos e greisens: Exemplos das subprovíncias Tocantins e Paranã, Goiás. Revista Brasileira de Geociências 32,335-342

Teixeira, L. M. 2002. Caracterização de minerais portadores de terras raras e sua aplicação à petrologia e geocronologia de granitos das subprovíncias Tocantins e Paranã - Goiás. Instituto de Geociências, Universidade de Brasília (Ph. D. Thesis).

Williams-Jones, E. A. and Woods, S. A. 1992. A preliminary petrogenetic grid for REE fluocarbonates and associated minerals. Geochimica et cosmochimica Acta, 56, 725-738-

Wang, L., Xu, C., Zhao, Z., Song, W., Kynicky, J., 2015. Petrological and geochemical characteristics of Zhaibei granites in Nanling region, Southeast China: Implications for REE mineralization. Ore Geol. Rev. 64,569-582.

Wood, S.A. and Rickets, A. 2000. Allanite-(Ce) from the Eocene Casto granite, Idaho: Response to hydrotermal alteration. Can. Mineral. 38, 81-100

Woodhead, J.A., Rossman, G.R., Silver, L.T.1991. The metamictization of zircon: Radation dose-dependent structural characteistics. Am. Mineral. 76, 74-82

Wu, C. G., Huang, D. H. and Guo, Z. G. 1990. REE geochemistry in the weathered crust of granites, Longnan área, Jiangxi Province. Acta Geol. Sinica, 3, 193-21

Yang, X.J., Lin, A., Li, X., Wu, Y., Zhou, W., Chen, Z., 2013. China ion-adsorption rare earth resources, mining consequences and preservation. Environ. Dev. 8, 131-136. 
10. ANEXOS

10.1 QUÍMICA MINERAL PARA FLUOCERITAS

Fuoreritas-Fácies PB1c

\begin{tabular}{|c|c|c|c|c|c|c|c|c|c|}
\hline & $\begin{array}{c}\text { AZME4B } \\
\text { C2 } \mathrm{fl} 1\end{array}$ & $\begin{array}{c}\text { AZME4B } \\
\mathrm{C} 2 \mathrm{fl} 2\end{array}$ & $\begin{array}{l}\text { AZME4B } \\
\text { C4 fora }\end{array}$ & $\begin{array}{c}\text { AZME4B } \\
\text { C5 fl } 1\end{array}$ & $\begin{array}{c}\text { AZME4b } \\
\text { C2 fl } 2\end{array}$ & $\begin{array}{c}\text { AZME4b } \\
\text { C2 fl } 6\end{array}$ & $\begin{array}{c}\text { AZME4b } \\
\text { C2 fl } 7\end{array}$ & $\begin{array}{c}\text { AZME4b } \\
\text { C2 fl } 8\end{array}$ & $\begin{array}{c}\text { AZME4b } \\
\text { C2 fl } 9\end{array}$ \\
\hline $\mathbf{P}$ & 0,24 & 0,02 & 0,03 & 0,14 & 0,45 & 0,29 & 0,10 & 0,03 & 0,00 \\
\hline Si & 0,05 & 0,02 & 0,14 & 0,21 & 0,16 & 0,52 & 0,35 & 0,06 & 0,05 \\
\hline $\mathbf{Y}$ & 0,15 & 0,18 & 0,15 & 0,22 & 0,28 & 0,29 & 0,12 & 0,22 & 0,23 \\
\hline $\mathrm{Fe}$ & 0,09 & 0,06 & 0,01 & 0,09 & 0,19 & 0,24 & 0,07 & 0,02 & 0,01 \\
\hline $\mathrm{Ca}$ & 0,76 & 0,04 & 0,40 & 0,50 & 1,26 & 0,55 & 0,86 & 0,60 & 0,23 \\
\hline $\mathbf{F}$ & 15,97 & 13,21 & 14,78 & 12,11 & 13,27 & 16,76 & 13,41 & 11,98 & 15,80 \\
\hline La & 12,83 & 25,57 & 20,53 & 14,17 & 21,84 & 27,73 & 18,42 & 20,92 & 27,57 \\
\hline $\mathrm{Ce}$ & 51,02 & 44,35 & 42,88 & 46,77 & 42,12 & 35,25 & 45,27 & 48,00 & 42,86 \\
\hline Pr & 1,79 & 2,16 & 3,04 & 2,50 & 2,48 & 2,82 & 2,64 & 2,18 & 2,41 \\
\hline Nd & 6,25 & 5,55 & 9,22 & 9,10 & 6,61 & 8,20 & 8,65 & 5,70 & 6,08 \\
\hline Sm & 1,16 & 0,63 & 1,00 & 1,11 & 0,58 & 0,82 & 1,03 & 0,46 & 0,46 \\
\hline Eu & 0,39 & 0,40 & 0,66 & 0,48 & 0,36 & 0,51 & 0,49 & 0,36 & 0,38 \\
\hline Gd & 1,46 & 0,30 & 0,60 & 1,34 & 0,38 & 0,00 & 0,92 & 0,68 & 0,37 \\
\hline $\mathrm{Tb}$ & 0,02 & 0,03 & 0,07 & 0,00 & 0,00 & 0,00 & 0,00 & 0,03 & 0,00 \\
\hline Dy & 0,01 & 0,01 & 0,00 & 0,00 & 0,00 & 0,05 & 0,00 & 0,08 & 0,00 \\
\hline Ho & 0,00 & 0,00 & 0,00 & 0,23 & 0,00 & 0,00 & 0,00 & 0,03 & 0,00 \\
\hline Er & 0,03 & 0,00 & 0,03 & 0,07 & 0,04 & 0,03 & 0,00 & 0,07 & 0,00 \\
\hline $\mathrm{Tm}$ & 0,00 & 0,00 & 0,00 & 0,12 & 0,00 & 0,00 & 0,00 & 0,03 & 0,01 \\
\hline $\mathrm{Yb}$ & 0,01 & 0,06 & 0,00 & 0,00 & 0,01 & 0,00 & 0,09 & 0,00 & 0,07 \\
\hline Lu & 0,00 & 0,00 & 0,00 & 0,04 & 0,00 & 0,10 & 0,00 & 0,04 & 0,04 \\
\hline Th & 4,12 & 2,21 & 3,26 & 4,35 & 3,97 & 3,12 & 3,01 & 2,45 & 1,62 \\
\hline $\mathrm{Pb}$ & 0,17 & 0,25 & 0,49 & 0,38 & 0,73 & 0,30 & 0,40 & 0,64 & 0,23 \\
\hline Total & 96,84 & 95,18 & 97,84 & 94,50 & 95,09 & 97,89 & 96,13 & 94,71 & 98,53 \\
\hline REE+Y & 75,13 & 79,24 & 78,18 & 76,16 & 74,69 & 75,79 & 77,62 & 78,81 & 80,47 \\
\hline LREE & 73,45 & 78,66 & 77,33 & 74,14 & 73,99 & 75,33 & 76,50 & 77,63 & 79,75 \\
\hline HREE+Y & 1,68 & 0,58 & 0,85 & 2,03 & 0,70 & 0,46 & 1,12 & 1,18 & 0,72 \\
\hline \multicolumn{10}{|c|}{ Fórmula calculada com base em quatro iones } \\
\hline $\mathbf{P}$ & 0,021 & 0,002 & 0,003 & 0,015 & 0,044 & 0,025 & 0,010 & 0,003 & 0,000 \\
\hline Si & 0,005 & 0,003 & 0,014 & 0,024 & 0,017 & 0,050 & 0,038 & 0,007 & 0,005 \\
\hline $\mathbf{Y}$ & 0,005 & 0,006 & 0,005 & 0,008 & 0,009 & 0,009 & 0,004 & 0,008 & 0,007 \\
\hline $\mathrm{Fe}$ & 0,004 & 0,003 & 0,000 & 0,005 & 0,011 & 0,012 & 0,004 & 0,001 & 0,001 \\
\hline $\mathrm{Ca}$ & 0,053 & 0,003 & 0,029 & 0,040 & 0,095 & 0,037 & 0,065 & 0,049 & 0,016 \\
\hline $\mathbf{F}$ & 2,353 & 2,178 & 2,268 & 2,065 & 2,116 & 2,367 & 2,142 & 2,057 & 2,337 \\
\hline La & 0,259 & 0,577 & 0,431 & 0,331 & 0,476 & 0,536 & 0,402 & 0,491 & 0,558 \\
\hline $\mathrm{Ce}$ & 1,019 & 0,992 & 0,892 & 1,082 & 0,911 & 0,675 & 0,980 & 1,117 & 0,860 \\
\hline $\operatorname{Pr}$ & 0,036 & 0,048 & 0,063 & 0,058 & 0,053 & 0,054 & 0,057 & 0,051 & 0,048 \\
\hline Nd & 0,121 & 0,121 & 0,186 & 0,204 & 0,139 & 0,152 & 0,182 & 0,129 & 0,118 \\
\hline Sm & 0,022 & 0,013 & 0,019 & 0,024 & 0,012 & 0,015 & 0,021 & 0,010 & 0,009 \\
\hline Eu & 0,007 & 0,008 & 0,013 & 0,010 & 0,007 & 0,009 & 0,010 & 0,008 & 0,007 \\
\hline Gd & 0,026 & 0,006 & 0,011 & 0,028 & 0,007 & 0,000 & 0,018 & 0,014 & 0,007 \\
\hline $\mathrm{Tb}$ & 0,000 & 0,001 & 0,001 & 0,000 & 0,000 & 0,000 & 0,000 & 0,001 & 0,000 \\
\hline Dy & 0,000 & 0,000 & 0,000 & 0,000 & 0,000 & 0,001 & 0,000 & 0,002 & 0,000 \\
\hline Ho & 0,000 & 0,000 & 0,000 & 0,005 & 0,000 & 0,000 & 0,000 & 0,001 & 0,000 \\
\hline Er & 0,000 & 0,000 & 0,001 & 0,001 & 0,001 & 0,000 & 0,000 & 0,001 & 0,000 \\
\hline $\mathrm{Tm}$ & 0,000 & 0,000 & 0,000 & 0,002 & 0,000 & 0,000 & 0,000 & 0,001 & 0,000 \\
\hline $\mathrm{Yb}$ & 0,000 & 0,001 & 0,000 & 0,000 & 0,000 & 0,000 & 0,002 & 0,000 & 0,001 \\
\hline Lu & 0,000 & 0,000 & 0,000 & 0,001 & 0,000 & 0,001 & 0,000 & 0,001 & 0,001 \\
\hline Th & 0,050 & 0,030 & 0,041 & 0,061 & 0,052 & 0,036 & 0,039 & 0,034 & 0,020 \\
\hline $\mathrm{Pb}$ & 0,002 & 0,004 & 0,007 & 0,006 & 0,011 & 0,004 & 0,006 & 0,010 & 0,003 \\
\hline Total & 4 & 4 & 4 & 4 & 4 & 4 & 4 & 4 & 4 \\
\hline
\end{tabular}


10.2 QUÍMICA MINERAL PARA BASTNAESITAS

Bastnaesitas-Fácies PB1c

Bastnaesita- $(\mathrm{Y})$

\begin{tabular}{|c|c|c|c|c|c|c|c|c|c|c|c|c|c|c|c|c|c|c|}
\hline & $\begin{array}{r}\text { AZME- } \\
4 A .1\end{array}$ & $\begin{array}{r}\text { AZME- } \\
4 \text { A. } 2\end{array}$ & $\begin{array}{r}\text { AZME- } \\
4 A .3\end{array}$ & $\begin{array}{r}\text { AZME- } \\
4 \mathrm{~A} .4\end{array}$ & $\begin{array}{r}\text { AZME- } \\
4 \text { A. } 5\end{array}$ & $\begin{array}{r}\text { AZME- } \\
4 \text { A.6 }\end{array}$ & $\begin{array}{r}\text { AZME- } \\
4 \mathrm{~A} .7\end{array}$ & $\begin{array}{r}\text { AZME- } \\
4 \text { A. } 8\end{array}$ & $\begin{array}{r}\text { AZME- } \\
4 \text { A.9 }\end{array}$ & $\begin{array}{r}\text { AZME- } \\
4 A .10\end{array}$ & $\begin{array}{r}\text { AZME- } \\
4 A .11\end{array}$ & $\begin{array}{l}\text { AZME- } \\
\text { 04B.1 }\end{array}$ & $\begin{array}{l}\text { AZME- } \\
\text { 04B.2 }\end{array}$ & $\begin{array}{l}\text { AZME- } \\
\text { 04B.3 }\end{array}$ & $\begin{array}{r}\text { AZME- } \\
\text { 04B.4 }\end{array}$ & $\begin{array}{r}\text { ME10A } \\
\text { C2 } 3\end{array}$ & $\begin{array}{r}\text { ME10A } \\
\text { C3 } 1\end{array}$ & $\begin{array}{r}\mathrm{ME} 10 \mathrm{~A} \\
\mathrm{C} 33\end{array}$ \\
\hline $\mathrm{P}_{2} \mathrm{O}_{5}$ & 2,28 & 0,19 & 0,12 & 1,15 & 0,37 & 1,59 & 2,56 & 1,66 & 0,07 & 1,14 & 1,23 & 0,92 & 0,72 & 0,82 & 0,44 & 0,00 & 0,03 & 0,04 \\
\hline $\mathrm{Y}_{2} \mathrm{O}_{3}$ & 0,31 & 0,35 & 0,00 & 0,24 & 0,05 & 0,13 & 0,16 & 0,14 & 0,05 & 0,03 & 0,03 & 0,15 & 0,16 & 0,28 & 0,40 & 19,53 & 19,33 & 14,50 \\
\hline $\mathrm{CaO}$ & 0,30 & 0,65 & 0,28 & 0,41 & 0,64 & 0,85 & 0,80 & 0,45 & 0,24 & 0,53 & 0,24 & 0,75 & 1,36 & 1,07 & 1,07 & 1,81 & 1,46 & 3,36 \\
\hline $\mathbf{F}$ & 5,66 & 6,05 & 6,42 & 4,67 & 4,96 & 6,55 & 6,03 & 4,12 & 5,77 & 4,93 & 2,47 & 5,94 & 2,47 & 7,11 & 2,95 & 4,80 & 6,05 & 7,27 \\
\hline $\mathrm{La}_{2} \mathrm{O}_{3}$ & 17,08 & 22,96 & 18,22 & 12,73 & 27,23 & 18,20 & 13,18 & 14,18 & 19,70 & 17,15 & 8,90 & 16,78 & 0,92 & 13,44 & 1,22 & 11,74 & 11,65 & 6,60 \\
\hline $\mathrm{Ce}_{2} \mathrm{O}_{3}$ & 42,24 & 45,79 & 45,63 & 37,92 & 45,30 & 41,62 & 35,37 & 37,16 & 45,40 & 42,58 & 46,98 & 46,84 & 76,16 & 57,19 & 67,77 & 1,79 & 1,74 & 17,50 \\
\hline $\mathrm{Pr}_{2} \mathrm{O}_{3}$ & 2,58 & 2,29 & 2,98 & 2,28 & 2,77 & 2,53 & 2,21 & 2,16 & 2,71 & 2,78 & 1,46 & 2,42 & 0,54 & 2,52 & 0,42 & 2,31 & 2,06 & 1,37 \\
\hline $\mathrm{Nd}_{2} \mathrm{O}_{3}$ & 8,19 & 6,29 & 10,04 & 7,05 & 7,02 & 7,77 & 6,81 & 6,95 & 8,39 & 8,53 & 5,00 & 7,85 & 3,31 & 8,81 & 2,93 & 9,76 & 8,88 & 5,98 \\
\hline $\mathrm{Sm}_{2} \mathrm{O}_{3}$ & 0,69 & 0,60 & 0,87 & 0,51 & 0,51 & 0,74 & 0,64 & 0,79 & 0,77 & 0,92 & 0,77 & 0,83 & 1,44 & 1,42 & 0,96 & 1,92 & 1,81 & 1,63 \\
\hline $\mathrm{Eu}_{2} \mathrm{O}_{3}$ & 0,27 & 0,42 & 0,33 & 0,35 & 0,49 & 0,29 & 0,32 & 0,32 & 0,40 & 0,41 & 0,20 & 0,38 & 0,02 & 0,40 & 0,01 & 0,38 & 0,38 & 0,29 \\
\hline $\mathrm{Gd}_{2} \mathrm{O}_{3}$ & 0,00 & 0,00 & 0,00 & 0,00 & 0,00 & 0,00 & 0,00 & 0,00 & 0,00 & 0,00 & 0,00 & 0,00 & 1,77 & 0,27 & 1,20 & 2,75 & 2,19 & 2,06 \\
\hline $\mathrm{Tb}_{2} \mathrm{O}_{3}$ & 0,00 & 0,00 & 0,00 & 0,00 & 0,00 & 0,00 & 0,00 & 0,00 & 0,00 & 0,00 & 0,00 & 0,00 & 0,00 & 0,00 & 0,00 & 0,30 & 0,20 & 0,00 \\
\hline $\mathrm{Dy}_{2} \mathrm{O}_{3}$ & 0,00 & 0,00 & 0,00 & 0,00 & 0,00 & 0,00 & 0,00 & 0,00 & 0,00 & 0,00 & 0,00 & 0,00 & 0,00 & 0,11 & 0,09 & 5,42 & 4,80 & 2,74 \\
\hline $\mathrm{Ho}_{2} \mathrm{O}_{3}$ & 0,01 & 0,05 & 0,00 & 0,00 & 0,00 & 0,00 & 0,00 & 0,09 & 0,13 & 0,03 & 0,03 & 0,13 & 0,00 & 0,08 & 0,00 & 1,08 & 1,07 & 0,63 \\
\hline $\mathrm{Er}_{2} \mathrm{O}_{3}$ & 0,04 & 0,04 & 0,02 & 0,00 & 0,03 & 0,01 & 0,00 & 0,00 & 0,00 & 0,13 & 0,00 & 0,00 & 0,04 & 0,04 & 0,09 & 3,06 & 2,64 & 1,68 \\
\hline $\mathrm{Tm}_{2} \mathrm{O}_{3}$ & 0,00 & 0,04 & 0,06 & 0,00 & 0,00 & 0,00 & 0,00 & 0,00 & 0,07 & 0,03 & 0,00 & 0,00 & 0,00 & 0,07 & 0,00 & 0,62 & 0,39 & 0,36 \\
\hline $\mathrm{Yb}_{2} \mathrm{O}_{3}$ & 0,00 & 0,00 & 0,02 & 0,02 & 0,00 & 0,02 & 0,00 & 0,00 & 0,00 & 0,02 & 0,00 & 0,00 & 0,01 & 0,00 & 0,02 & 2,50 & 2,15 & 1,23 \\
\hline $\mathrm{Lu}_{2} \mathrm{O}_{3}$ & 0,00 & 0,01 & 0,00 & 0,03 & 0,00 & 0,06 & 0,00 & 0,01 & 0,06 & 0,00 & 0,01 & 0,00 & 0,13 & 0,00 & 0,06 & 0,55 & 0,55 & 0,34 \\
\hline $\mathrm{ThO}_{2}$ & 8,26 & 2,60 & 1,90 & 6,60 & 2,51 & 7,58 & 8,64 & 5,93 & 1,94 & 3,60 & 4,18 & 4,84 & 5,72 & 4,26 & 6,14 & 0,08 & 2,59 & 7,01 \\
\hline $\mathrm{F}=\mathrm{O}_{2}$ & 2,38 & 2,55 & 2,70 & 1,97 & 2,09 & 2,76 & 2,54 & 1,73 & 2,43 & 2,08 & 1,04 & 2,50 & 1,04 & 3,00 & 1,24 & 2,02 & 2,55 & 3,06 \\
\hline Total & 88,97 & 86,44 & 85,17 & 75,01 & 90,63 & 88,01 & 78,40 & 75,09 & 84,06 & 82,55 & 73,35 & 89,68 & 95,07 & 97,90 & 86,35 & 71,47 & 68,76 & 81,69 \\
\hline$R E E+Y$ & 71,42 & 78,84 & 78,17 & 61,13 & 83,39 & 71,36 & 58,68 & 61,80 & 77,67 & 72,60 & 63,37 & 75,39 & 84,48 & 84,63 & 75,15 & 63,72 & 59,85 & 56,89 \\
\hline LREE & 71,06 & 78,35 & 78,07 & 60,83 & 83,32 & 71,14 & 58,52 & 61,56 & 77,37 & 72,36 & 63,31 & 75,11 & 82,37 & 83,78 & 73,30 & 27,90 & 26,52 & 33,36 \\
\hline HREE+Y & 0,36 & 0,48 & 0,11 & 0,29 & 0,08 & 0,22 & 0,16 & 0,24 & 0,30 & 0,23 & 0,07 & 0,29 & 2,11 & 0,84 & 1,85 & 35,82 & 33,33 & 23,54 \\
\hline \multicolumn{19}{|c|}{ Fórmula calculada com base em 1 cátion. -Em todos os análises o conteúdo de C é equivalente a 1 a.f.u. } \\
\hline $\mathbf{P}$ & 0,037 & 0,003 & 0,002 & 0,023 & 0,006 & 0,027 & 0,045 & 0,032 & 0,001 & 0,021 & 0,024 & 0,015 & 0,011 & 0,013 & 0,008 & 0,000 & 0,001 & 0,001 \\
\hline $\mathbf{Y}$ & 0,002 & 0,002 & 0,000 & 0,002 & 0,000 & 0,001 & 0,001 & 0,001 & 0,000 & 0,000 & 0,000 & 0,001 & 0,001 & 0,001 & 0,002 & 0,121 & 0,127 & 0,071 \\
\hline $\mathrm{Ca}$ & 0,006 & 0,015 & 0,007 & 0,010 & 0,014 & 0,018 & 0,018 & 0,011 & 0,006 & 0,012 & 0,006 & 0,016 & 0,027 & 0,021 & 0,024 & 0,045 & 0,038 & 0,066 \\
\hline$F$ & 0,341 & 0,413 & 0,449 & 0,343 & 0,317 & 0,410 & 0,398 & 0,292 & 0,410 & 0,334 & 0,178 & 0,370 & 0,147 & 0,418 & 0,196 & 0,355 & 0,470 & 0,423 \\
\hline La & 0,120 & 0,183 & 0,148 & 0,109 & 0,203 & 0,133 & 0,102 & 0,117 & 0,163 & 0,136 & 0,075 & 0,122 & 0,006 & 0,092 & 0,009 & 0,101 & 0,106 & 0,045 \\
\hline $\mathrm{Ce}$ & 0,295 & 0,362 & 0,369 & 0,323 & 0,335 & 0,302 & 0,271 & 0,305 & 0,374 & 0,334 & 0,393 & 0,338 & 0,525 & 0,389 & 0,520 & 0,015 & 0,016 & 0,118 \\
\hline $\mathrm{Pr}$ & 0,018 & 0,018 & 0,024 & 0,019 & 0,020 & 0,018 & 0,017 & 0,018 & 0,022 & 0,022 & 0,012 & 0,017 & 0,004 & 0,017 & 0,003 & 0,020 & 0,018 & 0,009 \\
\hline Nd & 0,056 & 0,048 & 0,079 & 0,059 & 0,051 & 0,055 & 0,051 & 0,056 & 0,067 & 0,065 & 0,041 & 0,055 & 0,022 & 0,058 & 0,022 & 0,081 & 0,078 & 0,039 \\
\hline Sm & 0,005 & 0,004 & 0,007 & 0,004 & 0,004 & 0,005 & 0,005 & 0,006 & 0,006 & 0,007 & 0,006 & 0,006 & 0,009 & 0,009 & 0,007 & 0,015 & 0,015 & 0,010 \\
\hline $\mathrm{Eu}$ & 0,002 & 0,003 & 0,003 & 0,003 & 0,003 & 0,002 & 0,002 & 0,002 & 0,003 & 0,003 & 0,002 & 0,003 & 0,000 & 0,003 & 0,000 & 0,003 & 0,003 & 0,002 \\
\hline Gd & 0,000 & 0,000 & 0,000 & 0,000 & 0,000 & 0,000 & 0,000 & 0,000 & 0,000 & 0,000 & 0,000 & 0,000 & 0,011 & 0,002 & 0,008 & 0,021 & 0,018 & 0,013 \\
\hline Tb & 0,000 & 0,000 & 0,000 & 0,000 & 0,000 & 0,000 & 0,000 & 0,000 & 0,000 & 0,000 & 0,000 & 0,000 & 0,000 & 0,000 & 0,000 & 0,002 & 0,002 & 0,000 \\
\hline Dy & 0,000 & 0,000 & 0,000 & 0,000 & 0,000 & 0,000 & 0,000 & 0,000 & 0,000 & 0,000 & 0,000 & 0,000 & 0,000 & 0,001 & 0,001 & 0,041 & 0,038 & 0,016 \\
\hline Ho & 0,000 & 0,000 & 0,000 & 0,000 & 0,000 & 0,000 & 0,000 & 0,001 & 0,001 & 0,000 & 0,000 & 0,001 & 0,000 & 0,000 & 0,000 & 0,008 & 0,008 & 0,004 \\
\hline $\mathrm{Er}$ & 0,000 & 0,000 & 0,000 & 0,000 & 0,000 & 0,000 & 0,000 & 0,000 & 0,000 & 0,001 & 0,000 & 0,000 & 0,000 & 0,000 & 0,001 & 0,022 & 0,020 & 0,010 \\
\hline $\mathrm{Tm}$ & 0,000 & 0,000 & 0,000 & 0,000 & 0,000 & 0,000 & 0,000 & 0,000 & 0,000 & 0,000 & 0,000 & 0,000 & 0,000 & 0,000 & 0,000 & 0,005 & 0,003 & 0,002 \\
\hline $\mathrm{Yb}$ & 0,000 & 0,000 & 0,000 & 0,000 & 0,000 & 0,000 & 0,000 & 0,000 & 0,000 & 0,000 & 0,000 & 0,000 & 0,000 & 0,000 & 0,000 & 0,018 & 0,016 & 0,007 \\
\hline Lu & 0,000 & 0,000 & 0,000 & 0,000 & 0,000 & 0,000 & 0,000 & 0,000 & 0,000 & 0,000 & 0,000 & 0,000 & 0,001 & 0,000 & 0,000 & 0,004 & 0,004 & 0,002 \\
\hline Th & 0,036 & 0,013 & 0,010 & 0,035 & 0,012 & 0,034 & 0,041 & 0,030 & 0,010 & 0,018 & 0,022 & 0,022 & 0,025 & 0,018 & 0,029 & 0,000 & 0,015 & 0,029 \\
\hline Total & 0,977 & 1,078 & 1,114 & 0,992 & 0,980 & 1,060 & 1,034 & 0,936 & 1,077 & 0,988 & 0,828 & 1,027 & 0,817 & 1,082 & 0,865 & 0,920 & 1,021 & 1,037 \\
\hline
\end{tabular}




\subsection{QUÍMICA MINERAL PARA OXIFLUORETOS DE ETR}

Oxifluoretos de ETR-Fácies PB1c

\begin{tabular}{|c|c|c|c|c|c|}
\hline & $\begin{array}{c}\text { 05-I- } \\
164 \_C 1 \\
1\end{array}$ & $\begin{array}{c}\text { 05-I- } \\
164 \_C 1 \\
2\end{array}$ & $\begin{array}{c}\text { AZME4b } \\
\text { C2 fl } 3\end{array}$ & $\begin{array}{c}\text { AZME4b } \\
\text { C2 fl } 4\end{array}$ & $\begin{array}{c}\text { AZME4b } \\
\text { C2 fl } 5\end{array}$ \\
\hline $\mathrm{P}_{2} \mathrm{O}_{5}$ & 0,02 & 0,01 & 0,48 & 1,53 & 1,08 \\
\hline $\mathrm{SiO}_{2}$ & 6,72 & 2,44 & 0,15 & 0,09 & 0,25 \\
\hline $\mathrm{TiO}_{2}$ & 8,40 & 1,21 & 0,00 & 0,02 & 0,00 \\
\hline $\mathrm{Al}_{2} \mathrm{O}_{3}$ & 5,05 & 2,14 & 0,12 & 0,15 & 0,13 \\
\hline $\mathrm{Y}_{2} \mathrm{O}_{3}$ & 1,95 & 1,57 & 0,22 & 0,32 & 0,17 \\
\hline $\mathrm{FeO}$ & 0,95 & 0,44 & 0,23 & 0,13 & 0,33 \\
\hline $\mathrm{CaO}$ & 4,69 & 6,05 & 0,69 & 1,30 & 1,28 \\
\hline $\mathbf{F}$ & 7,14 & 9,07 & 5,39 & 5,82 & 4,96 \\
\hline $\mathrm{La}_{2} \mathrm{O}_{3}$ & 9,18 & 13,32 & 15,19 & 19,92 & 16,36 \\
\hline $\mathrm{Ce}_{2} \mathrm{O}_{3}$ & 29,76 & 40,98 & 60,25 & 47,05 & 55,92 \\
\hline $\mathrm{Pr}_{2} \mathrm{O}_{3}$ & 1,64 & 2,41 & 2,38 & 2,82 & 2,53 \\
\hline $\mathrm{Nd}_{2} \mathrm{O}_{3}$ & 6,07 & 8,85 & 7,94 & 8,91 & 8,49 \\
\hline $\mathrm{Sm}_{2} \mathrm{O}_{3}$ & 0,43 & 0,80 & 1,25 & 1,17 & 1,03 \\
\hline $\mathrm{Eu}_{2} \mathrm{O}_{3}$ & 0,37 & 0,51 & 0,43 & 0,59 & 0,41 \\
\hline $\mathrm{Gd}_{2} \mathrm{O}_{3}$ & 0,53 & 0,71 & 1,48 & 0,85 & 1,44 \\
\hline $\mathrm{Tb}_{2} \mathrm{O}_{3}$ & 0,00 & 0,00 & 0,00 & 0,00 & 0,00 \\
\hline $\mathrm{Dy}_{2} \mathrm{O}_{3}$ & 0,22 & 0,04 & 0,02 & 0,00 & 0,00 \\
\hline $\mathrm{Ho}_{2} \mathrm{O}_{3}$ & 0,00 & 0,00 & 0,10 & 0,05 & 0,03 \\
\hline $\mathrm{Er}_{2} \mathrm{O}_{3}$ & 0,28 & 0,15 & 0,00 & 0,00 & 0,03 \\
\hline $\mathrm{Tm}_{2} \mathrm{O}_{3}$ & 0,00 & 0,05 & 0,02 & 0,05 & 0,08 \\
\hline $\mathrm{Yb}_{2} \mathrm{O}_{3}$ & 0,21 & 0,07 & 0,00 & 0,00 & 0,00 \\
\hline $\mathrm{Lu}_{2} \mathrm{O}_{3}$ & 0,16 & 0,09 & 0,08 & 0,00 & 0,00 \\
\hline $\mathrm{ThO}_{2}$ & 2,71 & 2,61 & 3,64 & 2,67 & 3,51 \\
\hline $\mathrm{F}=\mathrm{O}_{2}$ & 3,01 & 3,82 & 2,27 & 2,45 & 2,09 \\
\hline Total & 84,22 & 90,30 & 98,74 & 91,66 & 97,55 \\
\hline$R E E+Y$ & 50,80 & 69,54 & 89,36 & 81,74 & 86,49 \\
\hline LREE & 47,45 & 66,87 & 87,45 & 80,46 & 84,75 \\
\hline HREE+Y & 3,36 & 2,68 & 1,90 & 1,28 & 1,74 \\
\hline \multicolumn{6}{|c|}{ Fórmula calculada com base em 1 cation } \\
\hline $\mathbf{P}$ & 0,000 & 0,000 & 0,008 & 0,025 & 0,018 \\
\hline Si & 0,092 & 0,036 & 0,003 & 0,002 & 0,005 \\
\hline $\mathrm{Ti}$ & 0,173 & 0,027 & 0,000 & 0,001 & 0,000 \\
\hline Al & 0,081 & 0,037 & 0,003 & 0,003 & 0,003 \\
\hline $\mathbf{Y}$ & 0,007 & 0,006 & 0,001 & 0,002 & 0,001 \\
\hline $\mathrm{Fe}$ & 0,011 & 0,005 & 0,004 & 0,002 & 0,005 \\
\hline $\mathrm{Ca}$ & 0,069 & 0,095 & 0,014 & 0,027 & 0,027 \\
\hline $\mathbf{F}$ & 0,309 & 0,420 & 0,324 & 0,353 & 0,304 \\
\hline La & 0,046 & 0,072 & 0,107 & 0,141 & 0,117 \\
\hline $\mathrm{Ce}$ & 0,149 & 0,219 & 0,420 & 0,330 & 0,397 \\
\hline $\mathrm{Pr}$ & 0,008 & 0,013 & 0,017 & 0,020 & 0,018 \\
\hline Nd & 0,030 & 0,046 & 0,054 & 0,061 & 0,059 \\
\hline Sm & 0,002 & 0,004 & 0,008 & 0,008 & 0,007 \\
\hline $\mathrm{Eu}$ & 0,002 & 0,003 & 0,003 & 0,004 & 0,003 \\
\hline Gd & 0,002 & 0,003 & 0,009 & 0,005 & 0,009 \\
\hline Tb & 0,000 & 0,000 & 0,000 & 0,000 & 0,000 \\
\hline Dy & 0,001 & 0,000 & 0,000 & 0,000 & 0,000 \\
\hline Ho & 0,000 & 0,000 & 0,001 & 0,000 & 0,000 \\
\hline Er & 0,001 & 0,001 & 0,000 & 0,000 & 0,000 \\
\hline Tm & 0,000 & 0,000 & 0,000 & 0,000 & 0,000 \\
\hline Yb & 0,001 & 0,000 & 0,000 & 0,000 & 0,000 \\
\hline Lu & 0,001 & 0,000 & 0,000 & 0,000 & 0,000 \\
\hline Th & 0,008 & 0,009 & 0,016 & 0,012 & 0,015 \\
\hline Total & 1 & 1 & 1 & 1 & 1 \\
\hline
\end{tabular}


10.4 QUÍMICA MINERAL PARA MONAZITAS

\begin{tabular}{|c|c|c|c|c|c|c|c|c|c|c|c|c|}
\hline & \multicolumn{8}{|c|}{ Monazitas-Fácies PB1a } & \multicolumn{4}{|c|}{ Monazitas-Fácies PB1c } \\
\hline & $\begin{array}{c}\text { 14ACafe } \\
\text { k11 }\end{array}$ & $\begin{array}{c}\text { ME12_C7 } \\
1\end{array}$ & $\begin{array}{c}\text { AZME12 } \\
\text { B5D_G12 } \\
1\end{array}$ & $\begin{array}{l}\text { AZME12 } \\
\text { B5D_16 2 }\end{array}$ & $\begin{array}{c}\text { AZME12 } \\
\text { B5D_M5 } \\
1\end{array}$ & $\begin{array}{c}\text { AZME12 } \\
\text { B5D_M5 } \\
2\end{array}$ & $\begin{array}{c}\text { ME12_C3 } \\
\mathrm{mz} 1\end{array}$ & $\begin{array}{c}\text { ME12_C5 } \\
\text { mz } 1\end{array}$ & $\begin{array}{c}\text { AZME12 } \\
\text { B5D_J2 } \\
\end{array}$ & $\begin{array}{c}\text { AZME04 } \\
\text { D_C2 mz } \\
1\end{array}$ & $\begin{array}{c}\text { AZME04 } \\
\text { D_C2-3 } \\
\text { mz } 1\end{array}$ & $\begin{array}{c}\text { AZME04 } \\
\text { D_Cf m z } \\
1\end{array}$ \\
\hline $\mathbf{P}_{2} \mathrm{O}_{5}$ & 24,09 & 25,35 & 23,99 & 20,87 & 24,22 & 21,24 & 24,85 & 24,34 & 25,32 & 25,72 & 25,06 & 24,83 \\
\hline $\mathrm{SiO}_{2}$ & 0,99 & 0,57 & 0,57 & 2,56 & 0,60 & 3,92 & 0,45 & 1,73 & 0,23 & 0,22 & 0,30 & 0,32 \\
\hline $\mathrm{ZrO}_{2}$ & 0,45 & 0,68 & 0,57 & 1,10 & 0,59 & 0,51 & 0,37 & 0,51 & 0,48 & 0,56 & 0,79 & 0,40 \\
\hline $\mathrm{Y}_{2} \mathrm{O}_{3}$ & 0,82 & 0,68 & 0,08 & 0,55 & 0,59 & 0,97 & 0,90 & 0,89 & 0,18 & 0,02 & 0,15 & 0,12 \\
\hline $\mathrm{CaO}$ & 1,67 & 1,24 & 1,01 & 0,17 & 0,00 & 0,12 & 1,31 & 1,25 & 0,19 & 0,46 & 0,55 & 0,21 \\
\hline $\mathbf{F}$ & 1,05 & 1,24 & 1,35 & 1,56 & 1,05 & 0,92 & 1,15 & 1,20 & 1,06 & 1,45 & 1,39 & 1,48 \\
\hline $\mathrm{La}_{2} \mathrm{O}_{3}$ & 10,40 & 12,03 & 13,60 & 10,10 & 14,53 & 17,12 & 14,33 & 12,91 & 10,46 & 9,27 & 10,55 & 10,88 \\
\hline $\mathrm{Ce}_{2} \mathrm{O}_{3}$ & 30,80 & 38,19 & 34,28 & 29,23 & 32,99 & 32,63 & 34,10 & 32,23 & 36,30 & 36,73 & 37,43 & 37,33 \\
\hline $\mathrm{Pr}_{2} \mathrm{O}_{3}$ & 2,38 & 2,46 & 2,80 & 2,65 & 3,26 & 2,67 & 3,52 & 3,42 & 4,27 & 4,20 & 4,17 & 4,39 \\
\hline $\mathrm{Nd}_{2} \mathrm{O}_{3}$ & 9,67 & 10,24 & 7,20 & 9,04 & 10,99 & 9,28 & 12,76 & 12,20 & 15,02 & 15,17 & 14,54 & 14,68 \\
\hline $\mathrm{Sm}_{2} \mathrm{O}_{3}$ & 1,52 & 1,61 & 0,74 & 0,97 & 2,00 & 1,55 & 1,48 & 1,29 & 2,35 & 2,59 & 1,98 & 1,92 \\
\hline $\mathrm{Eu}_{2} \mathrm{O}_{3}$ & 0,57 & 0,52 & 0,45 & 0,42 & 0,77 & 0,47 & 0,52 & 0,49 & 0,73 & 0,83 & 0,66 & 0,61 \\
\hline $\mathrm{Gd}_{2} \mathrm{O}_{3}$ & 1,15 & 1,04 & 0,72 & 0,65 & 1,32 & 1,15 & 1,15 & 1,26 & 1,24 & 1,25 & 1,18 & 1,10 \\
\hline $\mathrm{Tb}_{2} \mathrm{O}_{3}$ & 0,00 & 0,05 & 0,04 & 0,00 & 0,19 & 0,00 & 0,00 & 0,00 & 0,12 & 0,08 & 0,11 & 0,01 \\
\hline $\mathrm{Dy}_{2} \mathrm{O}_{3}$ & 0,15 & 0,39 & 0,01 & 0,00 & 0,23 & 0,22 & 0,00 & 0,01 & 0,00 & 0,21 & 0,00 & 0,00 \\
\hline $\mathrm{Ho}_{2} \mathrm{O}_{3}$ & 0,13 & 0,12 & 0,13 & 0,07 & 0,03 & 0,00 & 0,00 & 0,16 & 0,02 & 0,10 & 0,00 & 0,00 \\
\hline $\mathrm{Er}_{2} \mathrm{O}_{3}$ & 0,00 & 0,11 & 0,20 & 0,23 & 0,03 & 0,16 & 0,02 & 0,09 & 0,00 & 0,08 & 0,00 & 0,09 \\
\hline $\mathrm{Tm}_{2} \mathrm{O}_{3}$ & 0,00 & 0,10 & 0,02 & 0,05 & 0,04 & 0,06 & 0,09 & 0,03 & 0,06 & 0,00 & 0,00 & 0,05 \\
\hline $\mathrm{Yb}_{2} \mathrm{O}_{3}$ & 0,02 & 0,06 & 0,07 & 0,30 & 0,00 & 0,00 & 0,00 & 0,00 & 0,00 & 0,00 & 0,00 & 0,00 \\
\hline $\mathrm{Lu}_{2} \mathrm{O}_{3}$ & 0,04 & 0,05 & 0,12 & 0,02 & 0,14 & 0,00 & 0,00 & 0,05 & 0,00 & 0,00 & 0,00 & 0,00 \\
\hline $\mathrm{ThO}_{2}$ & 10,11 & 5,55 & 8,08 & 7,32 & 4,19 & 4,18 & 5,25 & 5,59 & 2,03 & 2,96 & 3,76 & 3,71 \\
\hline $\mathrm{PbO}$ & 0,67 & 0,33 & 0,45 & 0,14 & 0,03 & 0,00 & 0,28 & 0,32 & 0,00 & 0,09 & 0,11 & 0,18 \\
\hline $\mathrm{F}=\mathrm{O}_{2}$ & 0,44 & 0,52 & 0,57 & 0,66 & 0,44 & 0,39 & 0,48 & 0,51 & 0,45 & 0,61 & 0,58 & 0,62 \\
\hline Total & 99,73 & 102,63 & 96,06 & 90,36 & 97,36 & 97,46 & 102,33 & 99,66 & 99,88 & 101,63 & 102,28 & 102,00 \\
\hline REE $+Y$ & 57,65 & 67,63 & 60,45 & 54,27 & 67,09 & 66,29 & 68,87 & 65,03 & 70,75 & 70,51 & 70,76 & 71,17 \\
\hline LREE & 55,34 & 65,04 & 59,07 & 52,40 & 64,53 & 63,72 & 66,72 & 62,54 & 69,12 & 68,78 & 69,32 & 69,80 \\
\hline HREE+Y & 2,31 & 2,59 & 1,38 & 1,87 & 2,56 & 2,56 & 2,16 & 2,49 & 1,62 & 1,73 & 1,45 & 1,37 \\
\hline \multicolumn{13}{|c|}{ Formula estructural calculada com base em 4 oxigênios } \\
\hline $\mathbf{P}$ & 0,873 & 0,887 & 0,900 & 0,821 & 0,899 & 0,778 & 0,881 & 0,868 & 0,911 & 0,913 & 0,893 & 0,892 \\
\hline Si & 0,042 & 0,024 & 0,025 & 0,119 & 0,026 & 0,170 & 0,019 & 0,073 & 0,010 & 0,009 & 0,013 & 0,013 \\
\hline $\mathrm{Zr}$ & 0,009 & 0,014 & 0,012 & 0,025 & 0,013 & 0,011 & 0,008 & 0,011 & 0,010 & 0,011 & 0,016 & 0,008 \\
\hline $\mathbf{Y}$ & 0,009 & 0,007 & 0,001 & 0,007 & 0,007 & 0,011 & 0,010 & 0,010 & 0,002 & 0,000 & 0,002 & 0,001 \\
\hline $\mathrm{Ca}$ & 0,077 & 0,055 & 0,048 & 0,008 & 0,000 & 0,005 & 0,059 & 0,056 & 0,008 & 0,020 & 0,025 & 0,009 \\
\hline $\mathbf{F}$ & 0,142 & 0,161 & 0,189 & 0,229 & 0,146 & 0,125 & 0,152 & 0,160 & 0,143 & 0,193 & 0,185 & 0,198 \\
\hline La & 0,164 & 0,183 & 0,222 & 0,173 & 0,235 & 0,273 & 0,221 & 0,201 & 0,164 & 0,143 & 0,164 & 0,170 \\
\hline $\mathrm{Ce}$ & 0,482 & 0,578 & 0,556 & 0,497 & 0,529 & 0,517 & 0,523 & 0,497 & 0,565 & 0,564 & 0,576 & 0,580 \\
\hline $\mathrm{Pr}$ & 0,037 & 0,037 & 0,045 & 0,045 & 0,052 & 0,042 & 0,054 & 0,053 & 0,066 & 0,064 & 0,064 & 0,068 \\
\hline Nd & 0,148 & 0,151 & 0,114 & 0,150 & 0,172 & 0,143 & 0,191 & 0,184 & 0,228 & 0,227 & 0,218 & 0,222 \\
\hline Sm & 0,022 & 0,023 & 0,011 & 0,016 & 0,030 & 0,023 & 0,021 & 0,019 & 0,034 & 0,037 & 0,029 & 0,028 \\
\hline Eu & 0,008 & 0,007 & 0,007 & 0,007 & 0,011 & 0,007 & 0,007 & 0,007 & 0,011 & 0,012 & 0,010 & 0,009 \\
\hline Gd & 0,017 & 0,014 & 0,011 & 0,010 & 0,019 & 0,017 & 0,016 & 0,018 & 0,017 & 0,017 & 0,016 & 0,015 \\
\hline $\mathbf{T b}$ & 0,000 & 0,001 & 0,001 & 0,000 & 0,003 & 0,000 & 0,000 & 0,000 & 0,002 & 0,001 & 0,002 & 0,000 \\
\hline Dy & 0,002 & 0,005 & 0,000 & 0,000 & 0,003 & 0,003 & 0,000 & 0,000 & 0,000 & 0,003 & 0,000 & 0,000 \\
\hline Ho & 0,002 & 0,002 & 0,002 & 0,001 & 0,000 & 0,000 & 0,000 & 0,002 & 0,000 & 0,001 & 0,000 & 0,000 \\
\hline Er & 0,000 & 0,001 & 0,003 & 0,003 & 0,000 & 0,002 & 0,000 & 0,001 & 0,000 & 0,001 & 0,000 & 0,001 \\
\hline $\mathrm{Tm}$ & 0,000 & 0,001 & 0,000 & 0,001 & 0,001 & 0,001 & 0,001 & 0,000 & 0,001 & 0,000 & 0,000 & 0,001 \\
\hline $\mathrm{Yb}$ & 0,000 & 0,001 & 0,001 & 0,004 & 0,000 & 0,000 & 0,000 & 0,000 & 0,000 & 0,000 & 0,000 & 0,000 \\
\hline Lu & 0,001 & 0,001 & 0,002 & 0,000 & 0,002 & 0,000 & 0,000 & 0,001 & 0,000 & 0,000 & 0,000 & 0,000 \\
\hline Th & 0,098 & 0,052 & 0,081 & 0,077 & 0,042 & 0,041 & 0,050 & 0,054 & 0,020 & 0,028 & 0,036 & 0,036 \\
\hline $\mathbf{P b}$ & 0,008 & 0,004 & 0,005 & 0,002 & 0,000 & 0,000 & 0,003 & 0,004 & 0,000 & 0,001 & 0,001 & 0,002 \\
\hline Total & 2,199 & 2,224 & 2,239 & 2,307 & 2,192 & 2,201 & 2,223 & 2,222 & 2,201 & 2,253 & 2,252 & 2,261 \\
\hline 0 & 4 & 4 & 4 & 4 & 4 & 4 & 4 & 4 & 4 & 4 & 4 & 4 \\
\hline
\end{tabular}




\subsection{QUÍMICA MINERAL PARA ALLANITAS}

\begin{tabular}{|c|c|c|c|c|c|c|c|c|c|c|c|c|c|c|c|c|c|}
\hline & \multicolumn{13}{|c|}{ Allanitas-Fácies PB1a } & \multicolumn{4}{|c|}{ Allanitas-Fácies PB1c } \\
\hline & \multicolumn{8}{|c|}{ AZME8C- AZME8C- AZME8C- AZME8C- AZME8C- AZME8C- AZME8C- AZME14 } & $\begin{array}{c}\text { AZME14 } \\
\text { C-2 }\end{array}$ & $\begin{array}{c}\text { AZME14 } \\
\text { C-3 }\end{array}$ & $\begin{array}{c}\text { AZME14 } \\
\text { C-4 }\end{array}$ & ME12-1 & $\begin{array}{c}05-\mathrm{I}-164- \\
1\end{array}$ & $\begin{array}{c}\text { ME10DV- } \\
1\end{array}$ & $\begin{array}{c}\text { ME10D- } \\
1 \\
\end{array}$ & \multirow{2}{*}{$\begin{array}{c}\text { ME10D- } \\
2 \\
0,00\end{array}$} & $\begin{array}{c}\text { ME10D- } \\
3\end{array}$ \\
\hline $\mathrm{P}_{2} \mathrm{O}_{5}$ & 0,13 & 0,04 & 1,54 & 1,85 & 1,47 & 0,67 & 1,08 & 0,00 & 0,11 & 0,10 & 0,02 & 0,09 & 0,04 & 0,00 & 0,03 & & 0,01 \\
\hline $\mathrm{SiO}_{2}$ & 30,77 & 29,12 & 30,25 & 28,60 & 29,89 & 30,68 & 33,20 & 29,49 & 26,78 & 27,20 & 28,66 & 29,65 & 27,23 & 25,68 & 29,03 & 33,24 & 29,60 \\
\hline $\mathrm{ZrO}_{2}$ & 0,00 & 0,00 & 0,00 & 0,00 & 0,00 & 0,00 & 0,00 & 0,00 & 0,00 & 0,00 & 0,00 & 0,00 & 0,00 & 0,00 & 0,01 & 0,00 & 0,00 \\
\hline $\mathrm{TiO}_{2}$ & 1,65 & 0,52 & 0,43 & 0,66 & 0,29 & 0,37 & 0,04 & 0,37 & 0,52 & 0,43 & 0,86 & 1,54 & 2,43 & 1,98 & 0,36 & 0,27 & 1,30 \\
\hline $\mathrm{Al}_{2} \mathrm{O}_{3}$ & 14,93 & 13,09 & 18,04 & 15,68 & 17,55 & 17,01 & 20,29 & 13,73 & 8,33 & 9,88 & 12,32 & 13,03 & 8,49 & 7,24 & 10,63 & 17,63 & 9,58 \\
\hline $\mathrm{Y}_{2} \mathrm{O}_{3}$ & 0,19 & 0,31 & 0,07 & 0,07 & 0,12 & 2,47 & 1,28 & 1,60 & 0,78 & 0,65 & 0,75 & 0,37 & 0,64 & 0,51 & 0,02 & 0,15 & 0,00 \\
\hline $\mathrm{FeO}$ & 13,27 & 14,97 & 11,28 & 11,84 & 10,79 & 12,16 & 9,62 & 15,64 & 21,04 & 19,67 & 16,98 & 14,18 & 7,02 & 17,72 & 17,85 & 13,78 & 19,93 \\
\hline MnO & 0,38 & 0,58 & 0,41 & 0,70 & 0,40 & 0,79 & 0,33 & 0,39 & 0,47 & 0,36 & 0,38 & 0,13 & 0,08 & 1,02 & 0,32 & 0,27 & 0,61 \\
\hline $\mathrm{CaO}$ & 11,74 & 10,20 & 12,30 & 9,30 & 12,56 & 10,47 & 15,39 & 11,16 & 9,17 & 9,21 & 10,80 & 11,23 & 6,01 & 7,96 & 11,57 & 16,89 & 12,50 \\
\hline $\mathbf{F}$ & 0,64 & 0,18 & 0,24 & 0,38 & 0,18 & 0,10 & 0,41 & 0,22 & 0,35 & 0,49 & 0,30 & 0,18 & 2,26 & 0,28 & 0,26 & 0,13 & 0,15 \\
\hline $\mathrm{La}_{2} \mathrm{O}_{3}$ & 4,11 & 5,54 & 3,11 & 3,64 & 2,53 & 2,23 & 1,89 & 3,66 & 5,24 & 4,85 & 3,79 & 3,96 & 5,57 & 9,38 & 4,90 & 1,99 & 7,18 \\
\hline $\mathrm{Ce}_{2} \mathrm{O}_{3}$ & 13,91 & 17,35 & 9,98 & 12,87 & 8,84 & 9,80 & 5,17 & 13,04 & 16,26 & 17,94 & 14,09 & 14,81 & 20,19 & 16,51 & 11,96 & 5,95 & 14,69 \\
\hline $\mathrm{Pr}_{2} \mathrm{O}_{3}$ & 0,86 & 1,11 & 0,67 & 0,82 & 0,70 & 0,74 & 0,29 & 0,96 & 1,17 & 1,24 & 1,03 & 0,81 & 1,09 & 0,49 & 0,42 & 0,29 & 0,35 \\
\hline $\mathrm{Nd}_{2} \mathrm{O}_{3}$ & 2,18 & 3,95 & 2,29 & 3,00 & 2,41 & 3,75 & 1,26 & 3,75 & 3,90 & 4,32 & 4,02 & 3,32 & 4,01 & 0,80 & 0,75 & 0,70 & 0,59 \\
\hline $\mathrm{Sm}_{2} \mathrm{O}_{3}$ & 0,15 & 0,51 & 0,32 & 0,48 & 0,32 & 0,82 & 0,26 & 0,82 & 0,64 & 0,61 & 0,56 & 0,49 & 0,51 & 0,00 & 0,05 & 0,12 & 0,03 \\
\hline $\mathrm{Eu}_{2} \mathrm{O}_{3}$ & 0,14 & 0,23 & 0,12 & 0,10 & 0,22 & 0,25 & 0,28 & 0,22 & 0,17 & 0,27 & 0,12 & 0,15 & 0,18 & 0,07 & 0,07 & 0,03 & 0,07 \\
\hline $\mathrm{Gd}_{2} \mathrm{O}_{3}$ & 0,00 & 0,00 & 0,05 & 0,00 & 0,04 & 0,72 & 0,21 & 0,38 & 0,00 & 0,00 & 0,21 & 0,15 & 0,29 & 0,00 & 0,06 & 0,00 & 0,00 \\
\hline $\mathrm{Tb}_{2} \mathrm{O}_{3}$ & 0,00 & 0,00 & 0,00 & 0,00 & 0,00 & 0,00 & 0,00 & 0,00 & 0,00 & 0,00 & 0,00 & 0,00 & 0,00 & 0,00 & 0,00 & 0,00 & 0,00 \\
\hline $\mathrm{Dy}_{2} \mathrm{O}_{3}$ & 0,00 & 0,00 & 0,00 & 0,00 & 0,00 & 0,86 & 0,34 & 0,20 & 0,00 & 0,00 & 0,00 & 0,00 & 0,00 & 0,00 & 0,00 & 0,00 & 0,00 \\
\hline $\mathrm{Ho}_{2} \mathrm{O}_{3}$ & 0,11 & 0,12 & 0,06 & 0,12 & 0,05 & 0,24 & 0,15 & 0,20 & 0,00 & 0,16 & 0,02 & 0,00 & 0,00 & 0,00 & 0,16 & 0,19 & 0,00 \\
\hline $\mathrm{Er}_{2} \mathrm{O}_{3}$ & 0,08 & 0,10 & 0,07 & 0,07 & 0,00 & 0,24 & 0,32 & 0,19 & 0,11 & 0,16 & 0,17 & 0,01 & 0,14 & 0,10 & 0,04 & 0,04 & 0,15 \\
\hline $\mathrm{Tm}_{2} \mathrm{O}_{3}$ & 0,03 & 0,00 & 0,00 & 0,01 & 0,00 & 0,05 & 0,09 & 0,00 & 0,00 & 0,00 & 0,01 & 0,00 & 0,00 & 0,03 & 0,00 & 0,00 & 0,00 \\
\hline $\mathrm{Yb}_{2} \mathrm{O}_{3}$ & 0,00 & 0,00 & 0,02 & 0,05 & 0,02 & 0,09 & 0,17 & 0,08 & 0,19 & 0,07 & 0,12 & 0,02 & 0,00 & 0,06 & 0,00 & 0,03 & 0,06 \\
\hline $\mathrm{Lu}_{2} \mathrm{O}_{3}$ & 0,00 & 0,08 & 0,01 & 0,03 & 0,00 & 0,00 & 0,07 & 0,06 & 0,00 & 0,00 & 0,00 & 0,06 & 0,00 & 0,06 & 0,00 & 0,00 & 0,07 \\
\hline $\mathrm{F}=\mathrm{O}_{2}$ & 0,27 & 0,08 & 0,10 & 0,16 & 0,08 & 0,04 & 0,17 & 0,09 & 0,15 & 0,21 & 0,13 & 0,08 & 0,95 & 0,12 & 0,11 & 0,05 & 0,06 \\
\hline Total & 95,42 & 98,23 & 91,59 & 91,62 & 91,04 & 95,68 & 93,85 & 96,58 & 95,20 & 97,63 & 95,26 & 94,35 & 86,70 & 90,68 & 88,57 & 92,17 & 97,37 \\
\hline$R E E+Y$ & 21,74 & 29,29 & 16,76 & 21,25 & 15,23 & 22,26 & 11,77 & 25,16 & 28,47 & 30,27 & 24,87 & 24,15 & 32,62 & 28,02 & 18,43 & 9,48 & 23,18 \\
\hline LREE & 21,33 & 28,70 & 16,48 & 20,91 & 15,01 & 17,59 & 9,15 & 22,45 & 27,38 & 29,23 & 23,60 & 23,53 & 31,55 & 27,25 & 18,14 & 9,07 & 22,91 \\
\hline HREE $+Y$ & 0,41 & 0,60 & 0,27 & 0,34 & 0,23 & 4,67 & 2,62 & 2,71 & 1,09 & 1,05 & 1,27 & 0,61 & 1,07 & 0,76 & 0,28 & 0,41 & 0,28 \\
\hline Fórmula & estructura & calculad & com bas & em 12, & oxigênio & & & & & & & & & & & & \\
\hline $\mathbf{P}$ & 0,011 & 0,003 & 0,127 & 0,159 & 0,122 & 0,055 & 0,084 & 0,000 & 0,010 & 0,009 & 0,001 & 0,008 & 0,004 & 0,000 & 0,002 & 0,000 & 0,001 \\
\hline Si & 3,030 & 2,973 & 2,939 & 2,916 & 2,940 & 2,984 & 3,035 & 2,980 & 2,964 & 2,927 & 2,975 & 3,029 & 3,264 & 2,984 & 3,148 & 3,114 & 3,040 \\
\hline $\mathrm{Zr}$ & 0,000 & 0,000 & 0,000 & 0,000 & 0,000 & 0,000 & 0,000 & 0,000 & 0,000 & 0,000 & 0,000 & 0,000 & 0,000 & 0,000 & 0,000 & 0,000 & 0,000 \\
\hline $\mathrm{Ti}$ & 0,245 & 0,079 & 0,063 & 0,100 & 0,043 & 0,054 & 0,006 & 0,056 & 0,087 & 0,069 & 0,134 & 0,237 & 0,438 & 0,346 & 0,058 & 0,038 & 0,200 \\
\hline Al & 1,733 & 1,575 & 2,065 & 1,884 & 2,034 & 1,949 & 2,186 & 1,635 & 1,087 & 1,253 & 1,507 & 1,568 & 1,199 & 0,992 & 1,358 & 1,946 & 1,159 \\
\hline $\mathbf{Y}$ & 0,005 & 0,008 & 0,002 & 0,002 & 0,003 & 0,064 & 0,031 & 0,043 & 0,023 & 0,019 & 0,021 & 0,010 & 0,020 & 0,016 & 0,001 & 0,004 & 0,000 \\
\hline $\mathrm{Fe}$ & 1,093 & 1,278 & 0,917 & 1,009 & 0,887 & 0,989 & 0,735 & 1,322 & 1,948 & 1,770 & 1,474 & 1,212 & 0,704 & 1,722 & 1,619 & 1,080 & 1,711 \\
\hline Mn & 0,031 & 0,050 & 0,034 & 0,060 & 0,033 & 0,065 & 0,026 & 0,034 & 0,044 & 0,033 & 0,033 & 0,011 & 0,008 & 0,100 & 0,029 & 0,022 & 0,053 \\
\hline $\mathrm{Ca}$ & 1,239 & 1,116 & 1,281 & 1,016 & 1,323 & 1,091 & 1,508 & 1,208 & 1,087 & 1,061 & 1,201 & 1,229 & 0,772 & 0,992 & 1,345 & 1,695 & 1,375 \\
\hline $\mathbf{F}$ & 0,199 & 0,058 & 0,074 & 0,123 & 0,057 & 0,030 & 0,119 & 0,070 & 0,122 & 0,168 & 0,097 & 0,058 & 0,855 & 0,101 & 0,091 & 0,039 & 0,047 \\
\hline La & 0,149 & 0,209 & 0,111 & 0,137 & 0,092 & 0,080 & 0,064 & 0,136 & 0,214 & 0,192 & 0,145 & 0,149 & 0,246 & 0,402 & 0,196 & 0,069 & 0,272 \\
\hline $\mathrm{Ce}$ & 0,501 & 0,648 & 0,355 & 0,480 & 0,318 & 0,349 & 0,173 & 0,482 & 0,659 & 0,707 & 0,536 & 0,554 & 0,886 & 0,703 & 0,475 & 0,204 & 0,552 \\
\hline $\mathrm{Pr}$ & 0,031 & 0,041 & 0,024 & 0,031 & 0,025 & 0,026 & 0,010 & 0,035 & 0,047 & 0,049 & 0,039 & 0,030 & 0,048 & 0,021 & 0,017 & 0,010 & 0,013 \\
\hline Nd & 0,077 & 0,144 & 0,079 & 0,109 & 0,085 & 0,130 & 0,041 & 0,135 & 0,154 & 0,166 & 0,149 & 0,121 & 0,172 & 0,033 & 0,029 & 0,024 & 0,022 \\
\hline Sm & 0,005 & 0,018 & 0,011 & 0,017 & 0,011 & 0,027 & 0,008 & 0,028 & 0,024 & 0,023 & 0,020 & 0,017 & 0,021 & 0,000 & 0,002 & 0,004 & 0,001 \\
\hline Eu & 0,005 & 0,008 & 0,004 & 0,004 & 0,007 & 0,008 & 0,009 & 0,008 & 0,007 & 0,010 & 0,004 & 0,005 & 0,007 & 0,003 & 0,003 & 0,001 & 0,002 \\
\hline Gd & 0,000 & 0,000 & 0,002 & 0,000 & 0,001 & 0,023 & 0,006 & 0,013 & 0,000 & 0,000 & 0,007 & 0,005 & 0,011 & 0,000 & 0,002 & 0,000 & 0,000 \\
\hline Tb & 0,000 & 0,000 & 0,000 & 0,000 & 0,000 & 0,000 & 0,000 & 0,000 & 0,000 & 0,000 & 0,000 & 0,000 & 0,000 & 0,000 & 0,000 & 0,000 & 0,000 \\
\hline Dy & 0,000 & 0,000 & 0,000 & 0,000 & 0,000 & 0,027 & 0,010 & 0,007 & 0,000 & 0,000 & 0,000 & 0,000 & 0,000 & 0,000 & 0,000 & 0,000 & 0,000 \\
\hline Ho & 0,003 & 0,004 & 0,002 & 0,004 & 0,002 & 0,007 & 0,004 & 0,006 & 0,000 & 0,006 & 0,001 & 0,000 & 0,000 & 0,000 & 0,005 & 0,006 & 0,000 \\
\hline Er & 0,002 & 0,003 & 0,002 & 0,002 & 0,000 & 0,007 & 0,009 & 0,006 & 0,004 & 0,005 & 0,006 & 0,000 & 0,005 & 0,004 & 0,001 & 0,001 & 0,005 \\
\hline $\mathrm{Tm}$ & 0,001 & 0,000 & 0,000 & 0,000 & 0,000 & 0,002 & 0,003 & 0,000 & 0,000 & 0,000 & 0,000 & 0,000 & 0,000 & 0,001 & 0,000 & 0,000 & 0,000 \\
\hline $\mathrm{Yb}$ & 0,000 & 0,000 & 0,000 & 0,001 & 0,000 & 0,003 & 0,005 & 0,002 & 0,006 & 0,002 & 0,004 & 0,001 & 0,000 & 0,002 & 0,000 & 0,001 & 0,002 \\
\hline Lu & 0,000 & 0,002 & 0,000 & 0,001 & 0,000 & 0,000 & 0,002 & 0,002 & 0,000 & 0,000 & 0,000 & 0,002 & 0,000 & 0,002 & 0,000 & 0,000 & 0,002 \\
\hline Total & 8,380 & 8,235 & 8,111 & 8,132 & 8,187 & 8,026 & 8,132 & 8,288 & 8,499 & 8,475 & 8,361 & 8,259 & 8,730 & 8,481 & 8,394 & 8,286 & 8,490 \\
\hline
\end{tabular}




\subsection{QUÍMICA MINERAL PARA SS-TORITAS}

\begin{tabular}{|c|c|c|c|c|c|c|c|c|c|c|}
\hline & \multicolumn{2}{|c|}{ Thorite } & \multicolumn{8}{|c|}{ SS Thorita-Xenotime } \\
\hline & $\begin{array}{l}\text { 14AGord } \\
\text { os_h7.2 }\end{array}$ & $\begin{array}{l}\text { 14AGord } \\
\text { os_h7.3 }\end{array}$ & $\begin{array}{l}\text { AZME12B } \\
\text { 5D_A8 } 1\end{array}$ & $\begin{array}{l}\text { AZME12B } \\
\text { 5D_A8 } 2\end{array}$ & $\begin{array}{l}\text { ME10C- } \\
\text { 1torita }\end{array}$ & $\begin{array}{l}\text { ME- } \\
10 \mathrm{C} \_ \text {of_c } \\
5 \quad 2\end{array}$ & $\begin{array}{l}\text { ME- } \\
10 \mathrm{C} \text {-of_c } \\
5 \quad 3\end{array}$ & $\begin{array}{l}\text { ME- } \\
10 \mathrm{C} \_ \text {of_c } \\
6 \quad 3\end{array}$ & $\begin{array}{l}\text { ME- } \\
10 \mathrm{C} \text { of_c } \\
6 \quad 4\end{array}$ & $\begin{array}{l}\text { ME- } \\
10 \mathrm{C} \text { _of_f } \\
\text { orac3 }\end{array}$ \\
\hline $\mathrm{P}_{2} \mathrm{O}_{5}$ & 1,92 & 0,83 & 5,45 & 5,34 & 0,44 & 4,14 & 4,86 & 3,81 & 4,27 & 4,83 \\
\hline $\mathrm{Nb}_{2} \mathrm{O}_{5}$ & 1,47 & 0,00 & 0,00 & 0,00 & 0,48 & 0,29 & 0,58 & 0,11 & 0,12 & 0,39 \\
\hline $\mathrm{SiO}_{2}$ & 13,54 & 11,38 & 11,26 & 11,58 & 12,29 & 11,23 & 10,38 & 12,19 & 12,86 & 11,69 \\
\hline $\mathrm{ZrO}_{2}$ & 6,53 & 0,00 & 0,97 & 1,05 & 0,00 & 0,76 & 1,27 & 0,14 & 0,09 & 0,09 \\
\hline $\mathrm{TiO}_{2}$ & 0,00 & 0,00 & 0,27 & 0,07 & 0,13 & 0,00 & 0,21 & 0,00 & 0,05 & 0,00 \\
\hline $\mathrm{Al}_{2} \mathrm{O}_{3}$ & 1,08 & 0,16 & 0,22 & 0,25 & 0,22 & 0,58 & 0,58 & 0,50 & 0,52 & 0,37 \\
\hline $\mathrm{Y}_{2} \mathrm{O}_{3}$ & 4,96 & 2,13 & 7,23 & 6,91 & 11,76 & 12,65 & 11,96 & 8,35 & 4,72 & 7,44 \\
\hline $\mathrm{FeO}$ & 4,62 & 0,55 & 1,72 & 1,87 & 1,49 & 1,41 & 1,76 & 0,68 & 1,02 & 1,18 \\
\hline $\mathrm{CaO}$ & 0,13 & 0,50 & 0,94 & 1,14 & 0,84 & 1,98 & 2,14 & 1,83 & 1,86 & 2,27 \\
\hline $\mathrm{La}_{2} \mathrm{O}_{3}$ & 0,10 & 0,02 & 0,09 & 0,14 & 0,16 & 0,06 & 0,10 & 0,13 & 0,64 & 0,24 \\
\hline $\mathrm{Ce}_{2} \mathrm{O}_{3}$ & 1,27 & 0,11 & 2,51 & 2,32 & 8,16 & 2,35 & 2,17 & 2,32 & 0,48 & 3,18 \\
\hline $\mathrm{Pr}_{2} \mathrm{O}_{3}$ & 0,00 & 0,00 & 0,25 & 0,17 & 0,09 & 0,07 & 0,17 & 0,08 & 0,19 & 0,34 \\
\hline $\mathrm{Nd}_{2} \mathrm{O}_{3}$ & 0,35 & 0,06 & 0,99 & 0,94 & 0,56 & 0,43 & 0,78 & 0,70 & 0,87 & 1,44 \\
\hline $\mathrm{Sm}_{2} \mathrm{O}_{3}$ & 0,00 & 0,00 & 0,49 & 0,52 & 0,23 & 0,35 & 0,36 & 0,14 & 0,25 & 0,43 \\
\hline $\mathrm{Eu}_{2} \mathrm{O}_{3}$ & 0,00 & 0,04 & 0,07 & 0,08 & 0,09 & 0,00 & 0,00 & 0,02 & 0,00 & 0,00 \\
\hline $\mathrm{Gd}_{2} \mathrm{O}_{3}$ & 0,39 & 0,15 & 0,87 & 0,80 & 0,53 & 0,45 & 0,81 & 0,44 & 0,19 & 0,63 \\
\hline $\mathrm{Tb}_{2} \mathrm{O}_{3}$ & 0,00 & 0,00 & 0,00 & 0,00 & 0,00 & 0,07 & 0,17 & 0,15 & 0,00 & 0,09 \\
\hline $\mathrm{Dy}_{2} \mathrm{O}_{3}$ & 0,23 & 0,33 & 1,22 & 1,27 & 1,80 & 1,28 & 1,80 & 1,07 & 0,34 & 1,34 \\
\hline $\mathrm{Ho}_{2} \mathrm{O}_{3}$ & 0,28 & 0,25 & 0,20 & 0,18 & 0,68 & 0,45 & 0,64 & 0,13 & 0,15 & 0,15 \\
\hline $\mathrm{Er}_{2} \mathrm{O}_{3}$ & 0,63 & 0,20 & 0,85 & 0,77 & 2,23 & 1,49 & 1,95 & 1,16 & 0,53 & 1,21 \\
\hline $\mathrm{Tm}_{2} \mathrm{O}_{3}$ & 0,08 & 0,00 & 0,06 & 0,13 & 0,42 & 0,30 & 0,31 & 0,16 & 0,09 & 0,11 \\
\hline $\mathrm{Yb}_{2} \mathrm{O}_{3}$ & 0,88 & 0,24 & 0,56 & 0,64 & 3,74 & 2,63 & 3,01 & 1,56 & 0,47 & 1,70 \\
\hline $\mathrm{Lu}_{2} \mathrm{O}_{3}$ & 0,15 & 0,00 & 0,04 & 0,25 & 0,67 & 0,46 & 0,67 & 0,32 & 0,12 & 0,30 \\
\hline $\mathrm{UO}_{2}$ & 4,81 & 8,43 & 1,16 & 1,09 & 0,72 & 0,65 & 1,12 & 0,81 & 1,81 & 2,54 \\
\hline $\mathrm{ThO}_{2}$ & 53,54 & 63,61 & 47,13 & 46,08 & 31,64 & 27,97 & 39,92 & 46,14 & 54,93 & 43,30 \\
\hline $\mathbf{F}$ & 1,14 & 1,46 & 0,81 & 0,79 & 1,43 & 1,67 & 1,73 & 1,67 & 1,48 & 1,68 \\
\hline $\mathrm{F}=\mathrm{O}_{2}$ & 0,48 & 0,62 & 0,34 & 0,33 & & 0,70 & 0,73 & 0,70 & 0,62 & 0,71 \\
\hline Total & 97,65 & 89,84 & 85,15 & 84,29 & 80,49 & 73,25 & 88,96 & 83,98 & 87,58 & 86,26 \\
\hline REE $+Y$ & 9,33 & 3,52 & 15,42 & 15,11 & 31,10 & 23,03 & 24,89 & 16,73 & 9,06 & 18,59 \\
\hline LREE & 1,72 & 0,23 & 4,41 & 4,17 & 9,30 & 3,24 & 3,59 & 3,39 & 2,44 & 5,63 \\
\hline HREE+Y & 7,60 & 3,29 & 11,02 & 10,95 & 21,81 & 19,78 & 21,30 & 13,34 & 6,62 & 12,96 \\
\hline \multicolumn{11}{|c|}{ Formula estructural calculada com base em 16 oxigênios } \\
\hline $\mathbf{P}$ & 0,334 & 0,185 & 1,050 & 1,031 & 0,095 & 0,863 & 0,905 & 0,755 & 0,818 & 0,926 \\
\hline Nb & 0,137 & 0,000 & 0,000 & 0,000 & 0,055 & 0,033 & 0,057 & 0,011 & 0,012 & 0,040 \\
\hline Si & 2,787 & 2,990 & 2,564 & 2,642 & 3,125 & 2,765 & 2,282 & 2,851 & 2,911 & 2,646 \\
\hline $\mathrm{Zr}$ & 0,655 & 0,000 & 0,108 & 0,117 & 0,000 & 0,091 & 0,136 & 0,016 & 0,010 & 0,010 \\
\hline $\mathrm{Ti}$ & 0,000 & 0,000 & 0,093 & 0,025 & 0,049 & 0,000 & 0,070 & 0,000 & 0,015 & 0,000 \\
\hline Al & 0,261 & 0,051 & 0,060 & 0,067 & 0,065 & 0,169 & 0,151 & 0,139 & 0,139 & 0,099 \\
\hline $\mathbf{Y}$ & 0,271 & 0,149 & 0,438 & 0,420 & 0,795 & 0,829 & 0,700 & 0,519 & 0,284 & 0,448 \\
\hline $\mathrm{Fe}$ & 0,796 & 0,122 & 0,328 & 0,356 & 0,316 & 0,290 & 0,324 & 0,132 & 0,192 & 0,224 \\
\hline $\mathrm{Ca}$ & 0,028 & 0,142 & 0,229 & 0,279 & 0,228 & 0,522 & 0,503 & 0,460 & 0,451 & 0,551 \\
\hline La & 0,008 & 0,002 & 0,007 & 0,012 & 0,015 & 0,005 & 0,008 & 0,011 & 0,054 & 0,020 \\
\hline $\mathrm{Ce}$ & 0,096 & 0,010 & 0,210 & 0,194 & 0,759 & 0,211 & 0,175 & 0,199 & 0,040 & 0,263 \\
\hline Pr & 0,000 & 0,000 & 0,021 & 0,014 & 0,009 & 0,006 & 0,014 & 0,007 & 0,016 & 0,028 \\
\hline Nd & 0,025 & 0,006 & 0,081 & 0,077 & 0,051 & 0,037 & 0,061 & 0,058 & 0,070 & 0,116 \\
\hline Sm & 0,000 & 0,000 & 0,038 & 0,041 & 0,020 & 0,029 & 0,028 & 0,012 & 0,020 & 0,033 \\
\hline $\mathrm{Eu}$ & 0,000 & 0,003 & 0,006 & 0,006 & 0,008 & 0,000 & 0,000 & 0,001 & 0,000 & 0,000 \\
\hline Gd & 0,027 & 0,013 & 0,066 & 0,060 & 0,044 & 0,036 & 0,059 & 0,034 & 0,014 & 0,047 \\
\hline Tb & 0,000 & 0,000 & 0,000 & 0,000 & 0,000 & 0,005 & 0,012 & 0,012 & 0,000 & 0,007 \\
\hline Dy & 0,015 & 0,028 & 0,089 & 0,093 & 0,147 & 0,102 & 0,128 & 0,081 & 0,025 & 0,098 \\
\hline Ho & 0,018 & 0,021 & 0,014 & 0,013 & 0,055 & 0,036 & 0,045 & 0,010 & 0,011 & 0,011 \\
\hline $\mathrm{Er}$ & 0,041 & 0,017 & 0,061 & 0,055 & 0,178 & 0,115 & 0,135 & 0,085 & 0,038 & 0,086 \\
\hline $\mathrm{Tm}$ & 0,005 & 0,000 & 0,004 & 0,009 & 0,033 & 0,023 & 0,021 & 0,012 & 0,006 & 0,008 \\
\hline $\mathrm{Yb}$ & 0,055 & 0,019 & 0,039 & 0,045 & 0,290 & 0,198 & 0,202 & 0,111 & 0,033 & 0,117 \\
\hline Lu & 0,009 & 0,000 & 0,002 & 0,017 & 0,051 & 0,034 & 0,044 & 0,022 & 0,008 & 0,021 \\
\hline $\mathbf{U}$ & 0,220 & 0,493 & 0,059 & 0,055 & 0,041 & 0,036 & 0,055 & 0,042 & 0,091 & 0,128 \\
\hline Th & 2,507 & 3,803 & 2,443 & 2,393 & 1,830 & 1,567 & 1,997 & 2,456 & 2,829 & 2,231 \\
\hline Total & 8,301 & 8,055 & 8,026 & 8,039 & 8,323 & 8,028 & 8,134 & 8,050 & 8,110 & 8,163 \\
\hline Thor & 65,709 & 94,434 & 62,342 & 60,902 & 44,968 & 39,919 & 50,458 & 62,074 & 72,005 & 57,793 \\
\hline Xen & 8,049 & 4,590 & 26,162 & 25,649 & 2,291 & 21,506 & 22,263 & 18,765 & 20,168 & 22,694 \\
\hline Total & 73,758 & 99,024 & 88,504 & 86,551 & 47,259 & 61,425 & 72,721 & 80,839 & 92,172 & 80,487 \\
\hline
\end{tabular}


CONTINUAÇÃO- SS TORITAS

SS Thorita-Xenotima

\begin{tabular}{|c|c|c|c|c|c|c|c|c|c|c|c|c|}
\hline & $\begin{array}{l}\text { ME- } \\
10 \mathrm{C} \_ \text {of_f } \\
\text { orac3 }\end{array}$ & $\begin{array}{l}\text { AZME-8- } \\
\text { C_C1.6pe } \\
\text { rto }\end{array}$ & $\begin{array}{l}\text { AZME-8- } \\
\text { C_C1.6pe } \\
\text { rto }\end{array}$ & $\begin{array}{l}\text { AZME-4- } \\
\text { A_C } \\
\text { af.pertoC }\end{array}$ & $\begin{array}{l}\text { AZME-4- } \\
\text { A_C } \\
\text { af.pertoC }\end{array}$ & $\begin{array}{l}\text { AZME-4- } \\
\text { A_C } \\
\text { af.pertoC }\end{array}$ & $\begin{array}{l}\text { AZME- } \\
\text { 09A- } \\
\text { C1.3.02 } \\
\end{array}$ & $\begin{array}{l}\text { AZME- } \\
09 A-C 5.2\end{array}$ & $\begin{array}{l}\text { AZME7D_ } \\
\text { C4 } 1.1\end{array}$ & $\begin{array}{l}\text { AZME7D_ } \\
\text { C4 } 1.2\end{array}$ & $\begin{array}{l}\text { AZME4A_ } \\
\text { C7 } 1.1\end{array}$ & $\begin{array}{l}\text { AZME4A } \\
\text { C7 } 1.2\end{array}$ \\
\hline $\mathbf{P}_{2} \mathbf{O}_{5}$ & 4,52 & 3,25 & 2,71 & 8,70 & 8,13 & 6,98 & 5,60 & 5,03 & 2,87 & 2,90 & 5,53 & 8,86 \\
\hline $\mathrm{Nb}_{2} \mathrm{O}_{5}$ & 0,33 & 0,00 & 0,00 & 0,15 & 0,14 & 0,27 & 0,00 & 0,09 & 0,00 & 0,00 & 0,61 & 0,61 \\
\hline $\mathrm{SiO}_{2}$ & 11,01 & 16,10 & 13,35 & 10,44 & 9,08 & 10,18 & 13,44 & 13,50 & 14,67 & 12,99 & 7,67 & 9,31 \\
\hline $\mathrm{ZrO}_{2}$ & 0,07 & 5,59 & 0,91 & 8,02 & 5,41 & 1,51 & 0,16 & 0,00 & 2,61 & 0,39 & 4,02 & 6,04 \\
\hline $\mathrm{TiO}_{2}$ & 0,00 & 0,45 & 0,18 & 0,23 & 0,06 & 0,06 & 0,00 & 0,12 & 0,17 & 0,08 & 0,00 & 0,40 \\
\hline $\mathrm{Al}_{2} \mathrm{O}_{3}$ & 0,44 & 1,93 & 0,68 & 3,92 & 2,71 & 1,84 & 0,94 & 0,96 & 0,45 & 0,29 & 2,02 & 4,18 \\
\hline $\mathrm{Y}_{2} \mathrm{O}_{3}$ & 7,38 & 6,80 & 6,57 & 5,45 & 5,70 & 6,50 & 11,09 & 9,74 & 8,03 & 8,16 & 7,95 & 5,74 \\
\hline $\mathrm{FeO}$ & 0,41 & 2,46 & 0,59 & 1,25 & 0,54 & 2,05 & 2,73 & 4,39 & 1,20 & 0,47 & 0,92 & 0,83 \\
\hline $\mathrm{CaO}$ & 1,96 & 0,62 & 1,32 & 0,46 & 0,54 & 0,12 & 0,00 & 0,53 & 0,67 & 0,69 & 0,14 & 0,00 \\
\hline $\mathrm{La}_{2} \mathrm{O}_{3}$ & 0,29 & 0,28 & 0,33 & 0,00 & 0,00 & 0,00 & 0,23 & 0,11 & 0,15 & 0,11 & 0,00 & 0,09 \\
\hline $\mathrm{Ce}_{2} \mathrm{O}_{3}$ & 1,67 & 5,28 & 5,45 & 0,95 & 0,29 & 0,42 & 7,76 & 2,94 & 2,37 & 2,47 & 0,49 & 0,77 \\
\hline $\mathrm{Pr}_{2} \mathrm{O}_{3}$ & 0,25 & 0,29 & 0,27 & 0,02 & 0,00 & 0,08 & 0,18 & 0,13 & 0,09 & 0,14 & 0,00 & 0,00 \\
\hline $\mathrm{Nd}_{2} \mathrm{O}_{3}$ & 0,90 & 1,93 & 1,69 & 0,15 & 0,10 & 0,12 & 1,04 & 0,79 & 0,86 & 0,94 & 0,01 & 0,09 \\
\hline $\mathrm{Sm}_{2} \mathrm{O}_{3}$ & 0,40 & 0,84 & 0,77 & 0,20 & 0,09 & 0,07 & 0,40 & 0,26 & 0,40 & 0,40 & 0,14 & 0,08 \\
\hline $\mathrm{Eu}_{2} \mathrm{O}_{3}$ & 0,00 & 0,05 & 0,11 & 0,00 & 0,02 & 0,04 & 0,05 & 0,02 & 0,06 & 0,08 & 0,03 & 0,00 \\
\hline $\mathrm{Gd}_{2} \mathrm{O}_{3}$ & 0,54 & 1,18 & 1,28 & 0,29 & 0,18 & 0,29 & 1,26 & 0,87 & 0,87 & 1,06 & 0,24 & 0,23 \\
\hline $\mathrm{Tb}_{2} \mathrm{O}_{3}$ & 0,12 & 0,00 & 0,00 & 0,00 & 0,00 & 0,00 & 0,00 & 0,00 & 0,00 & 0,00 & 0,00 & 0,00 \\
\hline $\mathrm{Dy}_{2} \mathrm{O}_{3}$ & 1,05 & 1,13 & 1,25 & 0,94 & 1,03 & 1,08 & 1,50 & 1,77 & 1,40 & 1,65 & 1,40 & 0,78 \\
\hline $\mathrm{Ho}_{2} \mathrm{O}_{3}$ & 0,48 & 0,00 & 0,02 & 0,00 & 0,33 & 0,61 & 0,27 & 0,44 & 0,44 & 0,35 & 0,30 & 0,28 \\
\hline $\mathrm{Er}_{2} \mathrm{O}_{3}$ & 1,07 & 0,52 & 0,52 & 0,80 & 1,07 & 1,10 & 1,02 & 0,84 & 0,81 & 0,90 & 1,18 & 0,85 \\
\hline $\mathrm{Tm}_{2} \mathrm{O}_{3}$ & 0,19 & 0,00 & 0,17 & 0,13 & 0,11 & 0,16 & 0,09 & 0,16 & 0,03 & 0,19 & 0,13 & 0,11 \\
\hline $\mathrm{Yb}_{2} \mathrm{O}_{3}$ & 1,60 & 0,30 & 0,27 & 1,15 & 1,38 & 1,13 & 0,59 & 0,68 & 0,65 & 0,76 & 1,50 & 1,08 \\
\hline $\mathrm{Lu}_{2} \mathrm{O}_{3}$ & 0,31 & 0,09 & 0,14 & 0,19 & 0,31 & 0,20 & 0,12 & 0,11 & 0,25 & 0,28 & 0,30 & 0,22 \\
\hline $\mathrm{UO}_{2}$ & 1,40 & 3,62 & 5,70 & 2,31 & 1,80 & 1,46 & 0,69 & 0,61 & 1,64 & 2,60 & 0,98 & 1,05 \\
\hline $\mathrm{ThO}_{2}$ & 48,42 & 37,91 & 38,14 & 43,36 & 43,20 & 48,03 & 40,54 & 42,85 & 47,15 & 48,84 & 38,78 & 36,17 \\
\hline $\mathbf{F}$ & 1,93 & 0,96 & 1,12 & 1,83 & 1,63 & 1,79 & 1,00 & 1,21 & 1,96 & 2,66 & 1,52 & 1,62 \\
\hline $\mathrm{F}=\mathrm{O}_{2}$ & 0,81 & 0,40 & 0,47 & 0,77 & 0,69 & 0,75 & 0,42 & 0,51 & 0,82 & 1,12 & 0,64 & 0,68 \\
\hline Total & 85,98 & 91,23 & 83,14 & 90,28 & 83,14 & 85,38 & 90,29 & 88,07 & 88,97 & 88,42 & 75,38 & 79,21 \\
\hline$R E E+Y$ & 16,25 & 18,68 & 18,84 & 10,28 & 10,60 & 11,81 & 25,59 & 18,86 & 16,41 & 17,48 & 13,66 & 10,32 \\
\hline LREE & 3,51 & 8,66 & 8,62 & 1,33 & 0,50 & 0,72 & 6 & 4,25 & 3,93 & 4,14 & 0,67 & 1,02 \\
\hline HREE+Y & 12,74 & 10,01 & 10,21 & 8,95 & 10,09 & 11,08 & 15,94 & 14,61 & 12,48 & 13,34 & 12,99 & 9,29 \\
\hline \multicolumn{13}{|c|}{ Formula estructural calculada com base em 16 oxigênios } \\
\hline $\mathbf{P}$ & 0,898 & 0,537 & 0,537 & 1,409 & 1,487 & 1,307 & 0,972 & 0,893 & 0,529 & 0,569 & 1,181 & 1,566 \\
\hline Nb & 0,035 & 0,000 & 0,000 & 0,013 & 0,014 & 0,027 & 0,000 & 0,008 & 0,000 & 0,000 & 0,069 & 0,058 \\
\hline Si & 2,580 & 3,144 & 3,126 & 1,997 & 1,963 & 2,251 & 2,756 & 2,830 & 3,190 & 3,012 & 1,936 & 1,942 \\
\hline $\mathrm{Zr}$ & 0,007 & 0,532 & 0,104 & 0,748 & 0,570 & 0,162 & 0,016 & 0,000 & 0,277 & 0,044 & 0,494 & 0,614 \\
\hline $\mathrm{Ti}$ & 0,000 & 0,131 & 0,063 & 0,065 & 0,018 & 0,020 & 0,000 & 0,036 & 0,055 & 0,027 & 0,000 & 0,127 \\
\hline Al & 0,122 & 0,444 & 0,188 & 0,883 & 0,690 & 0,480 & 0,227 & 0,236 & 0,115 & 0,078 & 0,602 & 1,029 \\
\hline $\mathbf{Y}$ & 0,460 & 0,353 & 0,409 & 0,277 & 0,328 & 0,383 & 0,605 & 0,543 & 0,464 & 0,503 & 0,534 & 0,319 \\
\hline $\mathrm{Fe}$ & 0,081 & 0,401 & 0,116 & 0,201 & 0,097 & 0,379 & 0,468 & 0,770 & 0,218 & 0,091 & 0,193 & 0,146 \\
\hline $\mathrm{Ca}$ & 0,493 & 0,130 & 0,331 & 0,095 & 0,124 & 0,028 & 0,000 & 0,120 & 0,157 & 0,171 & 0,039 & 0,000 \\
\hline $\mathrm{La}$ & 0,025 & 0,020 & 0,029 & 0,000 & 0,000 & 0,000 & 0,017 & 0,008 & 0,012 & 0,009 & 0,000 & 0,007 \\
\hline $\mathrm{Ce}$ & 0,143 & 0,378 & 0,467 & 0,067 & 0,023 & 0,034 & 0,582 & 0,226 & 0,189 & 0,210 & 0,045 & 0,059 \\
\hline $\mathrm{Pr}$ & 0,021 & 0,021 & 0,023 & 0,001 & 0,000 & 0,006 & 0,014 & 0,010 & 0,007 & 0,012 & 0,000 & 0,000 \\
\hline Nd & 0,075 & 0,135 & 0,141 & 0,011 & 0,008 & 0,009 & 0,076 & 0,059 & 0,067 & 0,078 & 0,001 & 0,006 \\
\hline Sm & 0,032 & 0,056 & 0,062 & 0,013 & 0,007 & 0,005 & 0,028 & 0,019 & 0,030 & 0,032 & 0,012 & 0,006 \\
\hline Eu & 0,000 & 0,003 & 0,009 & 0,000 & 0,002 & 0,003 & 0,003 & 0,001 & 0,004 & 0,006 & 0,002 & 0,000 \\
\hline Gd & 0,042 & 0,076 & 0,099 & 0,018 & 0,013 & 0,021 & 0,086 & 0,061 & 0,063 & 0,081 & 0,020 & 0,016 \\
\hline $\mathrm{Tb}$ & 0,009 & 0,000 & 0,000 & 0,000 & 0,000 & 0,000 & 0,000 & 0,000 & 0,000 & 0,000 & 0,000 & 0,000 \\
\hline Dy & 0,079 & 0,071 & 0,094 & 0,058 & 0,072 & 0,077 & 0,099 & 0,119 & 0,098 & 0,123 & 0,113 & 0,053 \\
\hline Ho & 0,036 & 0,000 & 0,001 & 0,000 & 0,022 & 0,043 & 0,018 & 0,030 & 0,030 & 0,026 & 0,024 & 0,019 \\
\hline $\mathrm{Er}$ & 0,078 & 0,032 & 0,038 & 0,048 & 0,073 & 0,076 & 0,066 & 0,055 & 0,055 & 0,065 & 0,094 & 0,056 \\
\hline $\mathrm{Tm}$ & 0,014 & 0,000 & 0,013 & 0,008 & 0,007 & 0,011 & 0,006 & 0,010 & 0,002 & 0,014 & 0,010 & 0,007 \\
\hline $\mathrm{Yb}$ & 0,114 & 0,018 & 0,019 & 0,067 & 0,091 & 0,076 & 0,037 & 0,043 & 0,043 & 0,054 & 0,116 & 0,069 \\
\hline Lu & 0,022 & 0,006 & 0,010 & 0,011 & 0,020 & 0,013 & 0,007 & 0,007 & 0,016 & 0,020 & 0,023 & 0,014 \\
\hline $\mathbf{U}$ & 0,073 & 0,157 & 0,297 & 0,098 & 0,086 & 0,072 & 0,031 & 0,029 & 0,079 & 0,134 & 0,055 & 0,049 \\
\hline Th & 2,582 & 1,685 & 2,032 & 1,887 & 2,124 & 2,416 & 1,891 & 2,045 & 2,333 & 2,578 & 2,227 & 1,718 \\
\hline Total & 8,030 & 8,344 & 8,222 & 7,989 & 7,837 & 7,904 & 8,008 & 8,187 & 8,034 & 7,968 & 7,828 & 7,913 \\
\hline Thor & 66,140 & 44,150 & 56,643 & 49,698 & 56,408 & 62,959 & 48,007 & 50,654 & 60,050 & 68,070 & 58,292 & 44,662 \\
\hline Xen & 22,358 & 12,881 & 13,063 & 35,280 & 37,946 & 33,071 & 24,270 & 21,812 & 13,160 & 14,293 & 30,179 & 39,580 \\
\hline Total & 88,498 & 57,031 & 69,707 & 84,979 & 94,353 & 96,030 & 72,276 & 72,466 & 73,210 & 82,363 & 88,471 & 84,242 \\
\hline
\end{tabular}


CONTINUAÇÃO- SS TORITAS

\begin{tabular}{|c|c|c|c|c|c|c|c|c|c|c|}
\hline & \multicolumn{10}{|c|}{ SS Thorita-zircon } \\
\hline & $\begin{array}{l}\text { ME- } \\
10 \mathrm{C} \text { of_c } \\
23\end{array}$ & $\begin{array}{l}\text { AZME-4- } \\
\text { A_C5- } \\
\text { embaixo.0 }\end{array}$ & $\begin{array}{l}\text { AZME-4- } \\
\text { A_C5- } \\
\text { embaixo.0 }\end{array}$ & $\begin{array}{l}\text { AZME-4- } \\
\text { A_C5- } \\
\text { encima.01 }\end{array}$ & $\begin{array}{l}\text { AZME-4- } \\
\text { A_C } \\
\text { af.pertoC }\end{array}$ & $\begin{array}{l}\text { AZME-4- } \\
\text { A_C3fora } \\
.02\end{array}$ & $\begin{array}{l}\text { AZME-4- } \\
\text { A_C3fora } \\
.03\end{array}$ & $\begin{array}{l}\text { AZME- } \\
\text { 09A- } \\
\text { C4.1.02 } \\
\end{array}$ & ME8_C1 2 & $\begin{array}{l}\text { AZME4A } \\
\text { C7 } 2\end{array}$ \\
\hline $\mathrm{P}_{2} \mathrm{O}_{5}$ & 0,65 & 7,45 & 7,58 & 6,82 & 6,97 & 6,33 & 7,09 & 1,95 & 4,73 & 6,40 \\
\hline $\mathrm{Nb}_{2} \mathrm{O}_{5}$ & 0,57 & 0,82 & 1,15 & 0,63 & 1,24 & 0,83 & 1,04 & 0,70 & 0,32 & 0,62 \\
\hline $\mathrm{SiO}_{2}$ & 14,63 & 14,47 & 14,43 & 14,71 & 12,26 & 16,10 & 13,79 & 22,00 & 28,81 & 13,39 \\
\hline $\mathrm{ZrO}_{2}$ & 2,51 & 21,92 & 20,31 & 20,18 & 13,13 & 26,59 & 22,32 & 29,54 & 8,86 & 22,98 \\
\hline $\mathrm{TiO}_{2}$ & 0,12 & 0,17 & 0,23 & 0,50 & 0,00 & 0,23 & 0,25 & 0,27 & 0,03 & 0,21 \\
\hline $\mathrm{Al}_{2} \mathrm{O}_{3}$ & 1,09 & 4,46 & 4,64 & 4,49 & 3,35 & 3,62 & 4,60 & 3,85 & 1,00 & 2,84 \\
\hline $\mathrm{Y}_{2} \mathrm{O}_{3}$ & 10,49 & 6,29 & 6,79 & 7,21 & 9,68 & 6,21 & 6,17 & 6,43 & 12,38 & 6,49 \\
\hline $\mathrm{FeO}$ & 1,76 & 0,84 & 0,70 & 0,53 & 0,42 & 0,84 & 0,55 & 2,03 & 0,18 & 3,18 \\
\hline $\mathrm{CaO}$ & 0,91 & 0,43 & 0,11 & 0,23 & 0,00 & 0,07 & 0,00 & 0,51 & 0,43 & 0,31 \\
\hline $\mathrm{La}_{2} \mathrm{O}_{3}$ & 0,07 & 0,00 & 0,00 & 0,00 & 0,01 & 0,03 & 0,02 & 0,05 & 0,08 & 0,00 \\
\hline $\mathrm{Ce}_{2} \mathrm{O}_{3}$ & 3,50 & 0,37 & 0,36 & 0,33 & 0,38 & 0,26 & 0,25 & 2,14 & 1,87 & 0,20 \\
\hline $\mathrm{Pr}_{2} \mathrm{O}_{3}$ & 0,10 & 0,02 & 0,01 & 0,00 & 0,06 & 0,02 & 0,01 & 0,13 & 0,08 & 0,00 \\
\hline $\mathrm{Nd}_{2} \mathrm{O}_{3}$ & 0,44 & 0,05 & 0,08 & 0,02 & 0,06 & 0,01 & 0,05 & 0,62 & 0,14 & 0,06 \\
\hline $\mathrm{Sm}_{2} \mathrm{O}_{3}$ & 0,22 & 0,09 & 0,00 & 0,17 & 0,02 & 0,09 & 0,00 & 0,32 & 0,08 & 0,01 \\
\hline $\mathrm{Eu}_{2} \mathrm{O}_{3}$ & 0,00 & 0,00 & 0,00 & 0,00 & 0,00 & 0,06 & 0,00 & 0,00 & 0,00 & 0,00 \\
\hline $\mathrm{Gd}_{2} \mathrm{O}_{3}$ & 0,47 & 0,18 & 0,04 & 0,14 & 0,21 & 0,10 & 0,08 & 0,52 & 0,50 & 0,07 \\
\hline $\mathrm{Tb}_{2} \mathrm{O}_{3}$ & 0,12 & 0,00 & 0,00 & 0,00 & 0,00 & 0,00 & 0,00 & 0,00 & 0,00 & 0,00 \\
\hline $\mathrm{Dy}_{2} \mathrm{O}_{3}$ & 1,34 & 0,97 & 0,88 & 1,07 & 0,89 & 0,92 & 0,72 & 0,61 & 1,88 & 0,38 \\
\hline $\mathrm{Ho}_{2} \mathrm{O}_{3}$ & 0,43 & 0,37 & 0,38 & 0,43 & 0,59 & 0,26 & 0,28 & 0,08 & 0,47 & 0,17 \\
\hline $\mathrm{Er}_{2} \mathrm{O}_{3}$ & 1,64 & 1,45 & 1,09 & 1,39 & 1,32 & 1,10 & 0,89 & 0,62 & 2,29 & 0,41 \\
\hline $\mathrm{Tm}_{2} \mathrm{O}_{3}$ & 0,31 & 0,27 & 0,29 & 0,22 & 0,19 & 0,13 & 0,13 & 0,10 & 0,38 & 0,09 \\
\hline $\mathrm{Yb}_{2} \mathrm{O}_{3}$ & 2,80 & 1,77 & 1,85 & 2,35 & 1,48 & 1,87 & 1,42 & 0,56 & 3,32 & 0,86 \\
\hline $\mathrm{Lu}_{2} \mathrm{O}_{3}$ & 0,59 & 0,33 & 0,27 & 0,47 & 0,18 & 0,24 & 0,17 & 0,08 & 0,53 & 0,19 \\
\hline $\mathrm{UO}_{2}$ & 0,65 & 2,04 & 3,85 & 2,05 & 1,76 & 1,18 & 1,07 & 0,53 & 1,11 & 0,49 \\
\hline $\mathrm{ThO}_{2}$ & 32,77 & 17,92 & 21,70 & 20,16 & 25,00 & 11,99 & 14,52 & 9,16 & 19,07 & 11,59 \\
\hline $\mathbf{F}$ & 1,06 & 1,22 & 1,00 & 1,46 & 1,94 & 1,64 & 1,35 & 0,95 & 4,22 & 1,29 \\
\hline $\mathrm{F}=\mathrm{O}_{2}$ & 0,45 & 0,51 & 0,42 & 0,62 & 0,82 & 0,69 & 0,57 & 0,40 & 1,78 & 0,54 \\
\hline Total & 78,86 & 83,60 & 87,38 & 85,15 & 80,33 & 80,18 & 76,23 & 83,76 & 92,31 & 72,56 \\
\hline$R E E+Y$ & 22,49 & 12,16 & 12,03 & 13,80 & 15,05 & 11,30 & 10,18 & 12,25 & 24,00 & 8,92 \\
\hline LREE & 4,32 & 0,53 & 0,45 & 0,52 & 0,53 & 0,47 & 0,33 & 3,25 & 2,24 & 0,27 \\
\hline HREE & 18,17 & 11,63 & 11,58 & 13,28 & 14,53 & 10,83 & 9,85 & 9,00 & 21,76 & 8,65 \\
\hline \multicolumn{11}{|c|}{ Formula estructural calculada com base em 16 oxigênios } \\
\hline $\mathbf{P}$ & 0,130 & 1,081 & 1,082 & 0,996 & 1,149 & 0,917 & 1,086 & 0,265 & 0,613 & 1,031 \\
\hline $\mathrm{Nb}$ & 0,061 & 0,063 & 0,088 & 0,049 & 0,109 & 0,064 & 0,085 & 0,051 & 0,022 & 0,053 \\
\hline Si & 3,448 & 2,481 & 2,436 & 2,539 & 2,385 & 2,757 & 2,495 & 3,522 & 4,409 & 2,547 \\
\hline $\mathrm{Zr}$ & 0,288 & 1,832 & 1,672 & 1,698 & 1,246 & 2,221 & 1,969 & 2,306 & 0,661 & 2,131 \\
\hline $\mathrm{Ti}$ & 0,044 & 0,044 & 0,057 & 0,129 & 0,000 & 0,060 & 0,068 & 0,064 & 0,008 & 0,059 \\
\hline Al & 0,303 & 0,901 & 0,924 & 0,913 & 0,768 & 0,730 & 0,980 & 0,726 & 0,180 & 0,637 \\
\hline $\mathbf{Y}$ & 0,658 & 0,287 & 0,305 & 0,331 & 0,501 & 0,283 & 0,297 & 0,274 & 0,504 & 0,328 \\
\hline $\mathrm{Fe}$ & 0,348 & 0,120 & 0,099 & 0,077 & 0,069 & 0,121 & 0,083 & 0,272 & 0,022 & 0,506 \\
\hline $\mathrm{Ca}$ & 0,230 & 0,079 & 0,020 & 0,042 & 0,000 & 0,012 & 0,000 & 0,087 & 0,071 & 0,063 \\
\hline La & 0,006 & 0,000 & 0,000 & 0,000 & 0,001 & 0,002 & 0,001 & 0,003 & 0,005 & 0,000 \\
\hline $\mathrm{Ce}$ & 0,302 & 0,023 & 0,022 & 0,021 & 0,027 & 0,016 & 0,016 & 0,125 & 0,104 & 0,014 \\
\hline $\mathrm{Pr}$ & 0,008 & 0,001 & 0,000 & 0,000 & 0,004 & 0,001 & 0,001 & 0,007 & 0,004 & 0,000 \\
\hline Nd & 0,037 & 0,003 & 0,005 & 0,001 & 0,004 & 0,001 & 0,003 & 0,035 & 0,008 & 0,004 \\
\hline Sm & 0,018 & 0,005 & 0,000 & 0,010 & 0,001 & 0,005 & 0,000 & 0,017 & 0,004 & 0,001 \\
\hline Eu & 0,000 & 0,000 & 0,000 & 0,000 & 0,000 & 0,003 & 0,000 & 0,000 & 0,000 & 0,000 \\
\hline Gd & 0,036 & 0,010 & 0,002 & 0,008 & 0,014 & 0,006 & 0,005 & 0,027 & 0,025 & 0,004 \\
\hline Tb & 0,009 & 0,000 & 0,000 & 0,000 & 0,000 & 0,000 & 0,000 & 0,000 & 0,000 & 0,000 \\
\hline Dy & 0,101 & 0,054 & 0,048 & 0,059 & 0,056 & 0,051 & 0,042 & 0,031 & 0,093 & 0,023 \\
\hline Ho & 0,032 & 0,020 & 0,021 & 0,024 & 0,037 & 0,014 & 0,016 & 0,004 & 0,023 & 0,010 \\
\hline Er & 0,121 & 0,078 & 0,058 & 0,076 & 0,080 & 0,059 & 0,050 & 0,031 & 0,110 & 0,024 \\
\hline Tm & 0,023 & 0,014 & 0,015 & 0,012 & 0,012 & 0,007 & 0,007 & 0,005 & 0,018 & 0,006 \\
\hline $\mathrm{Yb}$ & 0,201 & 0,093 & 0,095 & 0,124 & 0,088 & 0,098 & 0,078 & 0,027 & 0,155 & 0,050 \\
\hline Lu & 0,042 & 0,017 & 0,014 & 0,024 & 0,010 & 0,013 & 0,009 & 0,004 & 0,025 & 0,011 \\
\hline $\mathbf{U}$ & 0,034 & 0,078 & 0,145 & 0,079 & 0,076 & 0,045 & 0,043 & 0,019 & 0,038 & 0,021 \\
\hline Th & 1,758 & 0,699 & 0,833 & 0,792 & 1,107 & 0,467 & 0,598 & 0,334 & 0,664 & 0,502 \\
\hline Total & 8,256 & 8,002 & 7,952 & 8,025 & 7,746 & 7,965 & 7,941 & 8,263 & 7,884 & 8,080 \\
\hline Thor & 43,402 & 19,418 & 24,597 & 21,691 & 30,556 & 12,855 & 16,142 & 8,534 & 17,803 & 12,940 \\
\hline Zircon & 6,986 & 45,796 & 42,039 & 42,319 & 32,173 & 55,759 & 49,583 & 55,812 & 16,779 & 52,761 \\
\hline Total & 53,530 & 92,232 & 93,854 & 88,823 & 92,383 & 91,649 & 93,077 & 70,751 & 50,126 & 91,231 \\
\hline
\end{tabular}


10.7 QUÍMICA MINERAL PARA ZIRCÃO

Zircões com ETR-Fácies PB1c

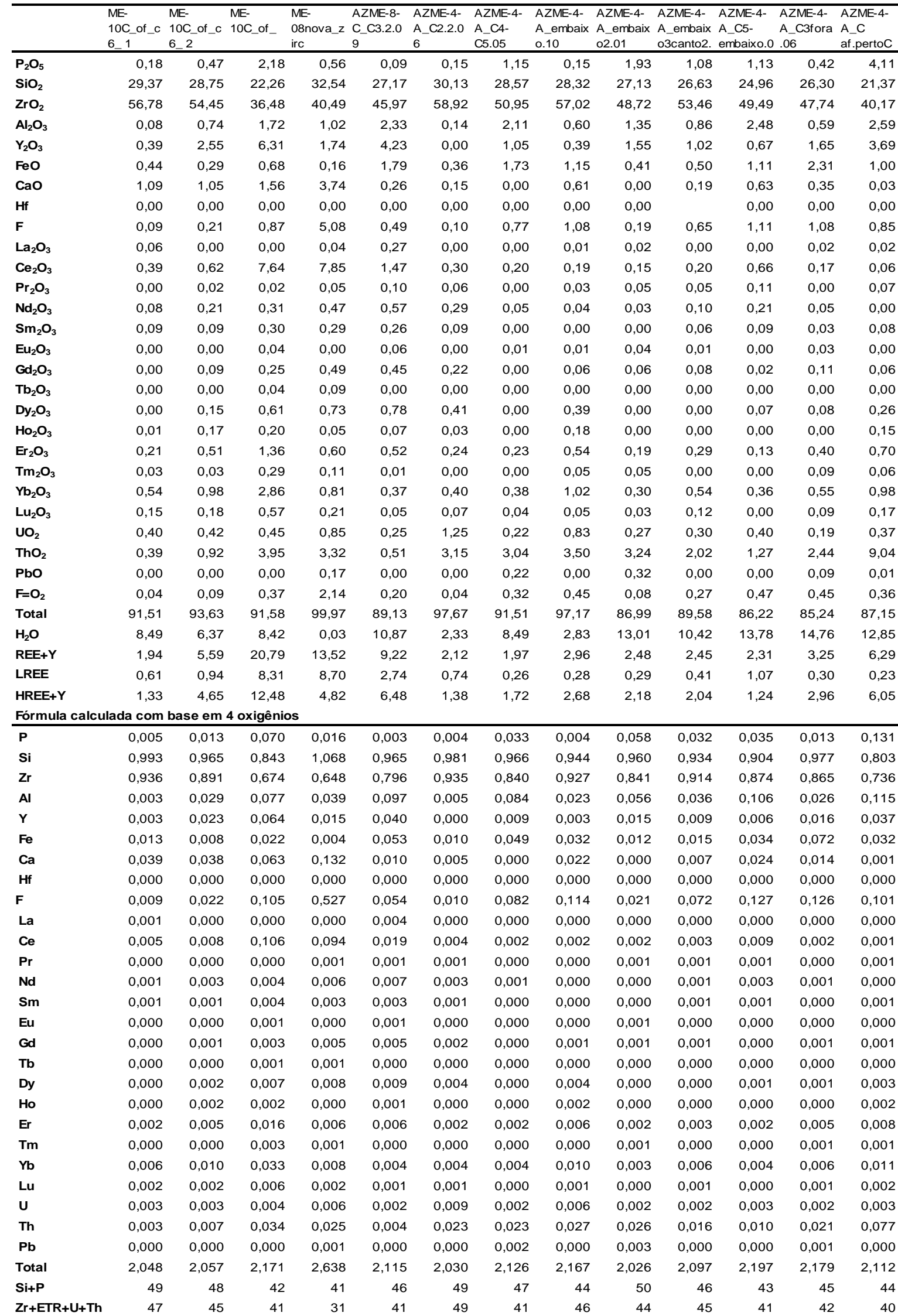




\section{CONTINUAÇÃO-ZIRCÃO}

Zircões com ETR-Fácies PB1c

\begin{tabular}{|c|c|c|c|c|c|c|c|c|c|c|c|c|}
\hline & $\begin{array}{l}\text { AZME- } \\
04 D- \\
\text { C5.1.03 }\end{array}$ & $\begin{array}{l}\text { AZME- } \\
04 D- \\
\text { C5.1.05 }\end{array}$ & $\begin{array}{l}\text { AZME- } \\
04 D- \\
\text { C5.2.07 }\end{array}$ & $\begin{array}{l}\text { AZME- } \\
04 B-C 1- \\
\text { C2.01 }\end{array}$ & $\begin{array}{l}\text { AZME- } \\
\text { 04B- } \\
\text { C4fora.1 }\end{array}$ & $\begin{array}{l}\text { AZME- } \\
\text { 04B- } \\
\text { C4fora.2 }\end{array}$ & $\begin{array}{l}\text { AZME- } \\
\text { 04B- } \\
\text { C4foraizq }\end{array}$ & $\begin{array}{l}\text { AZME- } \\
\text { 04B-C5.1 }\end{array}$ & $\begin{array}{l}\text { AZME- } \\
\text { 04B-C3.1 }\end{array}$ & $\begin{array}{l}\text { ME10C_C } \\
32\end{array}$ & $\begin{array}{l}\text { AZME4A_ } \\
\text { C6 } 2\end{array}$ & $\begin{array}{l}\text { AZME4A } \\
\text { C2 } 1\end{array}$ \\
\hline $\mathrm{P}_{2} \mathrm{O}_{5}$ & 0,38 & 0,20 & 0,35 & 1,57 & 0,49 & 0,78 & 0,56 & 0,10 & 0,27 & 0,12 & 0,80 & 0,61 \\
\hline $\mathrm{SiO}_{2}$ & 29,89 & 19,64 & 26,60 & 24,65 & 23,62 & 27,79 & 24,66 & 31,26 & 28,02 & 26,02 & 28,44 & 24,95 \\
\hline $\mathrm{ZrO}_{2}$ & 42,37 & 36,55 & 54,01 & 50,71 & 47,88 & 57,78 & 45,21 & 61,68 & 54,89 & 48,17 & 57,65 & 48,85 \\
\hline $\mathrm{Al}_{2} \mathrm{O}_{3}$ & 1,17 & 0,77 & 1,42 & 0,82 & 1,08 & 0,88 & 1,04 & 0,13 & 0,09 & 0,90 & 0,77 & 1,00 \\
\hline $\mathrm{Y}_{2} \mathrm{O}_{3}$ & 1,71 & 0,77 & 0,53 & 0,93 & 1,19 & 0,56 & 1,48 & 0,22 & 0,00 & 6,25 & 1,10 & 2,89 \\
\hline $\mathrm{FeO}$ & 0,22 & 1,02 & 1,53 & 0,36 & 0,33 & 0,51 & 0,47 & 0,01 & 0,46 & 0,58 & 0,86 & 0,70 \\
\hline $\mathrm{CaO}$ & 0,36 & 0,78 & 1,12 & 0,53 & 1,17 & 0,24 & 1,19 & 0,16 & 0,82 & 0,79 & 0,57 & 0,24 \\
\hline Hf & 0,00 & 0,00 & 0,00 & 0,00 & 0,00 & 0,00 & 0,00 & 0,00 & 0,00 & 2,05 & 2,24 & 1,53 \\
\hline $\mathbf{F}$ & 2,20 & 1,79 & 1,71 & 0,70 & 0,87 & 0,28 & 0,59 & 0,00 & 0,17 & 0,41 & 0,51 & 0,91 \\
\hline $\mathrm{La}_{2} \mathrm{O}_{3}$ & 0,03 & 0,02 & 0,06 & 0,00 & 0,04 & 0,01 & 0,01 & 0,02 & 0,09 & 0,07 & 0,00 & 0,04 \\
\hline $\mathrm{Ce}_{2} \mathrm{O}_{3}$ & 0,56 & 0,43 & 0,38 & 5,99 & 0,07 & 1,78 & 0,32 & 1,95 & 2,25 & 1,27 & 0,23 & 0,56 \\
\hline $\mathrm{Pr}_{2} \mathrm{O}_{3}$ & 0,02 & 0,05 & 0,00 & 0,08 & 0,00 & 0,05 & 0,02 & 0,02 & 0,08 & 0,05 & 0,04 & 0,10 \\
\hline $\mathrm{Nd}_{2} \mathrm{O}_{3}$ & 0,25 & 0,32 & 0,07 & 0,61 & 0,09 & 0,33 & 0,17 & 0,16 & 0,61 & 0,14 & 0,10 & 0,38 \\
\hline $\mathrm{Sm}_{2} \mathrm{O}_{3}$ & 0,11 & 0,09 & 0,00 & 0,15 & 0,02 & 0,01 & 0,00 & 0,09 & 0,21 & 0,02 & 0,15 & 0,10 \\
\hline $\mathrm{Eu}_{2} \mathrm{O}_{3}$ & 0,07 & 0,00 & 0,00 & 0,00 & 0,00 & 0,00 & 0,00 & 0,00 & 0,01 & 0,01 & 0,02 & 0,03 \\
\hline $\mathrm{Gd}_{2} \mathrm{O}_{3}$ & 0,24 & 0,17 & 0,13 & 0,15 & 0,09 & 0,12 & 0,00 & 0,04 & 0,14 & 0,20 & 0,13 & 0,25 \\
\hline $\mathrm{Tb}_{2} \mathrm{O}_{3}$ & 0,00 & 0,00 & 0,00 & 0,00 & 0,00 & 0,00 & 0,00 & 0,00 & 0,00 & 0,00 & 0,00 & 0,00 \\
\hline $\mathrm{Dy}_{2} \mathrm{O}_{3}$ & 0,27 & 0,03 & 0,25 & 0,00 & 0,00 & 0,00 & 0,01 & 0,00 & 0,00 & 0,58 & 0,19 & 0,22 \\
\hline $\mathrm{Ho}_{2} \mathrm{O}_{3}$ & 0,00 & 0,00 & 0,00 & 0,00 & 0,08 & 0,00 & 0,00 & 0,00 & 0,06 & 0,19 & 0,17 & 0,03 \\
\hline $\mathrm{Er}_{2} \mathrm{O}_{3}$ & 0,31 & 0,21 & 0,31 & 0,15 & 0,34 & 0,07 & 0,20 & 0,10 & 0,29 & 1,09 & 0,32 & 0,36 \\
\hline $\mathrm{Tm}_{2} \mathrm{O}_{3}$ & 0,06 & 0,00 & 0,00 & 0,00 & 0,07 & 0,02 & 0,01 & 0,00 & 0,00 & 0,24 & 0,03 & 0,03 \\
\hline $\mathrm{Yb}_{2} \mathrm{O}_{3}$ & 0,43 & 0,28 & 0,43 & 0,40 & 0,66 & 0,33 & 0,52 & 0,14 & 0,34 & 2,64 & 0,49 & 0,85 \\
\hline $\mathrm{Lu}_{2} \mathrm{O}_{3}$ & 0,04 & 0,09 & 0,09 & 0,00 & 0,16 & 0,00 & 0,09 & 0,00 & 0,00 & 0,45 & 0,14 & 0,04 \\
\hline $\mathrm{UO}_{2}$ & 1,00 & 0,61 & 0,94 & 0,13 & 2,11 & 0,28 & 0,63 & 0,12 & 0,86 & 0,23 & 0,26 & 1,48 \\
\hline $\mathrm{ThO}_{2}$ & 5,10 & 3,63 & 3,60 & 4,11 & 1,06 & 3,23 & 2,95 & 0,91 & 2,93 & 0,43 & 3,48 & 3,60 \\
\hline PbO & 0,50 & 0,99 & 0,55 & 0,56 & 3,23 & 1,25 & 1,20 & 0,22 & 1,44 & 0,00 & 0,03 & 0,00 \\
\hline $\mathrm{F}=\mathrm{O}_{2}$ & 0,93 & 0,75 & 0,72 & 0,29 & 0,37 & 0,12 & 0,25 & 0,00 & 0,07 & 0,17 & 0,21 & 0,38 \\
\hline Total & 87,04 & 91,72 & 94,52 & 93,58 & 85,64 & 97,61 & 82,66 & 98,05 & 94,96 & 94,06 & 100,02 & 90,43 \\
\hline $\mathrm{H}_{2} \mathrm{O}$ & 12,96 & 8,28 & 5,48 & 6,42 & 14,36 & 2,39 & 17,34 & 1,95 & 5,04 & 5,94 & 0,00 & 9,57 \\
\hline$R E E+Y$ & 4,07 & 2,45 & 2,26 & 8,44 & 2,79 & 3,27 & 2,81 & 2,76 & 4,07 & 13,21 & 3,10 & 5,88 \\
\hline LREE & 1,03 & 0,90 & 0,52 & 6,82 & 0,21 & 2,18 & 0,52 & 2,25 & 3,24 & 1,56 & 0,53 & 1,20 \\
\hline HREE+Y & 3,04 & 1,55 & 1,74 & 1,62 & 2,58 & 1,09 & 2,30 & 0,51 & 0,83 & 11,65 & 2,56 & 4,67 \\
\hline \multicolumn{13}{|c|}{ Fórmula calculada com base em 4 oxigênios } \\
\hline $\mathbf{P}$ & 0,012 & 0,006 & 0,010 & 0,047 & 0,016 & 0,022 & 0,018 & 0,003 & 0,008 & 0,004 & 0,022 & 0,019 \\
\hline Si & 1,082 & 0,670 & 0,917 & 0,875 & 0,913 & 0,919 & 0,953 & 0,992 & 0,961 & 0,917 & 0,919 & 0,913 \\
\hline $\mathrm{Zr}$ & 0,748 & 0,608 & 0,907 & 0,878 & 0,902 & 0,931 & 0,852 & 0,954 & 0,918 & 0,828 & 0,908 & 0,872 \\
\hline Al & 0,050 & 0,031 & 0,058 & 0,034 & 0,049 & 0,034 & 0,047 & 0,005 & 0,004 & 0,037 & 0,029 & 0,043 \\
\hline $\mathbf{Y}$ & 0,016 & 0,007 & 0,005 & 0,009 & 0,012 & 0,005 & 0,015 & 0,002 & 0,000 & 0,059 & 0,009 & 0,028 \\
\hline $\mathrm{Fe}$ & 0,007 & 0,029 & 0,044 & 0,011 & 0,011 & 0,014 & 0,015 & 0,000 & 0,013 & 0,017 & 0,023 & 0,022 \\
\hline $\mathrm{Ca}$ & 0,014 & 0,029 & 0,041 & 0,020 & 0,048 & 0,008 & 0,049 & 0,005 & 0,030 & 0,030 & 0,020 & 0,009 \\
\hline $\mathrm{Hf}$ & 0,000 & 0,000 & 0,000 & 0,000 & 0,000 & 0,000 & 0,000 & 0,000 & 0,000 & 0,021 & 0,021 & 0,016 \\
\hline $\mathbf{F}$ & 0,252 & 0,193 & 0,186 & 0,078 & 0,106 & 0,029 & 0,072 & 0,000 & 0,019 & 0,045 & 0,052 & 0,105 \\
\hline La & 0,000 & 0,000 & 0,001 & 0,000 & 0,001 & 0,000 & 0,000 & 0,000 & 0,001 & 0,001 & 0,000 & 0,001 \\
\hline $\mathrm{Ce}$ & 0,007 & 0,005 & 0,005 & 0,078 & 0,001 & 0,021 & 0,005 & 0,023 & 0,028 & 0,016 & 0,003 & 0,008 \\
\hline $\mathrm{Pr}$ & 0,000 & 0,001 & 0,000 & 0,001 & 0,000 & 0,001 & 0,000 & 0,000 & 0,001 & 0,001 & 0,000 & 0,001 \\
\hline Nd & 0,003 & 0,004 & 0,001 & 0,008 & 0,001 & 0,004 & 0,002 & 0,002 & 0,007 & 0,002 & 0,001 & 0,005 \\
\hline Sm & 0,001 & 0,001 & 0,000 & 0,002 & 0,000 & 0,000 & 0,000 & 0,001 & 0,002 & 0,000 & 0,002 & 0,001 \\
\hline $\mathrm{Eu}$ & 0,001 & 0,000 & 0,000 & 0,000 & 0,000 & 0,000 & 0,000 & 0,000 & 0,000 & 0,000 & 0,000 & 0,000 \\
\hline Gd & 0,003 & 0,002 & 0,001 & 0,002 & 0,001 & 0,001 & 0,000 & 0,000 & 0,002 & 0,002 & 0,001 & 0,003 \\
\hline $\mathrm{Tb}$ & 0,000 & 0,000 & 0,000 & 0,000 & 0,000 & 0,000 & 0,000 & 0,000 & 0,000 & 0,000 & 0,000 & 0,000 \\
\hline Dy & 0,003 & 0,000 & 0,003 & 0,000 & 0,000 & 0,000 & 0,000 & 0,000 & 0,000 & 0,007 & 0,002 & 0,003 \\
\hline Ho & 0,000 & 0,000 & 0,000 & 0,000 & 0,001 & 0,000 & 0,000 & 0,000 & 0,001 & 0,002 & 0,002 & 0,000 \\
\hline $\mathrm{Er}$ & 0,003 & 0,002 & 0,003 & 0,002 & 0,004 & 0,001 & 0,002 & 0,001 & 0,003 & 0,012 & 0,003 & 0,004 \\
\hline $\mathrm{Tm}$ & 0,001 & 0,000 & 0,000 & 0,000 & 0,001 & 0,000 & 0,000 & 0,000 & 0,000 & 0,003 & 0,000 & 0,000 \\
\hline $\mathrm{Yb}$ & 0,005 & 0,003 & 0,005 & 0,004 & 0,008 & 0,003 & 0,006 & 0,001 & 0,004 & 0,028 & 0,005 & 0,010 \\
\hline Lu & 0,000 & 0,001 & 0,001 & 0,000 & 0,002 & 0,000 & 0,001 & 0,000 & 0,000 & 0,005 & 0,001 & 0,000 \\
\hline $\mathbf{U}$ & 0,008 & 0,005 & 0,007 & 0,001 & 0,018 & 0,002 & 0,005 & 0,001 & 0,007 & 0,002 & 0,002 & 0,012 \\
\hline Th & 0,042 & 0,028 & 0,028 & 0,033 & 0,009 & 0,024 & 0,026 & 0,007 & 0,023 & 0,003 & 0,026 & 0,030 \\
\hline $\mathbf{P b}$ & 0,005 & 0,009 & 0,005 & 0,005 & 0,034 & 0,011 & 0,013 & 0,002 & 0,013 & 0,000 & 0,000 & 0,000 \\
\hline Total & 2,275 & 2,800 & 2,260 & 2,124 & 2,179 & 2,067 & 2,121 & 2,011 & 2,066 & 2,076 & 2,097 & 2,132 \\
\hline $\mathbf{S i + P}$ & 48 & 24 & 41 & 43 & 43 & 45 & 46 & 49 & 47 & 44 & 45 & 44 \\
\hline 8 & 37 & 24 & 13 & 48 & 45 & 48 & 43 & 49 & 49 & 44 & 46 & 45 \\
\hline
\end{tabular}




\section{CONTINUAÇÃO-ZIRCÃO}

Zircão puro-Fácies PB1

\begin{tabular}{|c|c|c|c|c|c|c|c|c|c|c|c|c|c|c|}
\hline & $\begin{array}{l}\text { AZME-8- } \\
\text { C_C1.2 }\end{array}$ & $\begin{array}{l}\text { AZME-8- } \\
\text { C_C1.2.1 }\end{array}$ & $\begin{array}{l}\text { AZME-8- } \\
\text { C_C3.1.0 } \\
4\end{array}$ & $\begin{array}{l}\text { AZME-4- } \\
\text { A_C2.2.0 } \\
4\end{array}$ & $\begin{array}{l}\text { AZME-4- } \\
\text { A_embaix } \\
\text { o.03 }\end{array}$ & $\begin{array}{l}\text { AZME-4- } \\
\text { A_embaix } \\
\text { o2.02 }\end{array}$ & $\begin{array}{l}\text { AZME- } \\
14 C- \\
\text { C8.1.03 } \\
\end{array}$ & $\begin{array}{l}\text { AZME- } \\
14 C- \\
C 1.1 .04 \\
\end{array}$ & $\begin{array}{l}\text { AZME- } \\
14 C- \\
C 4.2 .02 \\
\end{array}$ & $\begin{array}{l}\text { AZME- } \\
\text { 09A- } \\
\text { C2.1.01 } \\
\end{array}$ & $\begin{array}{l}\text { AZME- } \\
\text { 09A- } \\
\text { C2.3fora. }\end{array}$ & $\begin{array}{l}\text { AZME- } \\
09 A- \\
\text { C5.3.07 } \\
\end{array}$ & $\begin{array}{l}\text { AZME- } \\
\text { 04D- } \\
\text { C5.1.08 } \\
\end{array}$ & $\begin{array}{l}\text { AZME- } \\
\text { 04D- } \\
\text { C3foraizq } \\
\end{array}$ \\
\hline $\mathbf{P}_{2} \mathrm{O}_{5}$ & 0,06 & 0,15 & 0,07 & 0,15 & 0,20 & 0,14 & 0,34 & 0,55 & 0,24 & 0,13 & 0,50 & 0,13 & 0,13 & 0,26 \\
\hline $\mathrm{SiO}_{2}$ & 33,22 & 33,25 & 33,60 & 28,39 & 32,54 & 32,73 & 31,45 & 31,30 & 31,84 & 32,31 & 29,37 & 32,31 & 30,88 & 28,33 \\
\hline $\mathrm{ZrO}_{2}$ & 65,41 & 64,61 & 63,93 & 55,53 & 61,23 & 62,41 & 64,16 & 62,02 & 63,31 & 64,77 & 56,83 & 60,95 & 61,44 & 57,12 \\
\hline $\mathrm{Al}_{2} \mathrm{O}_{3}$ & 0,00 & 0,00 & 0,02 & 0,36 & 0,03 & 0,00 & 0,00 & 0,03 & 0,02 & 0,04 & 0,42 & 0,00 & 0,01 & 0,21 \\
\hline $\mathrm{Y}_{2} \mathrm{O}_{3}$ & 0,08 & 0,00 & 0,09 & 0,26 & 0,01 & 0,08 & 0,59 & 0,57 & 0,07 & 0,00 & 1,47 & 0,35 & 0,97 & 0,29 \\
\hline $\mathrm{FeO}$ & 0,34 & 0,30 & 0,18 & 1,28 & 0,10 & 0,09 & 0,20 & 0,47 & 0,11 & 0,03 & 0,35 & 0,17 & 0,20 & 0,37 \\
\hline $\mathrm{CaO}$ & 0,14 & 0,00 & 0,26 & 0,67 & 0,00 & 0,05 & 0,32 & 0,00 & 0,00 & 0,00 & 0,01 & 0,32 & 0,36 & 2,69 \\
\hline Hf & 0,00 & 0,00 & 0,00 & 0,00 & 0,00 & 0,00 & 0,00 & 0,00 & & 0,00 & 0,00 & 0,00 & 0,00 & 0,00 \\
\hline $\mathbf{F}$ & 0,00 & 0,00 & 0,00 & 0,96 & 0,00 & 0,00 & 0,00 & 0,00 & 0,00 & 0,00 & 0,05 & 0,00 & 0,38 & 2,36 \\
\hline $\mathrm{La}_{2} \mathrm{O}_{3}$ & 0,00 & 0,03 & 0,00 & 0,00 & 0,00 & 0,04 & 0,00 & 0,01 & 0,00 & 0,00 & 0,00 & 0,05 & 0,01 & 0,00 \\
\hline $\mathrm{Ce}_{2} \mathrm{O}_{3}$ & 0,03 & 0,11 & 0,01 & 0,07 & 0,07 & 0,03 & 0,03 & 0,04 & 0,04 & 0,00 & 0,13 & 0,03 & 0,04 & 0,23 \\
\hline $\mathrm{Pr}_{2} \mathrm{O}_{3}$ & 0,00 & 0,01 & 0,01 & 0,00 & 0,00 & 0,00 & 0,03 & 0,04 & 0,00 & 0,00 & 0,00 & 0,00 & 0,00 & 0,07 \\
\hline $\mathrm{Nd}_{2} \mathrm{O}_{3}$ & 0,00 & 0,00 & 0,00 & 0,03 & 0,02 & 0,00 & 0,00 & 0,02 & 0,02 & 0,02 & 0,01 & 0,03 & 0,01 & 0,14 \\
\hline $\mathrm{Sm}_{2} \mathrm{O}_{3}$ & 0,00 & 0,00 & 0,06 & 0,07 & 0,00 & 0,00 & 0,00 & 0,01 & 0,00 & 0,00 & 0,09 & 0,11 & 0,00 & 0,06 \\
\hline $\mathrm{Eu}_{2} \mathrm{O}_{3}$ & 0,00 & 0,00 & 0,06 & 0,03 & 0,03 & 0,00 & 0,00 & 0,00 & 0,00 & 0,00 & 0,00 & 0,03 & 0,02 & 0,00 \\
\hline $\mathrm{Gd}_{2} \mathrm{O}_{3}$ & 0,09 & 0,00 & 0,03 & 0,00 & 0,00 & 0,00 & 0,00 & 0,00 & 0,02 & 0,00 & 0,06 & 0,00 & 0,01 & 0,01 \\
\hline $\mathrm{Tb}_{2} \mathrm{O}_{3}$ & 0,00 & 0,00 & 0,00 & 0,00 & 0,00 & 0,00 & 0,00 & 0,00 & 0,00 & 0,00 & 0,00 & 0,00 & 0,00 & 0,00 \\
\hline $\mathrm{Dy}_{2} \mathrm{O}_{3}$ & 0,00 & 0,00 & 0,03 & 0,00 & 0,00 & 0,01 & 0,04 & 0,00 & 0,00 & 0,00 & 0,00 & 0,00 & 0,00 & 0,00 \\
\hline $\mathrm{Ho}_{2} \mathrm{O}_{3}$ & 0,12 & 0,07 & 0,00 & 0,00 & 0,11 & 0,00 & 0,00 & 0,00 & 0,00 & 0,09 & 0,00 & 0,00 & 0,04 & 0,00 \\
\hline $\mathrm{Er}_{2} \mathrm{O}_{3}$ & 0,00 & 0,03 & 0,06 & 0,07 & 0,07 & 0,03 & 0,09 & 0,06 & 0,08 & 0,00 & 0,09 & 0,02 & 0,13 & 0,09 \\
\hline $\mathrm{Tm}_{2} \mathrm{O}_{3}$ & 0,00 & 0,00 & 0,00 & 0,00 & 0,03 & 0,00 & 0,00 & 0,00 & 0,00 & 0,00 & 0,00 & 0,06 & 0,00 & 0,00 \\
\hline $\mathrm{Yb}_{2} \mathrm{O}_{3}$ & 0,00 & 0,00 & 0,03 & 0,21 & 0,00 & 0,05 & 0,08 & 0,00 & 0,08 & 0,01 & 0,15 & 0,05 & 0,18 & 0,13 \\
\hline $\mathrm{Lu}_{2} \mathrm{O}_{3}$ & 0,00 & 0,00 & 0,01 & 0,07 & 0,00 & 0,00 & 0,01 & 0,00 & 0,00 & 0,00 & 0,00 & 0,00 & 0,00 & 0,08 \\
\hline $\mathrm{UO}_{2}$ & 0,00 & 0,00 & 0,00 & 0,46 & 0,16 & 0,13 & 0,00 & 0,01 & 0,00 & 0,00 & 0,15 & 0,00 & 0,43 & 0,48 \\
\hline $\mathrm{ThO}_{2}$ & 0,01 & 0,00 & 0,00 & 0,21 & 0,07 & 0,01 & 0,06 & 0,04 & 0,00 & 0,02 & 0,13 & 0,01 & 0,24 & 0,38 \\
\hline PbO & 0,00 & 0,00 & 0,00 & 0,00 & 0,00 & 0,00 & 0,00 & 0,00 & 0,00 & 0,00 & 0,00 & 0,00 & 0,00 & 0,00 \\
\hline $\mathrm{F}=\mathrm{O}_{2}$ & 0,00 & 0,00 & 0,00 & 0,40 & 0,00 & 0,00 & 0,00 & 0,00 & 0,00 & 0,00 & 0,02 & 0,00 & 0,16 & 0,99 \\
\hline Total & 100,19 & 99,08 & 99,02 & 91,06 & 95,31 & 96,50 & 97,95 & 95,90 & 96,57 & 97,94 & 90,49 & 95,29 & 95,81 & 93,34 \\
\hline $\mathrm{H}_{2} \mathrm{O}$ & 0,00 & 0,92 & 0,98 & 8,94 & 4,69 & 3,50 & 2,06 & 4,10 & 3,43 & 2,06 & 9,51 & 4,71 & 4,19 & 6,66 \\
\hline REE+Y & 0,31 & 0,25 & 0,38 & 0,80 & 0,33 & 0,24 & 0,85 & 0,75 & 0,30 & 0,11 & 2,02 & 0,72 & 1,43 & 1,11 \\
\hline LREE & 0,03 & 0,14 & 0,14 & 0,20 & 0,12 & 0,08 & 0,05 & 0,13 & 0,06 & 0,02 & 0,24 & 0,24 & 0,09 & 0,50 \\
\hline HREE+Y & 0,28 & 0,11 & 0,24 & 0,60 & 0,21 & 0,17 & 0,80 & 0,62 & 0,24 & 0,09 & 1,78 & 0,49 & 1,34 & 0,61 \\
\hline \multicolumn{15}{|c|}{ Fórmula calculada com base em 4 oxigênios } \\
\hline $\mathbf{P}$ & 0,002 & 0,004 & 0,002 & 0,004 & 0,005 & 0,004 & 0,009 & 0,015 & 0,006 & 0,003 & 0,014 & 0,003 & 0,004 & 0,007 \\
\hline Si & 1,010 & 1,017 & 1,027 & 0,972 & 1,031 & 1,026 & 0,984 & 0,994 & 1,004 & 1,004 & 0,991 & 1,026 & 0,994 & 0,957 \\
\hline $\mathrm{Zr}$ & 0,970 & 0,964 & 0,953 & 0,927 & 0,946 & 0,954 & 0,979 & 0,960 & 0,973 & 0,981 & 0,935 & 0,943 & 0,965 & 0,941 \\
\hline Al & 0,000 & 0,000 & 0,001 & 0,015 & 0,001 & 0,000 & 0,000 & 0,001 & 0,001 & 0,001 & 0,017 & 0,000 & 0,001 & 0,008 \\
\hline $\mathbf{Y}$ & 0,001 & 0,000 & 0,001 & 0,002 & 0,000 & 0,001 & 0,005 & 0,005 & 0,001 & 0,000 & 0,013 & 0,003 & 0,008 & 0,003 \\
\hline $\mathrm{Fe}$ & 0,009 & 0,008 & 0,005 & 0,037 & 0,003 & 0,002 & 0,005 & 0,012 & 0,003 & 0,001 & 0,010 & 0,004 & 0,005 & 0,011 \\
\hline $\mathrm{Ca}$ & 0,004 & 0,000 & 0,008 & 0,025 & 0,000 & 0,002 & 0,011 & 0,000 & 0,000 & 0,000 & 0,000 & 0,011 & 0,012 & 0,097 \\
\hline $\mathbf{H f}$ & 0,000 & 0,000 & 0,000 & 0,000 & 0,000 & 0,000 & 0,000 & 0,000 & 0,000 & 0,000 & 0,000 & 0,000 & 0,000 & 0,000 \\
\hline $\mathbf{F}$ & 0,000 & 0,000 & 0,000 & 0,104 & 0,000 & 0,000 & 0,000 & 0,000 & 0,000 & 0,000 & 0,005 & 0,000 & 0,038 & 0,252 \\
\hline La & 0,000 & 0,000 & 0,000 & 0,000 & 0,000 & 0,001 & 0,000 & 0,000 & 0,000 & 0,000 & 0,000 & 0,001 & 0,000 & 0,000 \\
\hline $\mathrm{Ce}$ & 0,000 & 0,001 & 0,000 & 0,001 & 0,001 & 0,000 & 0,000 & 0,000 & 0,000 & 0,000 & 0,002 & 0,000 & 0,001 & 0,003 \\
\hline Pr & 0,000 & 0,000 & 0,000 & 0,000 & 0,000 & 0,000 & 0,000 & 0,000 & 0,000 & 0,000 & 0,000 & 0,000 & 0,000 & 0,001 \\
\hline Nd & 0,000 & 0,000 & 0,000 & 0,000 & 0,000 & 0,000 & 0,000 & 0,000 & 0,000 & 0,000 & 0,000 & 0,000 & 0,000 & 0,002 \\
\hline $\mathrm{Sm}$ & 0,000 & 0,000 & 0,001 & 0,001 & 0,000 & 0,000 & 0,000 & 0,000 & 0,000 & 0,000 & 0,001 & 0,001 & 0,000 & 0,001 \\
\hline Eu & 0,000 & 0,000 & 0,001 & 0,000 & 0,000 & 0,000 & 0,000 & 0,000 & 0,000 & 0,000 & 0,000 & 0,000 & 0,000 & 0,000 \\
\hline Gd & 0,001 & 0,000 & 0,000 & 0,000 & 0,000 & 0,000 & 0,000 & 0,000 & 0,000 & 0,000 & 0,001 & 0,000 & 0,000 & 0,000 \\
\hline Tb & 0,000 & 0,000 & 0,000 & 0,000 & 0,000 & 0,000 & 0,000 & 0,000 & 0,000 & 0,000 & 0,000 & 0,000 & 0,000 & 0,000 \\
\hline Dy & 0,000 & 0,000 & 0,000 & 0,000 & 0,000 & 0,000 & 0,000 & 0,000 & 0,000 & 0,000 & 0,000 & 0,000 & 0,000 & 0,000 \\
\hline Ho & 0,001 & 0,001 & 0,000 & 0,000 & 0,001 & 0,000 & 0,000 & 0,000 & 0,000 & 0,001 & 0,000 & 0,000 & 0,000 & 0,000 \\
\hline $\mathrm{Er}$ & 0,000 & 0,000 & 0,001 & 0,001 & 0,001 & 0,000 & 0,001 & 0,001 & 0,001 & 0,000 & 0,001 & 0,000 & 0,001 & 0,001 \\
\hline $\mathrm{Tm}$ & 0,000 & 0,000 & 0,000 & 0,000 & 0,000 & 0,000 & 0,000 & 0,000 & 0,000 & 0,000 & 0,000 & 0,001 & 0,000 & 0,000 \\
\hline $\mathrm{Yb}$ & 0,000 & 0,000 & 0,000 & 0,002 & 0,000 & 0,001 & 0,001 & 0,000 & 0,001 & 0,000 & 0,002 & 0,000 & 0,002 & 0,001 \\
\hline Lu & 0,000 & 0,000 & 0,000 & 0,001 & 0,000 & 0,000 & 0,000 & 0,000 & 0,000 & 0,000 & 0,000 & 0,000 & 0,000 & 0,001 \\
\hline $\mathbf{U}$ & 0,000 & 0,000 & 0,000 & 0,004 & 0,001 & 0,001 & 0,000 & 0,000 & 0,000 & 0,000 & 0,001 & 0,000 & 0,003 & 0,004 \\
\hline Th & 0,000 & 0,000 & 0,000 & 0,002 & 0,000 & 0,000 & 0,000 & 0,000 & 0,000 & 0,000 & 0,001 & 0,000 & 0,002 & 0,003 \\
\hline $\mathrm{Pb}$ & 0,000 & 0,000 & 0,000 & 0,000 & 0,000 & 0,000 & 0,000 & 0,000 & 0,000 & 0,000 & 0,000 & 0,000 & 0,000 & 0,000 \\
\hline Total & 2,010 & 2,004 & 2,008 & 2,164 & 2,003 & 2,002 & 2,009 & 2,003 & 2,003 & 2,004 & 2,007 & 2,005 & 2,045 & 2,313 \\
\hline Si & 50 & 51 & 51 & 45 & 51 & 51 & 49 & 50 & 50 & 50 & 49 & 51 & 49 & 41 \\
\hline $\mathrm{Zr}$ & 48 & 48 & 47 & 43 & 47 & 48 & 49 & 48 & 49 & 49 & 47 & 47 & 47 & 41 \\
\hline
\end{tabular}




\subsection{QUÍMICA MINERAL PARA APATITA}

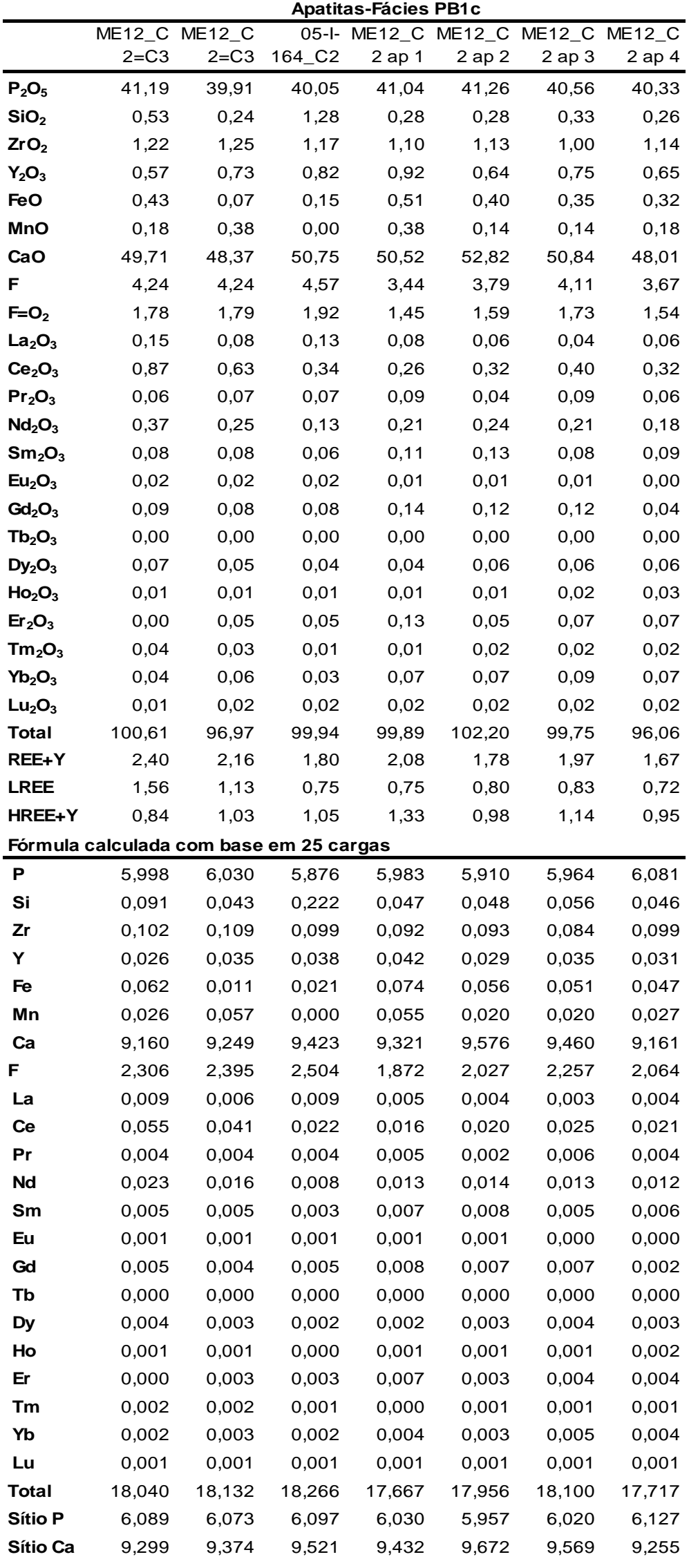




\subsection{QUÍMICA MINERAL PARA MINERAL NÃO IDENTIFICADO}

Mineral não identificado-Fácies PB1c

ME-10A- ME-10A- ME-10A- ME-10A- ME-10A- ME-10A- ME-10A- ME-10A- ME10A ME10A c6_4.1 c6_4.2 c6_4.3 c6_2 c6_3 c7A_1_1 c7A_1_2 c7A_2 C2 2 C2 4

\begin{tabular}{|c|c|c|c|c|c|c|c|c|c|c|}
\hline $\mathbf{P}_{2} \mathbf{O}_{5}$ & 0,00 & 0,00 & 0,00 & 0,06 & 0,00 & 0,00 & 0,00 & 0,00 & 0,08 & 0,00 \\
\hline $\mathrm{Nb}_{2} \mathrm{O}_{5}$ & 23,45 & 25,07 & 20,02 & 11,49 & 19,02 & 20,29 & 22,09 & 20,35 & 14,22 & 17,06 \\
\hline $\mathrm{Ta}_{2} \mathrm{O}_{5}$ & 1,89 & 1,25 & 1,58 & 0,58 & 1,49 & 1,41 & 1,62 & 1,22 & 1,55 & 3,29 \\
\hline $\mathrm{SiO}_{2}$ & 12,77 & 10,67 & 11,12 & 16,34 & 14,89 & 11,16 & 13,23 & 12,59 & 19,10 & 16,85 \\
\hline $\mathrm{ZrO}_{2}$ & 0,40 & 0,34 & 0,22 & 0,56 & 1,14 & 1,12 & 1,07 & 0,89 & 1,59 & 1,64 \\
\hline $\mathrm{TiO}_{2}$ & 1,63 & 3,06 & 2,39 & 2,70 & 3,10 & 0,47 & 0,92 & 0,72 & 5,10 & 6,17 \\
\hline $\mathrm{Al}_{2} \mathrm{O}_{3}$ & 1,43 & 1,29 & 1,34 & 2,15 & 2,44 & 1,59 & 1,58 & 1,63 & 2,51 & 1,41 \\
\hline $\mathbf{Y}_{2} \mathbf{O}_{3}$ & 8,67 & 8,69 & 8,09 & 5,54 & 8,67 & 6,04 & 6,97 & 6,54 & 5,40 & 7,10 \\
\hline $\mathrm{FeO}$ & 7,86 & 7,39 & 13,88 & 17,98 & 5,25 & 4,23 & 4,31 & 4,20 & 13,51 & 2,66 \\
\hline MnO & 0,04 & 0,08 & 0,20 & 0,23 & 0,23 & 0,31 & 0,19 & 0,15 & 0,09 & 0,03 \\
\hline $\mathrm{CaO}$ & 0,31 & 0,49 & 0,57 & 0,52 & 0,62 & 0,79 & 0,39 & 0,33 & 1,35 & 1,71 \\
\hline $\mathrm{BaO}$ & 0,06 & 0,06 & 0,06 & 0,00 & 0,02 & 0,04 & 0,05 & 0,04 & 0,02 & 0,06 \\
\hline SrO & 0,10 & 0,04 & 0,07 & 0,00 & 0,02 & 0,03 & 0,03 & 0,00 & 0,00 & 0,09 \\
\hline $\mathrm{Na}_{2} \mathrm{O}$ & 1,18 & 1,24 & 1,19 & 0,90 & 0,68 & 0,28 & 0,32 & 0,22 & 0,46 & 0,17 \\
\hline $\mathrm{K}_{2} \mathrm{O}$ & 0,27 & 0,34 & 0,18 & 0,65 & 0,44 & 0,47 & 0,20 & 0,20 & 0,64 & 0,20 \\
\hline Hf & 0,00 & 0,00 & 0,00 & 0,00 & 0,00 & 0,00 & 0,00 & 0,00 & 0,00 & 0,26 \\
\hline $\mathbf{F}$ & 0,36 & 0,44 & 0,41 & 0,34 & 0,68 & 0,66 & 0,58 & 0,83 & 0,29 & 0,46 \\
\hline $\mathrm{La}_{2} \mathrm{O}_{3}$ & 1,78 & 1,47 & 1,70 & 0,85 & 1,37 & 1,54 & 1,67 & 1,63 & 1,40 & 2,16 \\
\hline $\mathrm{Ce}_{2} \mathrm{O}_{3}$ & 5,81 & 5,76 & 5,10 & 4,31 & 6,06 & 15,34 & 13,42 & 17,03 & 4,17 & 6,94 \\
\hline $\mathrm{Pr}_{2} \mathrm{O}_{3}$ & 0,43 & 0,37 & 0,34 & 0,23 & 0,22 & 0,33 & 0,43 & 0,38 & 0,39 & 0,51 \\
\hline $\mathrm{Nd}_{2} \mathrm{O}_{3}$ & 1,48 & 1,72 & 1,59 & 1,24 & 1,24 & 1,26 & 1,17 & 1,25 & 1,09 & 1,62 \\
\hline $\mathrm{Sm}_{2} \mathrm{O}_{3}$ & 0,55 & 0,60 & 0,71 & 0,40 & 0,46 & 0,38 & 0,34 & 0,38 & 0,40 & 0,48 \\
\hline $\mathrm{Eu}_{2} \mathrm{O}_{3}$ & 0,00 & 0,00 & 0,00 & 0,00 & 0,00 & 0,00 & 0,00 & 0,00 & 0,09 & 0,09 \\
\hline $\mathrm{Gd}_{2} \mathrm{O}_{3}$ & 0,79 & 1,01 & 0,85 & 0,80 & 0,59 & 0,67 & 0,51 & 0,64 & 0,42 & 0,64 \\
\hline $\mathrm{Tb}_{2} \mathrm{O}_{3}$ & 0,19 & 0,18 & 0,17 & 0,21 & 0,20 & 0,12 & 0,12 & 0,22 & 0,00 & 0,00 \\
\hline $\mathrm{Dy}_{2} \mathrm{O}_{3}$ & 1,99 & 2,43 & 2,21 & 2,01 & 1,54 & 1,70 & 1,35 & 1,36 & 1,03 & 1,86 \\
\hline $\mathrm{Ho}_{2} \mathrm{O}_{3}$ & 0,74 & 0,46 & 0,74 & 0,39 & 0,51 & 0,17 & 0,47 & 0,48 & 0,61 & 0,40 \\
\hline $\mathrm{Er}_{2} \mathrm{O}_{3}$ & 2,24 & 2,16 & 2,03 & 1,92 & 1,88 & 1,71 & 1,65 & 1,74 & 1,34 & 1,84 \\
\hline $\mathrm{Tm}_{2} \mathrm{O}_{3}$ & 0,38 & 0,47 & 0,48 & 0,40 & 0,24 & 0,25 & 0,38 & 0,36 & 0,27 & 0,45 \\
\hline $\mathrm{Yb}_{2} \mathrm{O}_{3}$ & 3,10 & 3,14 & 3,00 & 2,15 & 2,56 & 2,54 & 2,39 & 2,61 & 2,10 & 2,93 \\
\hline $\mathrm{Lu}_{2} \mathrm{O}_{3}$ & 0,65 & 0,59 & 0,52 & 0,44 & 0,61 & 0,51 & 0,31 & 0,54 & 0,37 & 0,53 \\
\hline $\mathrm{UO}_{2}$ & 4,88 & 4,55 & 4,98 & 2,79 & 3,83 & 4,04 & 3,39 & 4,07 & 2,43 & 3,83 \\
\hline $\mathrm{ThO}_{2}$ & 0,90 & 0,89 & 0,89 & 2,13 & 1,57 & 2,15 & 1,78 & 1,72 & 0,97 & 0,47 \\
\hline $\mathrm{PbO}$ & 2,10 & 1,17 & 1,83 & 0,56 & 1,08 & 3,04 & 2,56 & 3,16 & 1,44 & 1,47 \\
\hline $\mathrm{F}=\mathrm{O}_{2}$ & 0,15 & 0,18 & 0,17 & 0,14 & 0,29 & 0,28 & 0,24 & 0,35 & 0,12 & 0,19 \\
\hline Total & 88,28 & 87,18 & 88,27 & 80,70 & 82,39 & 84,35 & 85,22 & 87,11 & 84,28 & 85,20 \\
\hline REE+Y & 28,81 & 29,02 & 27,53 & 20,87 & 26,17 & 32,55 & 31,17 & 35,16 & 19,07 & 27,56 \\
\hline LREE & 10,06 & 9,91 & 9,44 & 7,02 & 9,36 & 18,84 & 17,03 & 20,66 & 7,53 & 11,80 \\
\hline HREE+Y & 18,75 & 19,11 & 18,09 & 13,85 & 16,81 & 13,72 & 14,14 & 14,49 & 11,54 & 15,76 \\
\hline
\end{tabular}




\section{CONTINUAÇÃO-MINERAL NÃO IDENTIFICADO}

Mineral não identificado-Fácies PB1c

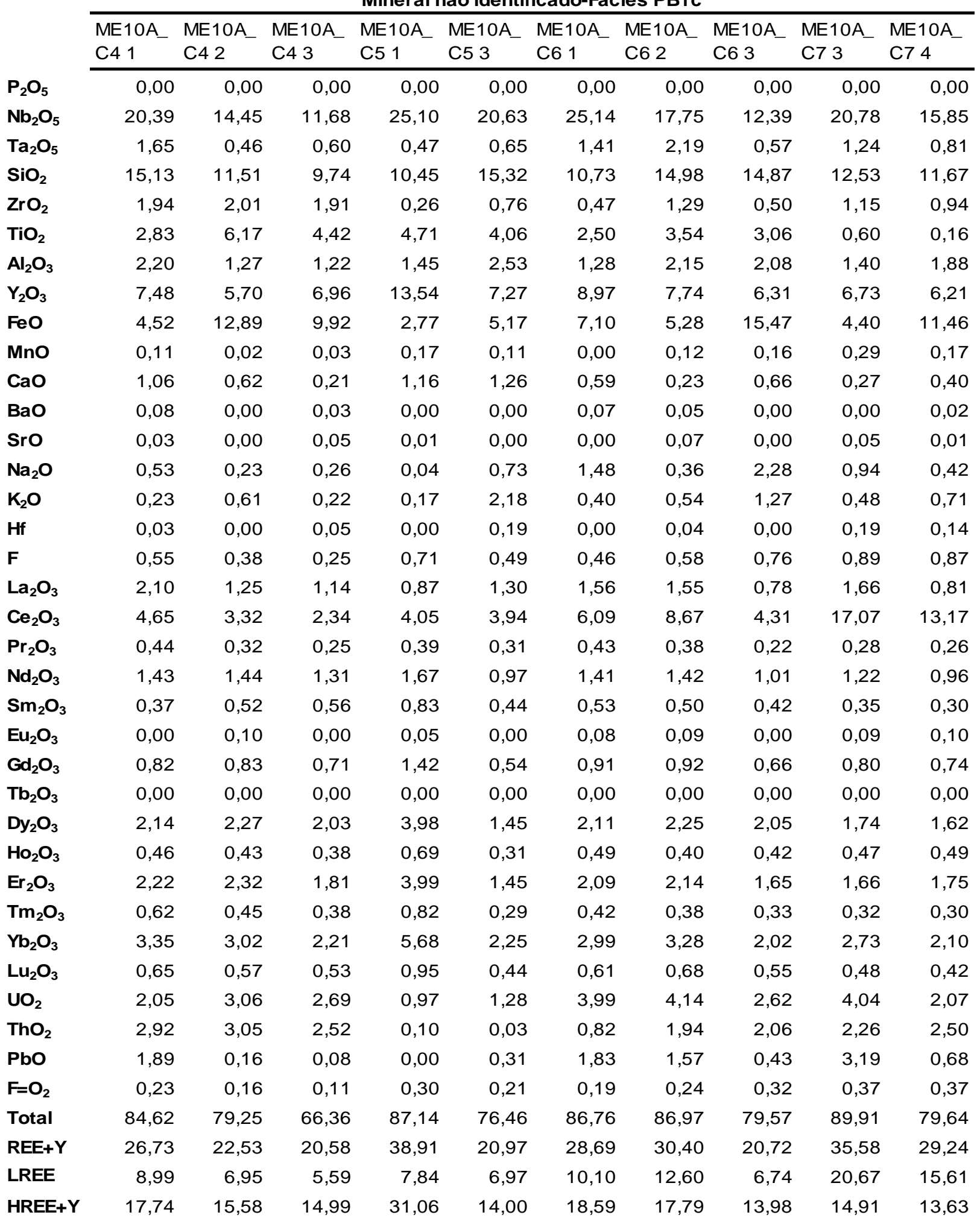

